\title{
The Idea of a Citizen: The Role of Higher Education Institutions in the Development of Citizens and an Exploration of Innovative Teaching Techniques to Aid in the Process
}

Eric Matthew Myers

West Virginia University, eric.myers@mail.wvu.edu

Follow this and additional works at: https://researchrepository.wvu.edu/etd

Part of the American Politics Commons, and the Other Political Science Commons

\section{Recommended Citation}

Myers, Eric Matthew, "The Idea of a Citizen: The Role of Higher Education Institutions in the Development of Citizens and an Exploration of Innovative Teaching Techniques to Aid in the Process" (2020). Graduate Theses, Dissertations, and Problem Reports. 7763.

https://researchrepository.wvu.edu/etd/7763

This Dissertation is protected by copyright and/or related rights. It has been brought to you by the The Research Repository @ WVU with permission from the rights-holder(s). You are free to use this Dissertation in any way that is permitted by the copyright and related rights legislation that applies to your use. For other uses you must obtain permission from the rights-holder(s) directly, unless additional rights are indicated by a Creative Commons license in the record and/ or on the work itself. This Dissertation has been accepted for inclusion in WVU Graduate Theses, Dissertations, and Problem Reports collection by an authorized administrator of The Research Repository @ WVU.

For more information, please contact researchrepository@mail.wvu.edu. 
The Idea of a Citizen:

The Role of Higher Education Institutions in the Development of Citizens and an Exploration of Innovative Teaching Techniques to Aid in the Process

\author{
Eric Myers
}

\author{
Dissertation submitted \\ to the Eberly College of Arts and Sciences \\ at West Virginia University
}

in partial fulfillment of the requirements for the degree of

Doctor of Philosophy in
Political Science

Jeff Worsham, Ph.D., Chair

Erin Cassese, Ph.D., Co-Chair

Clarissa Estep, Ph.D.

Philip Michelbach, Ph.D.

Department of Political Science

Morgantown, West Virginia

2020

Keywords: citizen, service-learning, virtual reality, experiential education, social capital, empathy

Copyright 2020 Eric Myers 


\section{Abstract \\ The Idea of a Citizen: \\ The Role of Higher Education Institutions in the Development of Citizens and an Exploration of Innovative Teaching Techniques to Aid in the Process}

\section{Eric Myers}

This work seeks to explain how institutions of higher education and political science educators within those institutions can develop students into citizens. Understanding the role of each (institution, educator, and student) within American democracy is important and the focus of this research. As the roles of each are demarcated, it becomes clear that higher education institutions and their political science educators have a unique ability to nurture students into citizens with a strong sense of civic purpose and understanding.

The subsequent chapters in this work explore the use of experiential education and other innovative teaching methods to determine if students can be taught to be better citizens. Findings in those chapters suggest that traditional means of measuring engagement (i.e. social capital)

may display some change (i.e. political and civic engagement), while other areas remain stagnant (i.e. religious participation, informal social connections, and trust). Also, the inclusion of innovative teaching techniques, like virtual reality, do increase bridging and bonding social capital, as well as empathy. Additionally, student responses to the experiences does yield important results that suggests students do positively evaluate their experiential education experience. This research suggests that political science educators have the ability to impact a student's development as a citizen, but the educator must be willing to engage the student using methods not typically employed in classroom settings. 


\section{Table of Contents}

Chapter One

Introduction - Beginning to Understand the Problem of Citizen Development in Higher Education

Chapter Two

Theory and Application - Understanding the Role of Political Science Education in the Mission of Higher Education

Chapter Three

Mission Impossible? - Can Service-Learning and Professional Field Experience be Effectively Implemented by Institutions of Higher Education to Create Social Capital in Students?

Chapter Four

The Long Road Ahead - Is There Long-Term, Identifiable Development of Social Capital in Graduates Who Participated in Experiential Education?

Chapter Five

Integrating Virtual Reality in the Classroom: Bolstering Social Capital and Developing Empathy

Chapter Six

Continuing the Mission - Conclusions and Future Research

References:

Appendix A

Appendix B

Appendix $C$ 


\section{Chapter One: Introduction - Beginning to Understand the Problem of Citizen Development in Higher Education}

In my own experience, telling people that I am pursuing an advanced degree in political science is met with one of two reactions. The first is normally a confused stare, which I can only surmise is a mix of bewilderment about what I could possibly do with that degree or what political science truly is. The other reaction is that the individual immediately says something such as, "it's a mess, isn't it?" or "what do you think about this [insert any current event]?” It is my belief that both reactions stem from the same lack of understanding regarding the field. Whereas, political scientists use data and theory to predict or explain political circumstances, a lot of people think that we, as a profession, sit around and just talk about current events, or the antics of President Trump. This generalization of the field highlights why it is even more difficult to explain the role of a political science educator to the masses. Throughout the course of this research, I will highlight why it is imperative for political science educators to take on new and innovative teaching methods as we try to encourage student exploration of their own political values and beliefs. While traditional classroom instruction does have benefits, it is imperative for educators to see that more needs to be undertaken in order to truly engage students in thinking about and promoting democracy.

Using institutions of higher education as a laboratory of democracy makes sense because students are already primed to learn. Those students enter their undergraduate experience knowing that they will develop career-oriented skills; therefore, if students are already open to accepting new ideas, it makes logical sense that teaching them about their role in American democracy should not be difficult. Furthermore, the ties between the mission of these institutions and the development of the country's citizens will be addressed in more detail in Chapter Two, but suffice it to say that political science educators are presented with a unique opportunity to 
guide students towards becoming more engaged citizens. To ignore this opportunity would encumber civic education at one of the final opportunities available to those students. If institutions do not focus on civic education at this point, it is quite possible that students will matriculate into society without completely understanding their role in safeguarding American democracy.

Democracy Counts 2018, a report issued by the Institute for Democracy \& Higher Education at Tufts University, found that the rate at which college students voted increased from "19\% in 2014 to $40 \%$ in 2018 " (Thomas, et al. 2019, 3). As the report indicates, an increase was not particularly surprising, given that the "voting rates among all Americans increased 13.6[\%]" (3). Still, the drastic increase in participation among students is shockingly high, and this causes questions to be raised around the catalyst for such turnout. As Nancy Thomas, Director of the Institute for Democracy \& Higher Education, notes "institutions are...embracing political learning, discussion, and equity as year-round educational objectives for all students" (3). She goes onto suggest that it is important for all stakeholders to "be skilled in the arts of discussion of teaching, leadership, and participation" (3). Furthermore, the report concludes with a call for educators to "increase their understanding of promising practices... and replicate what works" (17). These observations are driving force behind the work presented in subsequent chapters. If we as educators want to strengthen and bolster democracy, we need to be prepared to adapt the manner in which we engage with students. Merely getting students to the ballot box is only one step in a litany of actions that need to occur for students to be fully engaged in democracy. Therefore, the idea of a citizen is harder to conceptualize than previously thought; this means it is even more imperative for political science educators to think outside the normal means of classroom education in order to fully engage students in democracy. 
In Andrew Peterson's (2011) book, Civic Republicanism and Civic Education: The Education of Citizens, he contends that "civic republicanism" is a preliminary goal that institutions, predominately through the use of its educators, seek to obtain as they create students who are civically inclined. This idea of civic republicanism will be discussed more in Chapter Two in regard to Morone's (1998) views on classical republicanism. However, it is important to note that the premise of the following research is predicated on the idea that institutions of higher education seek to instill in students a sense of civic responsibility that enables them to do things in pursuit of a common or greater good. While Morone contends that the soul of American polity centers around a struggle between a liberal and republican interpretation, institutions of higher education are clearly employing the republican view as they ask students to become more engaged in their communities, and hopefully within the larger context of American democracy. This is presented to students as part of their civic duty, though it often is masked as a course requirement.

Still, it is important to note that these institutions often find that they have a duty to produce citizens who are at least better attuned to their democratic responsibilities upon graduation. The rationale for that sense of duty is further explained in Chapter Two, but it centers around the notion of a university's mission, as perceived by the political class and members of the institution's governing body. However, achieving the end result of a student who has transformed into a more engaged citizen is often done through a variety of experiential education techniques, met with varying levels of success depending on how those techniques were implemented. In the course of the following research, service-learning, professional field experience, and immersive virtual reality are used to discern if student attitudes and perceptions regarding civic engagement change over the course of the semester. 
Chapter Two of this research focuses on the theory supporting civic education in institutions of higher education. The chapter beings with an explanation of why political science education needs to focus on citizen production and development. Understanding those ideas within the larger mission of higher education institutions is paramount. That mission suggests that institutions have a vested and inherent interest in producing and developing citizens able to participate in democracy. Therefore, the mission of the university will be explored. This chapter also explores the background of social capital and its relevance to the idea of a citizen. Focusing on Putnam's decades-long work on social capital provides the starting point for the discussion; however, this discussion will also detail if social capital is the right method for evaluating if and how citizens are participating in democracy. Finally, Chapter Two discusses the theoretical framework for using experiential education in higher education to promote students becoming civically engaged. The purpose of this chapter is to highlight the theoretical rationale behind the research in subsequent chapters.

Chapter Three details the need for colleges and universities to address the challenges and opportunities detailed in A Crucible Moment: College Learning \& Democracy's Future (2012). If the United States government has identified a role for these institutions, how can that role be achieved? This chapter focuses on the use of service-learning and professional field experience in order to develop social capital. Based on the work of Hunter and Brisbin (2000), Chapter Three illustrates that experiential education does have an impact on student attainment, especially in regard to civic duty; however, that impact does not play out exactly as anticipated. This chapter is intended to show how students develop over the course of the semester, but, as you will see in this section, development is evident, not in all forms of social capital attainment but especially in the students' perception of what they gained over the semester. 
Using the data collected in Chapter Three as a starting point, Chapter Four focuses on if students continue to develop civically once their experiential education has occurred. That is, will students who have matriculated from the university have higher social capital scores because of their experiential education? This chapter finds similar conclusions to those in Chapter Three. Students and graduates do not have statistically significant differences in their social capital scores in all traditionally measured variables, but they indicate in their responses that the experience had a profound impact on their understanding and learning of key theories and concepts. This chapter highlights why this is perhaps more important than higher social capital scores and why it is especially important to focus on new and innovative teaching techniques that engage students and equip them with the skills necessary to participate in democracy.

Chapter Five details the findings of using an innovative teaching technique in a political science course. Using virtual reality (VR) to supplement and enhance the student experience and understanding how that experience may lead to higher social capital and empathy is the main focus of this chapter. In light of the United Nations' push to develop empathy in its own delegates, faculty at West Virginia University integrated the use of VR into the classroom. It was the intent that students would be immersed in situations and settings that they would otherwise not be able to witness. For instance, students were able to join women and children who make as many as 8 trips a day to the nearest water source in order to sustain the lives of their families. Obviously, students would not normally experience this, so it is the intention of this research to highlight how students understand those outside of their normal in-groups. If students can understand the plight of others, it could potentially make them more likely to engage in offering solutions to address those plights. Moreover, this chapter makes it possible to understand that students may be more inclined to participate in democracy if they understand those who are not 
like them. This idea builds on the notion of classical republicanism suggested by Morone (1998) and discussed in Chapter Two.

All of the research in subsequent chapters implores those within higher education, specifically in political science education, to address citizen development. Chapter Six is intended to highlight the path forward in ensuring that student education does not forget to focus on civic education. Without students understanding their role in democracy, it is only a matter of time before there is a true crisis of democracy, specifically here in America. Chapter Six provides some initial framework for future research to build on educating our students to be an effective citizen. While Chapters Three, Four, and Five focused on the using various forms of innovative teaching techniques to engage students, Chapter Six will note that there are a multitude of ways to engage students. Only if stakeholders within institutions of higher education fail to realize the benefit citizen development, are we truly in danger of losing our democracy. However, if recent trends continue, it is possible that democracy is in danger of extinction. 


\section{Chapter Two: Theory and Application - Understanding the Role of Political Science Education in the Mission of Higher Education}

"We are challenged by the need to insure that higher education shall take its proper place in our national effort to strengthen democracy at home..."

- President Truman's Statement Making Public a Report of the Commission on Higher Education, December $15^{\text {th }}, 1947$

\section{$\underline{\text { Introduction }}$}

How does the United States government develop its own citizenry and to what effect is that development to occur? While there remains debate about the framers' original intent, at least in regard to the education of the nation's citizenry, there is less doubt about the current desire from educators and government officials to link democracy upkeep to institutions of higher education. This is evidenced by policy advocated by former Presidents George W. Bush and Barack Obama $^{1}$. As government endorsed research such as A Crucible Moment: College Learning \& Democracy's Future highlights, institutions of higher education are being asked to train students, not just in their areas of academic study, but also as informed and engaged citizen, by increasing their political knowledge and promoting their political and civic participation. Which brings up the question of how civic education should be taught. Related to this, is political science an effective means to cultivate and develop America's citizenry? An examination of political science education will provide the necessary understanding of why political science, not necessarily as a major or minor, but as an academic unit within an institution, provides some of the most fertile ground for exposing students to ideas of democracy as educators try to create a

\footnotetext{
${ }^{1}$ President Truman ordered a commission to report on the state of American higher education. This commission produced the Higher Education for American Democracy report. Truman contended that higher education was an important component for the development of the nation's citizenry. In 2002, President George W. Bush introduced history and civic education initiatives that spanned primary, secondary, and higher education. 65 years after the Truman Administration report, A Crucible Moment was released. A Crucible Moment, sanctioned by the Obama Administration, was touted as a roadmap for developing citizens of the $21^{\text {st }}$ century.
} 
better citizen. This discussion will then transfer to the overall mission of higher education institutions; specifically, what is the role of these institutions in producing citizens who are more engaged with their communities and in effect, their government?

It is necessary to identify the need and desire of institutions of higher education to help in democracy maintenance, but it is also important to understand how these institutions can monitor and gauge whether or not this development is taking place. As this chapter defines civic engagement and evaluates whether or not higher education has the means or need to develop citizens, methods of increasing social capital will be addressed.

Finally, it is crucial to address how social capital can be developed, especially since it the variable that is used to appraise whether or not students are becoming more engaged in their democracy. As a result of this, all three empirical chapters seek to identify if experiential education is a valid means to increase social capital. Experiential education needs to be defined, at least in regard to its use within this research, in order to illustrate how these types of education may lead to increased social capital. Krishna (2002) argues that as democracies have been established in Asia, Eastern Europe, and Latin America, "[s]ocial capital provides both glue and gear" and that higher social capital often lead to higher levels of participation in those democracies (457). While this research does promote the idea of developing social capital, it is important to note that agency capacity, or the ability of institutions to help affect positive change, is also a motivating factor that must be considered (Klesner 2007).

\section{Political Science: The What and Why?}

Former President Woodrow Wilson described political science as the "interpretation of life; its instrument is insight, a nice understanding of subtle, unformulated conditions" (Wilson $1925,195)$. Wilson's idea that political science is the interpretation of life is interesting because 
it suggests that the field should exam the behavioral attitudes and actions of people in the course of their life. This would seem to encompass many aspects outside of the "political" world. It is through this analysis that it becomes clear that political science should focus on more than just the political. In pursuit of that endeavor, the research in subsequent chapters will focus on items important to political scientists (i.e. voting behavior), but also important to the overall development of a citizen's life (i.e. social connections). However, if Wilson's commentary is considered, all of those areas should be important to the study of political science.

Additionally, while Wilson's comment seems to signify a consensus for the role of political science in America, the reality is not so easily identifiable as evidenced by the historical progression of the field over the last 300 years, at least here in the United States. As Gunnell (1993) illustrates, the role of the field has ebbed and flowed, often times focuses on political theory, sometimes on the education of bureaucrats, and yet at other times focusing on the development of public policy. His work demonstrates that there has been a constant battle regarding the role that political science should play in the American political arena and that the role continues to change as events shape American democracy. More importantly, Gunnell brings to light many interesting debates regarding political science, particularly the "disengagement of political science from substantive political issues and as a crisis in the university's relationship to public life" (17). From his analysis, it is possible to see that some scholars began to question the effectiveness of political science, if the focus was not somehow tied to policy outputs. If the goal of political science was merely a historical analysis of theories and writings, it was definitely succeeding in that arena; however, as he notes, the battle for the course of political science in higher education was far from settled.

The beginnings of American political science had its roots firmly within the realm of the 
social sciences. Gunnell documents many instances of history and political science being tied together in departments, often times reflecting the nature of using political theory to assess historical events and situations. Gunnell states "[s]ocial science in many of its basic dimensions began as a reform movement. Lacking political authority, it sought purchase in the authority of knowledge which in turn led to specialization, differentiation, and gravitation toward the university to ensure its claim to science" (23). This movement to focus specifically on the "science" behind phenomenon was a result of the difficulty of expressing the importance of viewing political science as a valuable endeavor to those within and outside of higher education institutions. Although the social science movement in America had its core foundation in higher education, those "roots were more practical than academic" (42). The need to convey the legitimacy of the field often lead to the "scientific" approach at the disadvantaged of the theory behind the science.

It is important to point out that much of American political science is developed based on ideas and notions promulgated from German universities. It was those institutions that began to move away from their religious ties and focus more on education that "would train a bureaucratic professional elite" (26). For reasons that are not completely clear, a large portion of the scholars that Gunnell discusses were educated within this German mindset. These philosophies would transfer across the ocean and help to develop the current state of political science within the U.S. and by the late 1800s, the focus of political science was on "prepar[ing] young men for the duties of public life" (51).

However, the evolution of American political science did not start and stop with the German model. Gunnell notes that as political science in America changed conceptions about the role it would play in describing American life, the ideas around what political science would 
focus on as a discipline did begin to solidify. Francis Lieber, the first "political scientist" as noted by the American National Biography, developed his research and implementation of what political science should be on the aforementioned German model. This model of producing bureaucrats leads Lieber to articulate his belief that political science education was a necessary field of study for all students "in a country where there was a great deal of liberty and political action" (30). The U.S. needed to educate those who were experiencing these freedoms so that it would be possible to safeguard those same freedoms. Gunnell contends that Lieber focus on the importance of political economy, ethics, the science of government and historical interpretations was necessary in order to truly engage the public with what was actually occurring in and around their everyday life. It is clear that the notion of interpreting life, as Wilson suggests, was becoming more and more the focus within the political science field.

Although the focus of political science may have initially started with the education of those intending to enter the public sphere, Gunnell suggests Woodrow Wilson thought that "the role of political science...was not to provide practical expertise but knowledge" (83). This expectation of knowledge saw the focus of political science change from developing practical application to developing knowledge of government and how things function. This knowledge would then translate into public policy through enacted law, thus building knowledge and having the additional benefit of better policy.

As the role of political science continued to evolve, political scientists like Charles Merriam Jr. sought to expand the role of political science into the public sphere. Merriam's goals were that "political science would aid in creating democratic citizens and in providing the basis of rational public policy" (88). Again, the creation of citizens would hopefully lead to better public policy. While that may not always have occurred, it became clear that the goal of political 
science was to "bridge the gulf between academic and public discourse without fundamentally transforming the scholarly enterprise and without directly entering the distasteful and dangerous world of partisan politics" (275). Yes, political science would educate those with knowledge of the system. Yes, that knowledge would translate into public policy. However, the motivation behind these endeavors would not be to explicitly enter into the battle over politics specifically. "The education of citizens and statesmen in the way of general political morality and the entailed rights and duties of American government was the goal" (34).

Whereas the education of men was predominately the focus of higher education, here in the U.S., the National Center for Education Statistics now projects that women will overwhelming outnumber men in both 2- and 4-year higher education institutions. This alleviates any concern that only males are receiving the type of citizenship building that will be discussed in the subsequent sections. Furthermore, an April 25, 2019 press release from the Bureau of Labor Statistics now projects that $69.1 \%$ of 2018 high school graduate were enrolled in institutions of higher education. This statistic alone signifies the important role that political science departments across the nation CAN play in the development of the country's citizenry.

This then presents an interesting situation for political scientists. If the goal of civic education is to form a more knowledgeable citizen, who will hopefully become more civically engaged, how can this information that is specific be transferred to the citizenry, especially those in undergraduate education? Metzger and Smetana (2010) note that "developing an understanding of government and of civic and political rights is essential to civic development" because it "lays the foundation for an appreciation of the relationship between the individual and civic institutions" (231). Political science may not be the only academic field of study that can be used to effectively produce citizens. While it seems intuitive for political science courses to 
discuss the importance of being a citizen, it is also possible to see how other forms of education may need to be used in order to experience the best results.

As students begin to form more nuanced rationales for why civic engagement is important and what actually constitutes this engagement, it makes sense to build a case for why or why not political participation is important. If society values political participation, it then stands to reason that voting and other forms of that participation are important and should be discussed in as many courses as possible in order to produce citizens who understand the intrinsic and extrinsic benefits. It could even be suggested that the extrinsic benefits are the most important as one begins to give up their individualistic views and approach a more collectivist society.

Bridging the divide between multiple disciplines, will be necessary to produce a truly interdisciplinary approach to citizen development; however, political science can and should be at the forefront of this approach. There are important reasons to take an interdisciplinary approach to explain a specific phenomenon that a particular field may not be able to completely explain. As Metzger and Smetana (2010) note, "political scientists have focused on how individuals acquire beliefs and attitudes from social contexts including schools or intergenerationally from parents" (226). However, according to, "constructivist theories of development, individuals actively create their own meaning systems through dynamic interactions with the environment" (226). These two explanations are complimentary, combining as they do structural and individual (behavioral) explanations. Using an interdisciplinary approach to educate citizens about democracy, may provide the most effective means to ensure that knowledge is actually internalized; thus, resulting in citizens who want to participate in democracy. 
Individuals entering college between the ages of 18 and 25 are entering a period of life that psychologists identify as "emerging adulthood." It is during that time that those individuals really start to explore their own identity and make choices that will impact their lives. With this comes the development of a person's citizenship and how engaged they will be in their own society. It should not be surprising that universities have become a place where civic engagement and democratic participation has developed because understanding the role that higher education should play in the development of American citizens has been discussed for the better part of the last half-century. From politicians to scholars, a debate has raged about what part, if any, higher education institutions should have in helping to ensure a civically engaged people. Research has focused on the idea of what constitutes civic engagement and what role universities need to play in obtaining this idea of being civically engaged (Saltmarsh and Hartley 2011).

Recalling the work of Gallatin and Adelson (1970), Metzger and Smetana conclude "adolescents balanced notions of the responsibility to the public good with beliefs about individual freedoms and choice" (232). This finding, in addition to Helwig's $(1995,1997)$ research on adolescent reasoning with social and moral concerns, seems to suggest that adolescents are at the prime age to be fully delving into ideas of social responsibility and the role of the citizen. In addition to this, Metzger and Smetana (2010) conclude, "with age, children develop theories about the social order through interacting with and interpreting the prevailing ethos and values of their society. Adolescents develop beliefs about the types of rights and benefits" (232). This research builds on the idea of providing civic education for students in primary and secondary school. Employing civic education in a student's formative years is not necessarily disputed, but why wouldn't a student's civic education then continue into their undergraduate education? Is there a way to make sure that citizens are being produced who may 
not necessarily understand all of the intricacies of the democratic institutions but do understand what their role in democracy is expected to be? Yes, but why are institutions of higher education the place to continue, or potentially start, this type of civic education; more specifically, how can institutions of higher education play a role in the development of the country's citizens?

\section{Why Institutions of Higher Education?}

Schuetze (2012) notes that universities tend to have 3 missions: teaching, research, and community engagement. However, as institutions continue to compete for a declining number of applicants, the focus of higher education turns toward fiscal matters. As Zinshteyn's (2016) piece in The Atlantic and Newfield's (2016) book contend, privatization has impacted how universities focus on the mission. Instead of focusing on student success, institutions find themselves in a battle to obtain more funding in order to lure more students to their campus. Therefore, if an action does not have an apparent monetary value, it is quite possible that it is not the focus of the institution. Richard Freeland (2018), from The Chronicle of Higher Education, contends in a piece for the online magazine that George Keller's 1983 book, Academic Strategy, saw the focus on the university shift into a more "professional approach to campus leadership." Freeland goes on to document that higher education has been dealt a serious of financial setbacks, often as a result of budget cuts from state governments, that has often found them focusing on the bottom line. If something does not produce an economic benefit to the institution, or if the financial benefit is not evident, often times that program does not make it through budget cuts. While universities strive to maintain low student to faculty ratios, while producing high levels of research, there is considerably less appeal to focus on community engagement. Schuetze (2012) believes that because the process of community engagement is not refined or the benefits welldocumented, it is hard to motivate universities to contribute to the third mission. If the results are 
not quantifiable and universally applied, it is difficult to persuade an institution to promote that specific mission. As universities across the country are forced to find new and innovative ways to fund academic ventures, the social capital facet of community engagement may not be as enticing because of the limited financial reward that comes with developing citizens. If institutions of higher education fail to see the benefit in educating citizens for participation in democracy, it is difficult to see how this endeavor can be successful. However, there can be little doubt that these institutions provide some of the most fertile ground for helping to develop citizens.

Even though economic factors may limit a university's willingness to focus on the development of citizens, scholars have documented that universities are constantly asked to somehow enrich the communities in which they exist (Lerner and Simon 1998; Kenny et al., 2002). The idea of community enrichment builds on the land-grant mission of universities and its "service to society" (Bonnen 1998, 27). Bonnen goes on to note that the land grant idea "is a set of beliefs about the social role of the university" (28). On a broader note, he suggests that universities have "historically... served society in every epoch by training and professionalizing" those who attend their institutions (31). While those who have been granted admittance to higher education institutions has changed over the course of the nation's history, it has always been a primary focus to train those in attendance to be members of society who are able to contribute to society. Based upon this rationale, it is not difficult to imagine how making sure an institution's students are engaged citizens naturally become a part of the narrative. Bonnen goes on to suggest that higher education, land-grant, state, and private research focused institutions are "now increasingly alike in their functions and societal roles" (46). This means that these institutions, once more specialized in their approaches (i.e. teaching schools), are not offering a wide variety 
of courses and services to students that often make them indistinguishable from one another. Therefore, it seems appropriate to argue that most higher education institutions should be developing the nation's citizenry and that one type of institution does not place more or less stock in the importance of this occurring; however, to what degree that this is occurring remains up for debate.

A Crucible Moment: College Learning \& Democracy's Future (2012) contends higher education institutions need to "focus... on the role that education should play in helping all students prepare for their roles as citizens" (various 29). This is an important challenge for universities; because it really questions what role the university will take in helping to create better citizens, citizens that are able to function and perform roles and actions within their democracy. A Crucible Moment also provides an important foundation for understanding what universities should be doing. There are five essential actions that are outlined for universities and general society in order to help ensure that future generations do not continue to lose social capital, as Putnam claims. Those actions are: (1) championing civic learning; (2) strategically refocusing existing programs; (3) creating financial incentives for students to participate; (4) increase funding for educational reform and research; (5) regularly report on progress of these goals and changes that can be implemented $(2012 ; 41-43)$. The focus of this research will address issues 1,2 , and 5 . It is the hope that by addressing these areas, solutions will begin to emerge for areas 3 and 4 .

To that end, A Crucible Moment also provides an understanding that there are more stakeholders involved in a student's ability to increase their social capital. The issue of incorporating the institution, faculty, student, and community together in order for the student to see the tangible results of their service is not ground-breaking. In fact, this is established by 
Bringle and Clayton's (2012) idea that reciprocity helps to build a strong social commitment of the student. Therefore, it is not surprising that this "National Call to Action" would focus on different actors who are essential in helping to ensure that students are offered the ability to become better citizens while they receive an education.

Without institutions of higher education playing an important role in the education and development of citizens, it is difficult to imagine how it is possible for the development of social capital to occur. While high schools have often served as an incubator for democratic education, there is some evidence to suggest that civics courses structured as they currently are may not adequately prepare students for participation in democracy (Kahne, Chi and Middaugh, 2006). Therefore, it would seem intuitive for democratic education to continue, or perhaps even start, in institutions of higher education. According to the U.S. Department of Labor's Bureau of Labor Statistics, "66.7 percent of 2017 high school graduates age 16 to 24 were enrolled in colleges or universities." This number signifies that higher education institutions have the opportunity to ensure that a majority of high school graduates are able to receive at least some level of information regarding their role in American democracy.

It is important to note that not everyone has the ability or desire to attend an institution of higher education. Therefore, it would be dangerous for the country to completely focus on efforts to increase political participation merely in a higher education setting. However, there needs to be action taken at some level to help build a robust citizen. Merely suggesting that colleges and universities be a catch all of that development would miss a significant segment of the population. Still, these institutions should be viewed as a good starting place for development to occur. In the future, these institutions may be able to partner with primary and secondary schools in order to further bolster the education of younger citizens. 
Higher education institutions are at an interesting crossroads. Do they continue to offer opportunities that help to bolster civic engagement (i.e. experiential education) or do they focus on endeavors that produce a greater upfront and immediate return for their investment? While the answer would probably be that immediate return, if you believe Putnam's argument about declining social capital, these institutions provide the best place to nurture social capital. This means it is vitally important for these institutions to focus on long term goals instead of shortterm gains. As the research indicated, identity exploration is occurring during this life phase, and a failure of the university to capitalize on the ability to educate students in order to become better citizens would be a detriment to the service mission of universities. Therefore, it is necessary that research be conducted so that curriculum can be updated in order to maintain the strong role that universities have played in helping to create generations of citizens who are educated and have expanded their social capital, making them vital components in America democracy. Without this continued support, it is possible that social capital will continue to diminish.

\section{Maintaining the Republic and Political Associations}

The conversation around a political science and the use of higher education institutions as impetus for building civic engagement would not be complete without understanding how these ideals and mores lead to a citizenry who participates in democracy. As de Tocqueville suggests, the democratic institutions of American only continue to exist because of "circumstances, laws, and mores" (353). He contends that laws and mores provide America with the success of democratic institutions more than just happenstance would allow naturally. Perhaps it is important to note that de Tocqueville reasons that democratic institutions in the U.S. are different than their counterparts. 
Even more interestingly, de Tocqueville discusses how associations in the U.S. present a unique opportunity for American democracy to flourish, where other states would not necessarily be as fortunate. "In the United States, people associate for purposes pertaining to public security, commerce and industry, morality and religion" (215). These associations then naturally lead to political associations, which he mentions can be freely obtained by citizenry. He even goes further to suggest than man may give up some individual rights in the hopes of collectively acting. This would suggest that understanding individual rights and the collective will are important components for citizens to be able to define and differentiate.

It can be reasoned that de Tocqueville's observations about America present a good case study in order to understand what makes American democracy different than democracy in other parts of the world. What is commonplace here, or even works here, may not be so relevant in other democracies. Furthermore, his analysis suggests that Americans need to understand their own rights, in order to know when the collective rights outweigh individual rights. This debate would seem to suggest that the political science education provides a good groundwork for citizens to know what their own rights are and how to employ those rights to achieve a means.

The debate on individual and collective rights naturally allows for the discussion of civic engagement to come up. Why do individuals have any need to participate in democracy, especially if they only care about their own rights? It stands to reason that citizens would want to participate in a democracy that may more severely curtail or even expand their rights. By failing to engage in one's own democracy, they leave important choices up to others who do participate. If Americans value individual liberties, it follows that they would want to participate in any way possible in the choices that governs those liberties. Ultimately, the question needs to be asked: why should Americans, especially those who are high school and college aged, be asked to 
participate in democracy? The answer is clear: their own individual rights. Failure to be civically engaged can threaten one's own rights.

All of this begs the question, what is the goal of the American experiment? Morone (1998) finds that there is a divide over a classical liberal versus classical republican interpretation of that experiment. Under the liberal interpretation, "Americans designed their regime to protect private rights from public meddling" (15). In other words, Americans were focused on the idea of self and preserving and promoting their own sense of self. Conversely, republicanism contends that America was founded under the pretense of a "subordination of individual interests to the res publica" (16). Morone suggests that both viewpoints ebb and flow over the course of American democracy, but it is the debate over "individualism and broad communitarianism" that ultimately frames the question of what the motivating goal of American democracy is (18).

Morone argues that "classical republicanism" is still evident in today's America; though its focus may be somewhat different than during the founding of the nation (73). However, "the call to community and collectivism remains...always elusive, always beckoning" (73). This suggests that there is a push and pull occurring within the debate over the goal of our democracy. Should government exist to protect the individual or promote a sense of community? Is it possible for both to be the goal?

\section{What is Civic Engagement?}

Understanding how citizens participate in their own governance is necessary in order to discuss civic engagement but is first necessary to define civic engagement before one can understand the historical and current implications of its implementation on college campuses. While there are various definitions for this term, one seems most applicable. This definition encapsulates both political knowledge and action. It comes from McCartney (2013), as she 
writes for the American Political Science Association's State of the Profession Series. She concludes:

"civic engagement is a catch-all term that refers to an individual's activities, alone or as part of a group, that focus on developing knowledge about the community and its political system, identifying or seeking solutions to community problems, pursuing goals to benefit the community, and participating in constructive deliberation among community members about the community's political system and community issues, problems, or solutions. It means actively participating in and seeking to influence the life of the community, whether motivations emanate from self-interested reasons, moral principles, altruistic concerns, political view- points, or any combination thereof" (14).

By looking at this definition it is clear that there are a lot of moving parts in the definition that need to be addressed. However, this definition clearly identifies that the primary focus on civic engagement is a person's role in their community, whether it be local or national. Still, what remains more confounding is whether higher education is the place to achieve the goals of creating students who are engaged with their communities.

McCartney's definition ties back into the ideas promoted by de Tocqueville. How citizens are evaluated on their own participation in democracy relates to their own idea of individual rights and the rights of the general will. While it may be difficult, understanding how citizens decide what is important to them clearly drives their desire to participate in democracy. The motives that McCartney suggests, highlight that an individual must decide why they should or should not participate. Institutions of higher education present an opportunity for students to be presented with information that allows them to make those decisions and to decide their own motivations.

\section{Social Capital: Definition and Application}

What is social capital? Answering that question is not as simple as those studying the matter would presumably like it to be. In fact, there are various definitions surrounding social capital, but it is probably most important to start with the social scientist that most reference as 
the standard bearer for the theory, Robert Putnam. "'Social capital' refers to features of social organization such as networks, norms, and social trust that facilitate coordination and cooperation for mutual benefit" (Putnam 2000, 67). These components can be simplified to just networks, norms, and trust (Farr 2004). Putnam argues that social capital is on the decline, and as a result American democracy is in trouble (1995a, 1995b, 1995c, 2000). Is there more to social capital than is being conveyed by Putnam? If there are, it is necessary to highlight these differences in order to have a thorough understanding of what will be measured in subsequent chapters.

First, it is necessary to examine what is meant by the term "networks", since it is within these networks that norms and trust are developed and formed. In the current society, social networks can often be thought of as Facebook, Twitter, or some other form of social media community. However, that is not necessarily the networks that scholars of social capital are examining, at least in the mid 1990s through mid 2000s. The types of social networks scholars like Farr and Putnam reference normally have some kind of obviously political motivation to them (La Due Lake and Huckfeldt 1998). They measure social capital in "terms of communication about politics within an individual's recurrent network of social relations" (571). This focus stresses the roles of political ideas and conversations in the maintenance of social capital and democracy. Still, this is not always the case, especially when looking at other forms of voluntary networks with social interactions that form the bonds of a network (Putnam 1995a; 1995b; 1995c; 2000). While Putnam does note the relation to solving economic or political problems within these organizations, his use of bowling leagues is intrinsically apolitical. That is, it would be difficult to find an individual who joined a bowling league for the rousing political rapport that they would have with their fellow bowlers - rather they join for social connections. 
While political discourse may result during game play, it is not the motivating factor behind the league, or the reason people sign up for the league. Still, such social connections do create a common bond that may underscore notions of community, obligations towards others, and classical republican values that Morone suggest in his work.

Still, this preoccupation with what constitutes social networks may be misdirected (McClurg 2003). Within his work, McClurg finds that "not all forms of societal interaction are important" (460). His research supports the idea that sometimes political action does need to be accounted for, and that all social networks are not necessarily created equally. That is not to say that other interactions do not count as social interactions, but it is necessary to account for as many different variables when trying to ascertain participation levels of individuals. Failure to adequately address these variables will lead to either under or over reporting of an individual's social connectivity. This would have negative consequences for those trying to gauge whether participation is on the decline, as Putnam (2000) suggests. Perhaps it is the changing nature of associations that would lead one to surmise that social capital is on the decline.

It is important to note that Putnam's conceptualization of social capital is not without fault or challenge from other academic scholars. In fact, Portes (1998) contends that the measures discussed by Putnam lack clear definition, fail to address causal relationships, and control for spuriousness. Putnam's (2000) response in Bowling Alone did little to stop the ire of sociologists who still questioned how he developed his Social Capital Index (SCI) (Portes and Vickstrom 2011). They go on to note that the social capital that Putnam's notes is nothing like social capital as originally envisioned by sociologists Pierre Bourdieu and James S. Coleman (462). This is particularly interesting, as many political scientists cite Coleman as one of the original developers of the modern term. 
Portes and Vickstorm contend sociologists defined social capital as "the ability...to command resources through their membership in networks and other social structures"; whereas, Putnam viewed it as a public good (462). Needless to say, Portes and Vickstrom were not supportive of Putnam's terminology. Their own research suggests that Putnam's theory of social capital fails to address underlying problems with diversity and immigration, and that Putnam's promotion of diminishing social capital is misplaced (475). Putnam's failure to adequately address concerns about immigration and ethnic diversity in relation to declining social capital is a major point of contention. While this may seem nuanced, the best critique of Putnam's social capital measure, is the idea that perhaps "communitarianism and interpersonal trust" may not be the best way to "produce social cohesion" (476). Once you control for a variety of factors, (i.e. inequality, level of education, racial composition) that Putnam does not, the "alleged benefits of social capital largely disappear" (476). They base this assertion on the sociological perspective that division of labor and strength of institutions is primarily responsible for social cohesion. This perspective suggests that social capital may not be properly measured, at least in the terms of the sociological framework.

Sociologists are not the only ones finding gaps with Putnam's notion of social capital. Farr (2004) notes that Putnam did not originally address the idea of education in regard to social capital, but now hails it as necessary if creating civically engaged individuals is desired (28). Farr also notes that increasing social capital through education is not an easy task, and therefore educators should be prepared for a challenge when trying to engrain it through pedagogy and curriculum. He goes as far to note that Putnam's ideas may be well intentioned, but civic educators like Dunn, Dewey, and Hanifan need to be taken into consideration to get the full effect of developing social capital (28). 
A thought-provoking piece in The Atlantic by Nicolas Lemann (1996) questions most of what Putnam contends, at least throughout the early and mid-1990s. Lemann believes that Putnam's theory was too quickly adopted and that he failed to address some underlying problems when he discussed the decline of American social capital. Lemann believes that Putnam is too passé when he argues that bowling leagues are any more indicative of social interaction than youth soccer leagues. Although not generally cited for its scholarly merit, Lemann's article provides valuable context for social scientists who are trying to ascertain whether or not Putnam is actually measuring the decline in social capital. It would seem that Lemann, Portes, and Vickstrom would all be in agreement that Putnam is showing something in his work, but everything is not necessarily as Putnam presents it, and that could pose a problem for any researcher using his methods.

Hanifan's $(1912,1914,1916)$ work centered around poor, predominately African American West Virginia schools and the idea that to "become good citizens" they would need a "helping hand" to develop the skills required to be productive citizens in the country $(53 ; 29,32$; 88). However, according to Farr, this rationale, used incorrectly by Putnam, is to blame for the work of Smith and Kulynych (2002). Smith and Kulynych go into great detail about why or why not to call social capital, something like "social resources," but Farr (2004) maintains that it fails encapsulate Hanifan's ideal of "education... at the center of public life" (12), the idea schools could equip citizens to be more engaged in the events that shaped their lives. It may be that Smith and Kulynch's refusal to define social capital as social resources is incorrect. It is even conceivable that using another terminology would satisfy sociologists and early $20^{\text {th }}$ century civic leaders that Farr notes.

So, if there are potential problems with how Putnam defines and measures social capital, 
why use his measure at all? As McKinlay (2013) notes, it "provided a different conception of civic engagement from strict partisan political activism" (237). That is, Putnam's view of social capital allows for participation in democracy to not be completely based on partisan participation, but on various other measures that often lead to a more engaged citizen. Putnam's work helps to bolster the idea that social capital is not merely obtained or collected in order to gain partisan advantage, but social capital is the desire of citizens to participate in the "creation and animation of the public realm" (237). For the purpose of this dissertation, I think of social capital as "connections among individuals—social networks and the norms of reciprocity and trustworthiness that arise from them" (19). This means "social capital" involves political participation, civic participation, religious participation, trust, and informal (social) connections. These terms build on Putnam's (2000) work, with elements of Engbers et al. (2017).

\section{Combining Experiential Education and Citizenship}

Before one can understand how citizenship can be linked to experiential education, it is first necessary to discuss what experiential education actually is. Much like social capital, there is some debate about how to define experiential education. Kolb and Kolb (2005) suggest that the works of John Dewey, Kurt Lewin, Jean Piaget, William James, Carl Jung, Paulo Freire, Carl Rogers help to "develop a holistic model of the experiential learning process and a multilinear model of adult development" (194). Experiential learning theory (ELT) builds on six common threads:

1. Learning is best conceived as a process, not in terms of outcomes. To improve learning in higher education, the primary focus should be on engaging students in a process that best enhances their learning. [...]

2. All learning is relearning. Learning is best facilitated by a process that draws out the students' beliefs and ideas about a topic so that they can be examined, tested, and integrated with new more refined ideas. 
3. Learning requires the resolution of conflicts between dialectically opposed modes of adaption to the world. Conflict, differences, and disagreement are what drive the learning process. In the process of learning one is called upon to move back and forth between opposing modes of reflection and action and feeling and thinking.

4. Learning is a holistic process of adaptation to the world. Not just the result of cognition, learning involves the integrated functioning of the total person - thinking, feeling, perceiving, and behaving.

5. Learning results from synergetic transactions between the person and the environment. In Piaget's terms, learning occurs through equilibration of the dialectic processes of assimilating new experiences into existing concepts and accommodating existing concepts to new experience.

6. Learning is the process of creating knowledge. ELT proposes a constructivist theory of learning whereby social knowledge is created and recreated in the personal knowledge of the learner. (Kolb and Kolb 2005; 194)

These six themes of ELT suggest the experiential education is about constantly asking everyone involved to reassess and question what they think they know. Both the educator and the student should be trying to understand varying points of views by undergoing new experiences. If this occurs, the learner is actually able to learn about a situation, rather than trying to understand how a particular theory may or may not be playing a role in a situation. If the learner is able to actual experience something, theories or concepts discussed in the classroom may be able to have realworld application. This is particularly important for student development and learning in academic courses (Kuh 2008; Austin and Rust 2015).

Probably one of the most interesting definitions for experiential education comes from the Association for Experiential Education. Their webpage suggests that "Experiential education is a philosophy that informs many methodologies in which educators purposefully engage with learners in direct experience and focused reflection in order to increase knowledge, develop skills, clarify values, and develop people's capacity to contribute to their communities" ("What is Experiential Education?"). This definition compliments both de Tocqueville's understanding of American associations and Putnam's ideas on social capital. While the learning that may be 
occurring may not necessarily be politically focused, experiential education really focuses on developing a person so that they can provide some meaningful contribution to their community. In other words, experiential education helps learners become better citizens, even if the learners do not realize that is occurring and even if that is not the intended goal.

Throughout the subsequent chapters, experiential education will be evaluated to show effectiveness in generating social capital and empathy in students. It will provide a framework for the ability of political science educators to integrative new teaching pedagogy into the classroom with the desire to build social capital. Chapter four will examine the use of servicelearning and professional field experience in the classroom in order to determine if social capital changes from the beginning to the end of the semester. Chapter five evaluates if students who participated in service-learning and professional field experience classes continue to develop social capital once removed from the context of the course and experience. Chapter six examines how (if) the inclusion of virtual reality into the classroom enables students to develop empathy, thus increasing their ability to connect with individuals who are not within their social group (bridging versus bonding social capital).

The three empirical chapters thus seek to identify if experiential education provides a way of increasing social capital and empathy in students in political science and other academic settings. They also address whether there is some link between experiential education and the ability of students to develop social capital, both in an academic setting and once they leave the confines of a university. Finally, they seek to identify ways that political science educators, as well as educators in other disciplines, may use various teaching techniques to produce social capital. As such, it addresses three questions: 1) Does experiential education effect the development of social capital over the course of an academic semester? 2) Does participating in 
experiential education while in college eventually effect how much social capital a person has after the end of their university experience and are those individuals more likely to have more social capital throughout their life? 3) Does experiential education effect the development of different types of social capital and the development of empathy? 


\section{Chapter Three: Mission Impossible? - Can Service-Learning and Professional Field Experience be Effectively Implemented by Institutions of Higher Education to Create Social Capital in Students?}

This chapter focuses on the use of experiential education and how social capital can be developed over the course of an individual semester. Can social capital be increased by the use of experiential education? Are one or more types of experiential education better at developing social capital than others? Chapter 3 answers these questions, as well as identifies the type(s) of experiential education best suited for the development of social capital. Because the term experiential education is used liberally to describe different forms of teaching and learning, it is important to establish the value of particular forms of experiential education in creating better citizens and increasing social capital.

\section{A Crucible Moment? Can Institutions of Higher Education Fulfill Their Mission?}

A Crucible Moment: College Learning \& Democracy's Future (2012) contends higher education institutions need to "focus... on the role that education should play in helping all students prepare for their roles as citizens" (29). A majority of research conducted around experiential education in a higher education setting focuses on pedagogy and best practices. This research fails to address the underlying issue of whether or not experiential education is fulfilling part of a university's mission to create more civically engaged students.

In order to determine if/how experiential education creates citizens with higher social capital it is necessary to examine how two experiential education models, service-learning and professional field experience, effect the level of social capital. This chapter seeks to discover if students involved in civically engaged settings, as indicated by their enrollment in courses that stress politics, will have higher social capital scores than their peers not enrolled in politically oriented courses. At least initially, these students will have higher social capital scores than 
students enrolled in other liberal arts or STEM focused courses This will be identified on pre-test data. It is speculated that the form of experiential education is secondary to the inclusion of civic engagement in increasing social capital. Therefore, if colleges and universities are instituting experiential education programs with the purpose of creating more engaged citizens, curriculum revisions may be necessary.

Experiential education is not a recent addition to classroom learning. In fact, John Dewey's (1938) work on education provides some of the groundwork for what experiential education would become in the $20^{\text {th }}$ and $21^{\text {st }}$ centuries. His work helped usher in the idea that typical education was sometimes too rigid and focused on classroom but no real-world application. Experiential education enabled students to become better connected, not only to their schools, but to their communities and government. It is through this connection to the community that one would hope to foster a sense of civic participation. Since service-learning and professional field experience takes the student-centered learning from inside to outside the classroom, experiential education should enable students to engage with people in various communities. Because they are engaging with those people, the thought becomes that those students will experience more bonding to those in the community and the community as a whole. If students are more concerned about affairs in their communities, they would then be concerned with good governance of those communities and therefore would become more engaged civically and politically.

While Hunter and Brisbin (2000) did find that "service apparently has some value for increasing political knowledge and fostering civic responsibility," they warn against trying to use service as a catchall for creating those traits in students (626). This suggests that servicelearning may not be able to provide consistent results that could be replicated semester after 
semester. However, the same could also be reasoned for the use of professional field experience. Still, it is important to measure if these forms of experiential education do produce a desire in students to become more civically engaged. Hunter and Brisbin's work took place almost twenty years ago; consequently, it is possible that experiential education's implementation has been worked out to better address concerns that it is not universally applied in classroom settings.

This research is important because it looks at the bonds students are forming with their communities and government. Since institutions of higher education are using experiential education anyway, it is important to see if there are civic dimensions to the otherwise well documented benefits of experiential education. As Wilson (1997) contends "schools and universities that educate their students with the values and skills to build social capital" are helping to create better communities and citizens (757). This research is especially important if institutions want to point to experiential education as a means to build social capital.

As was addressed in chapter two, there are many well documented studies that support the use of service-learning to increase a student's connection to a community. Therefore, the following research seeks to ascertain whether or not social capital can be bolstered. If the research is already there that suggests students feel more community connection, it reasons that students may then participate more in that community. This alone would cause students to develop social capital. The questions then become, will service-learning make a student more likely to trust those in both in and out groups, participate both politically and religiously, and develop meaningful social connections?

The following sections highlight why these methods of education are important to the development of citizens and how they can be used in both political science, and non-political science classes. It is important to connect "theory to application" because it "helps students more 
fully understand the duties and capabilities of citizens in a democracy and provides a starting point to build social capital" (Rios Milllet McCartney and Chaban 2013, 271).

\section{What is Service-Learning:}

One form of experiential education that is evaluated in the empirical portion of this chapter is service-learning. While his definition is now over 20 years old, Furco's (1995) detail of service-learning is still widely employed and the basis for a vast majority of service-learning programs. His definition suggests that service-learning is "distinguished from other approaches to experiential education by [its] intention to equally benefit the provider and recipient of the service" (5). Pared-down to its core, this means equal parts services and learning. He notes that service-learning is different from other forms of experiential education because it seeks a balance to learning and service. Students who are exposed to this type of learning would be able to serve, while also integrating concepts and theories into their service. An example of this type of experiential education would be a political science student serving at a non-profit that focuses on producing environmentally friendly office supplies. The student would be able to integrate knowledge of public policy theory as he or she helps advise the non-profit.

Research has identified important contributions that service within a classroom setting adds to a students' educational achievement (Astin and Sax, 1998; Astin et al., 2000; Vogelgesang and Astin, 2000). Still, there is research to suggest that service is often misused or misunderstood (Reinders \& Youniss 2006). If this is the case, it is not difficult to comprehend that service-learning would not yield the expect results that one would hope for. That is, research examining service-learning that is not properly vetted would yield results that do not completely encompass what is occurring. This is especially concerning if one is looking to show the tangible 
benefits of service-learning. Therefore, it is necessary to have a clear goal (and definition) in mind when conducting service-learning research.

Service-learning exposes students to the community, asks them to integrate their fields of study into a specific project, and critically deduce important skills sets that can be tied into learning objectives in a classroom setting. This is supported by Bringle and Hatcher's (1996) use of service-learning as a way to ensure that students are becoming civically engaged. Bringle and Clayton (2012) build off their previous work and contend "reciprocal partnerships lend themselves readily to civic learning" (116). They also note that service-learning is a "critical component" necessary to foster civic engagement (118). This is paramount if actively trying to engage students with the end results being more civically engaged students. The idea of reciprocal relationships builds on the idea that Furco suggests of equal parts service and learning, and the rationale provided by Bringle, Hatcher, and Clayton support the idea that civic learning is possible if these reciprocal relationships are formed with community partners. Ideally, servicelearning is one of the best forms of experiential education in that regard because of the equal balance. This ensures a vested interest from the students and community partner. This interest is not necessarily evident in other forms of experiential education.

More and more research is being conducted which supports a linkage between service and some form of political efficacy, and potential development of social capital. "Volunteer activity builds social capital, and smooths the way for collaborative effects, including efforts directed at effecting political change" (Campbell 2000, 642). Campbell also notes that even though social capital may be stagnant or declining, that does not mean that America should not continue to invest in increasing social capital. The ability to invest in the development of social capital eventually falls back onto the desires of society. If society is not in support of these 
initiatives, it is difficult to see how service can be supported, at least on a national level. As universities and colleges around the country continue to see budget cuts, it is not completely outside the realm of possibility that the university's "third mission" could be eliminated in favor of the other two missions which offer monetary benefits. Still, the information provided in this chapter should help to persuade skeptics that a university has a role in helping to maintain and create citizens who are willing to participate and be engaged in their democracy.

In 1998, Campus Compact reported that $99 \%$ of surveyed institutions reported using service-learning in at least one class (Building the Service Learning Pyramid). This is not surprising considering the aforementioned research that supports positive benefits for students, not just in civic responsibility, but student well-being as well. If almost every university in the country is currently using some form of service-learning, based upon over 200 definitions, there has to be something that is working when looking at what service-learning actually offers. Kenny and Gallagher (2002) argue that service-learning "builds on the traditions of volunteerism, service and social activism in American culture" (19). This is not something that is completely unexpected, but it bolsters the argument that service-learning's ability to increase social capital exists. Also, with so many universities nation-wide supporting this type of experiential education, there has to be some benefit for exercising this educational model.

The strongest support for service-learning's ability to increase social capital comes from Morgan and Streb (2001). Their research concludes that "when students have real responsibilities, challenging tasks, helped to plan the project, and made important decisions, involvement in service-learning projects had significant and substantive impacts on students' increases in self-concept, political engagement, and attitude toward out-groups" (166). The impact that service-learning can have on students is not in doubt, but Morgan and Streb did note 
that many conditions must be meant.

Service-learning is not experiential education that merely addresses the needs of classroom educators. In fact, some research has shown that "service-learning grounded in traditional classroom instruction and assignments can lead to political engagement" (Lorenzini 2013, 135). Lorenzini concludes that political scientists must help draw the link between servicelearning and political engagement. By helping students to understand their ability to affect change in their communities, it is possible to see how an idea of social capital rooted in the betterment of communities would be able to develop and increase.

\section{What is Professional Field Experience:}

Another type of experiential education that will be evaluated throughout this chapter is professional field experience. Whereas, service-learning hinges on a balanced approach to service and learning, professional field experience asks the learner to complete tasks that enable them to incorporate theories and concepts into real world settings, but without the focus on service. The type of professional field experience used in this research will be a student's participation in Model United Nations (UN). This means that students participate in a simulation of the UN. Students are asked to conduct research, produce foreign policy position papers, and finally collaborate on resolutions that imitate actual resolutions produced by the United Nations in New York.

Research suggests that Model UN enables students to connect "theories and data taught in class" to real world situations (McIntosh 2001, 276). As mentioned, this form of experiential education focuses more on the learning than on actual service. Furthermore, Model UN asks students to participation in a simulation that is more interdisciplinary in nature since they must integrate ideas from the classroom into real world situations. Phillips and Muldoon (1996) 
suggest that participation in Model UN increases a student's ability to "develop knowledge and skills that are essential in the global business environment." This suggests that there is applicability to this form of education across multiple disciplines. While the actions of the simulation will not produce real legislative accomplishments, these simulations provide a unique opportunity for students to take classroom material and directly integrate it into real-life experiences.

\section{Experiential Education Theory and Social Capital}

While Hunter and Brisbin (2000) evaluated service learning and the impact on civic engagement, their research failed to note any concrete examples of students becoming more engaged in their governance. There were some benefits to the use of experiential education, specifically service learning, but there were no measurable results that seemed to implicate experiential education as a reliable means to increase civic engagement. This is concerning for

educators who seek ways to make students more engaged, especially through political participation. Also, as Hunter and Brisbin note, it is often difficult to account for how the instructor uses the form of experiential education, and this can cause students to not understand the implications of their experience. It is possible to go a step further and say that it is even more difficult to control an experience that takes places outside the bounds of a classroom.

The following hypotheses focus on the use of experiential education to develop social capital over the course an academic semester. The question suggested at the beginning of this chapter seek to identify means to increase a student's social capital while enrolled in undergraduate coursework. Understanding this is necessary if educators hope to gain an understanding of how the attitudes of students can be shaped, especially in relation to their roles in democracy. Research, like that conducted by Hunter and Brisbin, suggests that some types of 
experiential education can have an impact on qualitative responses of students (Smith 2006).

This means that students have a positive impression of using experiential education in the classroom. However, the same is not necessarily true of quantitative results. This indicates that students do not display quantifiable changes in responses to items, such as social capital. Still, there are findings to suggest that experiential education does lead to a student's awareness of their own civic education and the ability to address that education (Harris 2010). Because of the competing narratives proposed by this research, one would anticipate an increase in social capital scores if experiential education plays a part in a student's civic development. In order to test assumptions on that development, the following hypothesis is suggested:

$\mathrm{H}_{1}$ : Students engaged in experiential education in a formal classroom setting will experience an increase in their social capital scores over the course of the semester.

Furthermore, Campbell (2000) argues, "[t]he thicker the networks of social connectedness among students and between students and adults within their community, the more opportunities a norm of generalized reciprocity will have to develop" (644). So, it is necessary to address whether it is possible to "thicken" the bonds between students, educators, and communities. That thicken will be evident in either bridging or bonding social capital development. It may be possible to see that development in the bridging and bonding variables, while not in the social capital index overall referenced in the previous hypothesis. Therefore, it is important to look at the type of social capital being developed. If thickening is occurring, it should be possible to see a change in the bridging and bonding social capital scores from the beginning to end of the semester. As such, the following hypothesis is proposed:

$\mathrm{H}_{2}$ : Experiential education will have a positive relationship on both bonding and bridging social capital scores. 


\section{Methods, Participants, and Study Design}

The sample recruited to participate in this survey was part of either a service-learning ${ }^{2}$ or professional field experience ${ }^{3}$ course during the spring of 2018. Respondents were asked to complete a survey at the beginning of the semester before starting any experiential education and at the end of the semester, once their experiential education was complete. There were 419 students enrolled in service-learning courses and 50 enrolled in the professional field experience course, for a total of 469 . The sample $(n=157)$ of respondents participating in the survey at the beginning of the semester shows a participation rate of $33.47 \%$. The sample $(n=101)$ of respondents in the survey at the end of the semester shows a participation rate of $21.54 \%$.

In each survey (beginning and end of semester), respondents were asked to indicate what course they were enrolled in by asking; "In which of the following classes are you currently enrolled? Select all that apply." Participants could select the following answers: "1. COMM 112: Small Group Communication; 2. LDR 201: Principles of Leadership; 3. MDS 489: Capstone; 4. POLS 491A: Prof Fld Expr: Model U.N."” Respondents indicating “1," "2,” or "3” were coded

${ }^{2}$ Students were enrolled in MDS 489, LDR 201, or COMM 102. A further description of each course is provided in subsequent footnotes.

${ }^{3}$ Students were enrolled in a Model United Nations course, POLS491A. A further description is provided in subsequent footnotes.

${ }^{4}$ The following are the courses were the survey was offered and this is a course description pulled from the university catalog.

MDS 489: The MDS capstone instructs students on the methods and advantages of a multidisciplinary education. The capstone includes a community-service service learning project.

LDR 201: This course serves as an introduction to leadership theory and practice. The course will examine various aspects of the literature on leadership; provide practice for developing leadership skills; and offer personal experiences for self-reflection.

COMM 102: Introduction to interpersonal communication with emphasis upon application of one to one communication in a variety of social contexts.

POLS491A: Prearranged experiential learning program, to be planned, supervised, and evaluated for credit by faculty and field supervisors. Involves temporary placement with public or private enterprise for professional competence development. 
as taking a service-learning course; participants responding " 4 " were coded as taking a professional field development course. Approximately $73 \%$ of respondents were enrolled in a service-learning course $(n=115)$, and $27 \%$ were enrolled in a professional field development course $(n=39)$ for the survey at the beginning of the semester. As indicated previously, participants were asked the same question in the subsequent survey at the end of the semester; though approximately $51 \%$ or respondents indicated enrollment in a service learning course $(\mathrm{n}=$ $51)$ and $49 \%$ indicated enrollment in a professional field development course $(n=49)$.

Participants in each iteration of the survey completed the following questions. 
Table 3.1 Sample Characteristics

\begin{tabular}{|c|c|c|}
\hline & Beginning of the Semester Survey & End of Semester Survey \\
\hline$\overline{\mathrm{N}}$ & 157 & 101 \\
\hline \multicolumn{3}{|l|}{ Gender } \\
\hline Male & $40.1 \%$ & $38.0 \%$ \\
\hline Female & $59.9 \%$ & $62.0 \%$ \\
\hline Age & Mean: 20.5 & Mean 20.75 \\
\hline \multicolumn{3}{|l|}{ Race } \\
\hline White & $97 \%$ & $99 \%$ \\
\hline Black or African-Americans & $2 \%$ & $1 \%$ \\
\hline American Indian or Alaska Native & $.05 \%$ & - \\
\hline Asian & $.05 \%$ & - \\
\hline $\begin{array}{l}\text { Native Hawaiian or other Pacific } \\
\text { Islander }\end{array}$ & - & - \\
\hline \multicolumn{3}{|l|}{ Hispanic } \\
\hline No & $98.9 \%$ & $100 \%$ \\
\hline Yes & $1.1 \%$ & - \\
\hline \multicolumn{3}{|l|}{ State of Residence } \\
\hline West Virginia & $60 \%$ & $65 \%$ \\
\hline Other States/Territories & $35 \%$ & $33 \%$ \\
\hline International & $5 \%$ & $2 \%$ \\
\hline \multicolumn{3}{|l|}{ Social Class } \\
\hline Lower Class & $15 \%$ & $15 \%$ \\
\hline Working Class & $24 \%$ & $25 \%$ \\
\hline Lower Middle Class & $35 \%$ & $35 \%$ \\
\hline Upper Middle Class & $20 \%$ & $17 \%$ \\
\hline Upper Class & $6 \%$ & $8 \%$ \\
\hline \multicolumn{3}{|l|}{ Credit Hours } \\
\hline $0-28$ hours & $6 \%$ & $10 \%$ \\
\hline $29-58$ hours & $15 \%$ & $13 \%$ \\
\hline 59-88 hours & $35 \%$ & $30 \%$ \\
\hline $89+$ hours & $44 \%$ & $47 \%$ \\
\hline \multicolumn{3}{|l|}{ GPA } \\
\hline 1.9 and below & $9 \%$ & $3 \%$ \\
\hline $2.0-2.49$ & $18 \%$ & $20 \%$ \\
\hline $2.5-2.99$ & $25 \%$ & $27 \%$ \\
\hline $3.0-3.49$ & $30 \%$ & $31 \%$ \\
\hline $3.5-4.0$ & $18 \%$ & $19 \%$ \\
\hline \multicolumn{3}{|l|}{ Major } \\
\hline Multidisciplinary Studies & $55 \%$ & $35 \%$ \\
\hline $\begin{array}{l}\text { Political Science/International } \\
\text { Studies }\end{array}$ & $35 \%$ & $60 \%$ \\
\hline Other & $20 \%$ & $5 \%$ \\
\hline \multicolumn{3}{|l|}{ Previous Experiential Education (YES) } \\
\hline Community Service & $73 \%$ & $65 \%$ \\
\hline Service-Learning & $20 \%$ & $22 \%$ \\
\hline Professional Field Experience & $11 \%$ & $9 \%$ \\
\hline Internship & $22 \%$ & $15 \%$ \\
\hline
\end{tabular}




\section{Control Variables}

Gender - Respondents were asked to indicate gender and could select "Male" (coded 1), "Female" (2), or "Decline to state" (3). These were then recoded into a dummy variable for gender with "Male" remaining "1", "Females" being recoded into "0" and "Decline to state" being recoded as "Missing" or "99."

Age - Respondents were asked to indicate their age. They could answer with a preselected range from "18" (coded 1) to "26 or greater" (9). There were no responses over 26. Therefore, ages were recoded to scale measurement from 18 to 25 .

Race - Respondents were asked to select the race they considered themselves to be. Options were "White” (coded 1); "Black or African-American" (2); "American Indian or Alaska Native" (3); "Asian" (4); or "Native Hawaiian or other Pacific Islander" (5). These were recoded with "White" as "0"; "Black" as "1"; "American Indian or Alaska Native" as "2"; "Asian" as “3”; and "Native Hawaiian or Pacific Islander" as "4”. Respondents were also asked "Are you Spanish, Hispanic, or Latino?" Initially this was coded "1" for "Yes" and "2" for no; however, a dummy variable was created with "Yes" remaining "1" and "No" as "0".

State of Residence - Respondents were asked to indicated which state they resided in “when not attending college." Respondents could indicate any of the 50 states, the District of Columbia, or that they "do not reside in the United States." This variable was recoded with all respondents answering "West Virginia" as " 1 " and all "Other" responses " 0. ."

Social Class - Respondents answered "How would you describe your social class? Are you in the lower class, the working class, lower middle class, upper middle class, or the upper class?" Coded 1 through 5.

Credit Hours - Respondents answered "How many credit hours have you earned towards 
your bachelor's degree?" " $0-28$ hours" was coded "1"; “29-58 hours” (2); "59- 88 hours" (3); "89+ hours" (4).

GPA - Respondents were asked "What is your overall GPA?" Responses were coded “4.0 - 3.5" (1), "3.49-3.0" (2), "2.99-2.5” (3), "2.49-2.0" (4), and "1.9 and below" (5). However, these were recoded in reverse order to " 4.0 - 3.5" (5), "3.49 - 3.0" (4), "2.99-2.5" (3), "2.49-2.0" (2), and "1.9 and below" (1).

Academic Major - Participant was asked to indicated major program; however, with over 125 applicable majors, it was necessary to recode this variable into the categories with the most frequency. Therefore, responses were recoded into "Multidisciplinary Studies" (1), "Political Science/International Studies" (2), and "Other" (3).

Previous Experiential Education - Respondents were asked "Before this semester, have you ever taken a class that required you to do [experiential learning type] as part of your grade?" They were asked this for community service, service-learning, professional field experience, and internship. They could respond with "Yes" (coded 1), "No" (2), or "I don't remember" (3). These were recoded into "Yes" as " 1 ", "No" as "0" and "I don't remember" as "99" or missing.

\section{$\underline{\text { Social Capital Variables }}$}

A variety of surveys exist to measure social capital in the general population. However, each of these instruments seek to address a nuanced facet of social capital, whether that specific facet is specific form of social capital (i.e. bridging versus bonding) or a specific measure that makes up social capital (i.e. trust). As a result, the intention was for the survey used in this research to focus on the measures identified by Putnam (2000) in his work Bowling Alone, which include measures of: political participation, civic participation, religious participation, informal social connections, and trust. 
In 2000, the Social Capital Benchmark Survey was administered to "41 U.S. communities, to measure various manifestations of social capital.” In 2006 the Social Capital Community Survey (SCCS) was used to "assess change nation-wide and in the participating communities in dimensions of social capital" and was conducted for the Saguaro Seminar at the John F. Kennedy School of Government, Harvard University. The results of this survey were published in January 2009. The 2000 survey "builds upon two comprehensive efforts: the work of Professor Robert Putnam, Harvard University (author of Bowling Alone: Collapse and Revival of the American Community) and strategies for civic revitalization outlined in "Better Together"." It stands to reason that the follow-up survey in 2006 would be a natural extension of Putnam's work. Still, there are some limitations to this survey. While it was consulted as the questions were derived for the following research, the questions included are almost a direct wording from the American National Election Survey (ANES) from 2016. This should allow for additional comparability to a more generalized population in subsequent analysis.

As various institutions and scholars have suggested, social capital can be conceptualized and measured in a variety of ways. This chapter focuses on Putnam's (2000) work in which he equates social capital "to connections among individuals - social networks and the norms of reciprocity and trustworthiness that arise from them" (19). As a result, this chapter builds on Putnam's (2000) work, but also incorporate that of Engbers et al. (2017) who try and merge terminology together across several disciplines (i.e. economics, sociology, and political science). In order to effectively evaluate social capital, it is necessary to use the same survey in the subsequent empirical chapters (Chapters 4 and 5) in this research; however, each empirical chapter seeks to address different ways that social capital may or may not develop.

The survey used in this chapter (see appendix $A$ to view survey in its entirety) will be 
discussed in the following subsections. The primary focus of this survey was to obtain a student's social capital score and bridging and bonding social capital scores at the beginning and the end of the semester. How those variables were constructed, measured, and analyzed follow.

\section{Political Participation}

Political participation is measured using questions from the ANES 2016 and the 2000 and 2006 Social Capital Benchmark Survey. Putnam's definition is critical to conceptualizing the concept of political participation (2000). As such, activities undertaken by respondents that deal specifically with "political" issues are noted here. Actions taken by the respondent, such as engaging in discourse about a political topic, contacting an elected official, or voting are included in variable construction. The following questions were asked to create a political participation variable.

\section{Political Participation} During the past 4 years, have you called a radio or TV show about a political issue, or have you not done this in the past 4 years? ? $^{+}$

During the past 4 years, have you ever sent a message on Facebook or Twitter about a political issue, or have you not done this in the past 4 years? ${ }^{+}$

During the past 4 years, have you written a letter to a newspaper or magazine about a political issue, or have you not done this in the past 4 years? ${ }^{+}$

During the past 4 years, have you contacted or tried to contact a member of the U.S. Senate or U.S. House of Representatives, or have you not done this in the past 4 years? ${ }^{+}$

During the PAST 12 MONTHS, have you telephoned, written a letter to, or visited a government official to express your views on a public issue? ${ }^{+}$

During the past 4 years, have you signed a petition on the Internet about a political or social issue, or have you not done this in the past 4 years? ${ }^{+}$

During the past 4 years, have you signed a petition on paper about a political or social issue, or have you not done this in the past 4 years? ${ }^{+}$

Did you vote for a candidate for President in the 2016 general election? ${ }^{+}$

Did you vote in the most recent election held in the area where you live? ${ }^{+}$

Note. + indicates question from ANES 2016; * indicates question from 2000 and 2006 Social Capital Benchmark Survey

For each of the political participation questions, respondents could answer "Yes" (coded

1), "No" (coded 2) or "I don't know" (coded 3). These were then recoded into dummy variables with "Yes" remaining "1," "No" now coded as "0," and "I don’t know recoded as "99" or missing. 


\section{Civic Participation}

Again, taking Putnam's construction of the civic participation into account, questions were asked of respondents that included items their actions regarding activities such as participating in a protest, attending meetings pertaining to city or school governance. Also, the respondent's ability to participate in volunteer work and ability to contribute to issues important to them.

Civic Participation

During the past 4 years, have you joined in a protest march, rally, or demonstration? ${ }^{+}$

During the past 4 years, have you attended a meeting of a town or city government or school board? ${ }^{+}$

Not counting a religious organization, during the past 4 years, have you given money to any other organization concerned with a political or social issue, or have you not done this in the past 4 years? ${ }^{+}$

During the PAST 12 MONTHS, have your worked with other people to deal with some issue facing your community? ${ }^{+}$

During the PAST 12 MONTHS, did you attend a meeting about an issue facing your community or schools? ${ }^{+}$ Many people say they have less time these days to do volunteer work. What about you, were you able to devote any time to volunteer work in the last 12 months or did you not do so? ${ }^{+}$

Many people are finding it more difficult to make contributions to church or charity as much as they used to. How about you - were you able to contribute any money to church or charity in the past 12 months? ${ }^{+}$

Do you serve as an officer or committee member in any local organization? This includes both on and off campus organizations.*

Are you a member of an organization such as hobby clubs, sports teams, community groups, groups working on political issues? This includes both on and off campus organizations.*

Note. + indicates question from ANES 2016; * indicates question from 2000 and 2006 Social Capital Benchmark Survey

For each of the civic participation questions, respondents could answer "Yes" (coded 1), "No" (coded 2) or "I don't know" (coded 3). These were then recoded into dummy variables with "Yes" remaining " 1 ," "No" now coded as " 0 ," and "I don't know recoded as "99" or missing.

\section{Religious Participation}

Putnam suggests "churches provide an important incubator for civic skills, civic norms, community interests, and civic requirement" (65-66). Also, that being religiously involved is a "strong predictor of volunteering and philanthropy" (67). Putnam looks at membership and attendance to ascertain religious participation. Also, it is necessary to ascertain religious 
contributions in order to accurately surmise the level of religious participation. The following questions were asked to create a religious participation variable.

\begin{tabular}{l}
\hline Religious Participation \\
\hline Are you a member of a local church, synagogue, or other religious or spiritual community?* \\
How often do you attend religious services?* \\
Do you participate in church activities other than attending services?* \\
$\begin{array}{l}\text { During the past } 12 \text { months, have you ever given money to a religious organization, or have you not done this in } \\
\text { the past } 12 \text { months? }\end{array}$ \\
\hline $\begin{array}{l}\text { Note. }+ \text { indicates question from ANES } 2016 ;^{*} \text { indicates question from } 2000 \text { and } 2006 \text { Social Capital Benchmark } \\
\text { Survey }\end{array}$
\end{tabular}

Respondents could select "Yes" (coded 1), "No" (2), or "I don't know" (3) to each question, except how often participant attends religious services. The "Yes/No" questions were then recoded. "Yes" (remained 1), while both "No" and "I don't know" were coded to 0. When asked if they attended religious services, respondents could answer, "Every week (or more often) (coded 1); “Almost every week (2); "Once or twice a month" (3); “A few times per year” (4); or "Less often than that" (5). These answers were recoded with "every," "almost," and "once/twice" monthly being coded as a 1; a "few times" or "less often" were coded as 0 .

\section{Informal Social Connections}

Putnam contends that individuals can either be schmoozers or machers. Schmoozers engage with friends while machers are getting together with other citizens (2000). He finds that Americans "get together with friends about twice as often as we attend organized meetings, we hang out in bars about three times as often as we work on community projects," thus suggesting we are schmoozers (98). In order to gauge this the following questions were asked.

\begin{tabular}{l}
\hline Informal Social Connections \\
\hline $\begin{array}{l}\text { How often have you had friends over to your home, apartment or dorm room in the past } 12 \text { months?* } \\
\text { How often have you visited a friend's home, apartment or dorm room in the past } 12 \text { months?* }\end{array}$ \\
$\begin{array}{l}\text { Note. }+ \text { indicates question from ANES } 2016 ; *^{*} \text { indicates question from } 2000 \text { and } 2006 \text { Social Capital Benchmark } \\
\text { Survey }\end{array}$ \\
\hline
\end{tabular}


For each of these questions, respondents could answer, "Never did this" (coded 1); "Once" (2); "A few times" (3); "2-4 times" (4); "5-9 times" (5); "About once a month on average" (6); "Twice a month" (7); "About once a week on average" (8); "More than once a week" (9). These responses were then recoded with "never did this" as a 0 and all other values shifting down one place.

\section{Trust - (individual versus institutional)}

When measuring trust, it is important to note what type of trust is being measured. Is the trust measured on an individual level (i.e. trust in your neighbors) or institutional level (i.e. trust in your local government)? Engbers et al. note that studies typically focus on one type; however, Hakhverdian and Mayne (2012) measure institutional level trust, while controlling for individual level trust. Putnam's (2000) social trust is more in line with the level of individual trust that I will measure. The following questions were asked and specifically sought to address both forms of trust.

\begin{tabular}{|l|}
\hline Trust \\
\hline Institutional: \\
How often can you trust the federal government in Washington to do what is right? $?^{+}$ \\
How much of the time do you think you can trust the local government to do what is right?* \\
Individual: \\
How often can people be trusted? ${ }^{+}$ \\
How often can you trust someone of a different race than you?* \\
How often can you trust someone in your neighborhood or on campus residential community?* \\
\hline $\begin{array}{l}\text { Note. }+ \text { indicates question from ANES } 2016 \text {; }^{*} \text { indicates question from } 2000 \text { and } 2006 \text { Social Capital Benchmark } \\
\text { Survey }\end{array}$ \\
\hline
\end{tabular}

For each of these questions, respondents could select "Always" (originally coded 1); "Most of the time" (2); "About half the time" (3); "Some of the time" (4); and "Never" (5). These were then recoded to in a reverse order with "Never" being recoded "0" and "Always" (4). 
Table 3.2 Social Capital Means Comparison for Experiential Education Types Pre and Post Test

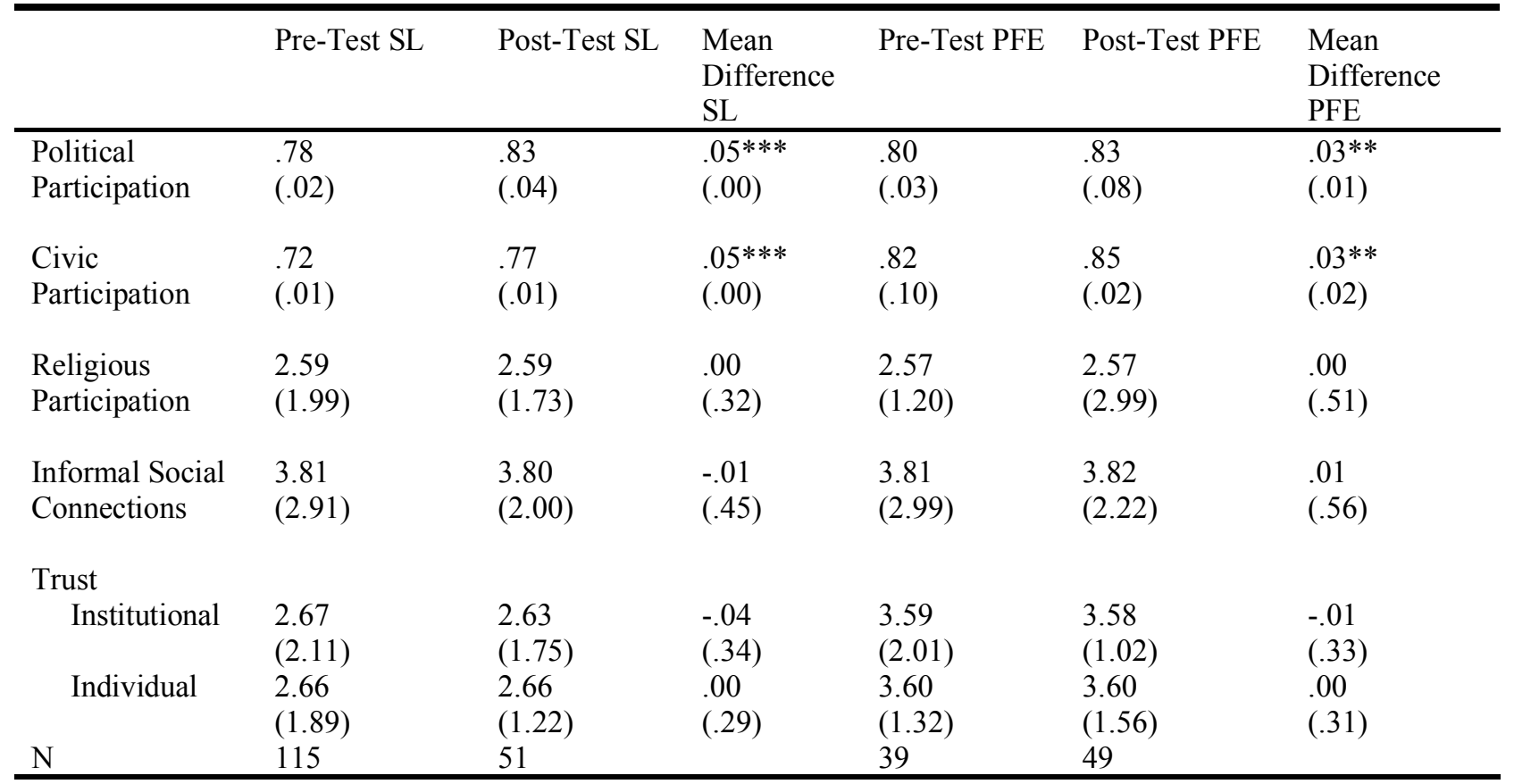

Note. Standard errors are reported in parenthesis. A two-tailed T-test was run on the difference of means and is provided in the mean difference column for service-learning and professional field experience. Two-tailed significance tests: $* \mathrm{p}<.10, * * \mathrm{p}<.05, * * * \mathrm{p}<.01$.

Table 3.2 shows pre-test means for service-learning and professional field experience in columns 2 and 5. Additionally, post-test means are reflected in columns 3 and 6 . There is a noticeable difference in pre and posttest means in both the pre and post test samples for political and civic participation. A two-tailed T-test reveals that the difference in means, reflected in columns 4 and 7, is statistically significant for political and civic participation in both the service-learning and professional field experience samples. This appears to be in direct support of the notion that Hunter and Brisbin argue about using experiential education to increase some civic education and potential action in students. There appears to be no noticeable difference in means for religious participation, informal social connections, or either type of trust.

\section{Bridging and Bonding Social Capital Variables}

Putnam details the difference between bridging and bonding social capital. Bridging is inclusive, while bonding is exclusive. Bonding is typically more "inward looking" and bridging 
is important for "linkage to external assets" (21-22). Putnam argues that both are important but that bridging social capital helps one to "look ahead" (22). However, he also mentioned that he had not yet identified a reliable survey that measured bridging and bonding.

As a result of the lack of surveying ability, Williams (2006) develops a bridging and bonding measure to assess how being online/offline predicts a respondent's bridging social capital. Ellison et al. (2014) build on these variables to incorporate Facebook into this understanding. While the purpose of understanding bridging and bonding social capital is not necessarily associated with online and offline measures, it this survey questions developed by Williams and refined by Ellison make it possible to more accurately measure social capital development in an offline and online setting. Therefore, Williams' questions are used to ascertain if bridging and bonding social capital actually increases throughout the course of the semester. Questions that Williams evaluated in his factor analysis in order to come up with his bridging and bonding online and offline questions were used. 
Participants in each survey were asked how much they agreed with each statement based on a 5-point Likert scale ranging from strongly agree (coded 1); somewhat agree (2); neither agree nor disagree (3); somewhat disagree (4); strongly disagree (5). These were recoded in reverse order as such: strongly agree (coded 5); somewhat agree (4); neither agree nor disagree (3); somewhat disagree (2); strongly disagree (1).

Table 3.3 Bridging and Bonding Social Capital Means Comparison for Experiential Education Types Pre- and Post-Test

\begin{tabular}{lllllll}
\hline & Pre-Test SL & Post-Test SL & $\begin{array}{l}\text { Mean } \\
\text { Difference } \\
\text { SL }\end{array}$ & Pre-Test PFE & Post-Test PFE & $\begin{array}{l}\text { Mean } \\
\text { Difference } \\
\text { PFE }\end{array}$ \\
\hline $\begin{array}{l}\text { Bridging Social } \\
\text { Capital }\end{array}$ & 4.07 & 4.10 & .03 & 4.66 & 4.10 & -.56 \\
& $(2.99)$ & $(1.29)$ & $(.44)$ & $(3.01)$ & $(2.52)$ & $(.59)$ \\
Bonding Social & 3.99 & 4.09 & .10 & 4.70 & 4.77 & .07 \\
Capital & $(3.10)$ & $(2.75)$ & $(.50)$ & $(1.02)$ & $(2.22)$ & $(.38)$ \\
$\mathrm{N}$ & 115 & 51 & & 39 & 49 & \\
\hline
\end{tabular}

Note. Standard errors are reported in parenthesis. A two-tailed T-test was run on the difference of means and is provided in the mean difference column for service-learning and professional field experience. Two-tailed significance tests: ${ }^{*} \mathrm{p}<.10,{ }^{* *} \mathrm{p}<.05, * * * \mathrm{p}<.01$.

Table 3.3 not show a substantial change in pre- and post-test means for bridging or bonding social capital. This too suggests that students may not be experiencing any form of social capital development so quickly after completing their experiential education. This makes the research addressed in chapter four all the more important. If a student does experience some increase in their scores, will it eventually manifest itself, at least once a student matriculates out of the university? That is the hope, at least when trying to understand if experiential education provides a good means of creating better citizens.

However, based on the modeling and means comparison, it is clear that hypothesis 2 is already suspect, and in danger of being rejected. What can be assumed is that the relationship is not positive, but it is possible that there is no relationship because students have not realized the social capital benefits that were being sought after by educators.

Tables 3.4 and 3.5, in the following results section, display OLS regression results 
highlighting the increase in social capital variable and bridging/bonding scores from pre and post test surveys. Table 3.4 focuses specifically on experiential education and the aforementioned variables used to evaluate social capital. Table 3.5 displays results for bridging and bonding social capital score increases from pre and post test for each type of experiential education.

\section{Qualitative Variable Construction and Explanation}

As mentioned, Smith (2006) argues that it is not possible to see noticeable results in quantitative measures when evaluating experiential education. Still, Harris (2010) does note some change in a student's own perception of the civic education and ability to apply that education. Furthermore, new research suggests that "good education requires student experiences that deliver lessons about practice as well as theory and that encourages students to work for the public good-especially in the operation of democratic institutions" (Mann et al. 2018, 832). In this study, participants "were given open-ended prompts to report the best part of their experiences, the worst part, and the most important lesson learned" $(2018,834)$. While Mann et al. note that the interpterion of open-ended responses is "ambiguous" per Roberts et al. (2014), they surmise that producing word clouds of these responses shows that "student experiences were consistent with...pedagogical goals" (2018, 834-835).

Following the research of Mann et al (2018), a software program called "Wordle" available for free at wordle.net was used to create word clouds. The responses to the open-ended questions are placed into a textbox and word clouds are produced. These clouds were either limited to 25 words or 50 words to create the cloud, depending on the number of responses for each. The open-ended responses for those in a service-learning course provided approximately $25 \%$ as many characters as those in the professional field experience course. Therefore, the service-learning course responses limited the word clouds to 25 , and the professional field 
experience course produced word clouds with 50 of the most common words.

Word clouds (Figures 3.1 through 3.6 - presented in the subsequent results section), count the number of appearances of key words appearing in open-ended student responses, were constructed for the open-ended prompts that pertained to service-learning and professional field experience. The larger a word appears in the cloud indicates the frequency that the word was used within the responses. The only words omitted from the clouds are common English words, unless otherwise noted on the subsequent figures. Therefore, the larger the word, the more respondents used it in response to the prompts.

Following the same procedure as Mann et al., students were asked about the best and worst part of whatever experiential they participated in during the semester. The questions posed were: (1) If you completed [type of experiential education] this semester as part of one of your classes, what was the best part about that experience? If you did not do [type of experiential education] in one of your classes, you should skip this question. (2) If you completed [type of experiential education] this semester as part of one of your classes, what was the worst part about that experience? If you did not do [type of experiential education] in one of your classes, you should skip this question. (3) If you completed [type of experiential education] this semester as part of one of your classes, what did you learn as a result of that experience? If you did not do [type of experiential education] in one of your classes, you should skip this question.

\section{$\underline{\text { Results }}$}

\section{Quantitative Findings}

Table 3.4 infers a relationship does exist between exposure to both service-learning and professional field experience that would support hypothesis 1, at least in part. As mentioned, all 
service-learning respondents were coded together, and all professional field experience responses were coded together.

Table 3.4 Effect of Experiential Education on Social Capital

\begin{tabular}{|c|c|c|}
\hline & Change Pre-Test SL v Post-Test SL & $\begin{array}{l}\text { Change Pre-Test PFE v Post- } \\
\text { Test PFE }\end{array}$ \\
\hline Political Participation & $\begin{array}{l}0.11 * * * \\
(0.01)\end{array}$ & $\begin{array}{l}0.22 * * * \\
(0.03)\end{array}$ \\
\hline Civic Participation & $\begin{array}{l}0.19 * * \\
(0.02)\end{array}$ & $\begin{array}{l}0.30^{*} \\
(0.04)\end{array}$ \\
\hline Religious Participation & $\begin{array}{l}-0.03 \\
(0.22)\end{array}$ & $\begin{array}{l}-0.02 \\
(0.16)\end{array}$ \\
\hline Informal Social Connections & $\begin{array}{l}0.01 \\
(0.02)\end{array}$ & $\begin{array}{l}-0.10 \\
(0.80)\end{array}$ \\
\hline \multicolumn{3}{|l|}{ Trust } \\
\hline Institutional & $\begin{array}{l}0.03 \\
(0.03)\end{array}$ & $\begin{array}{l}0.09 \\
(0.05)\end{array}$ \\
\hline Individual & $\begin{array}{l}0.04 \\
(0.08)\end{array}$ & $\begin{array}{l}0.03 \\
(0.03)\end{array}$ \\
\hline Gender & $\begin{array}{l}-0.06 \\
(0.03)\end{array}$ & $\begin{array}{l}0.14^{*} \\
(0.06)\end{array}$ \\
\hline Age & $\begin{array}{l}0.93 \\
(0.99)\end{array}$ & $\begin{array}{l}0.05 \\
(0.03)\end{array}$ \\
\hline Race & $\begin{array}{l}0.01 \\
(0.14)\end{array}$ & $\begin{array}{l}-0.09 \\
(0.08)\end{array}$ \\
\hline Hispanic & $\begin{array}{l}0.09 \\
(0.03)\end{array}$ & $\begin{array}{l}0.10 \\
(0.88)\end{array}$ \\
\hline State of Residence & $\begin{array}{l}-0.20 \\
(.19)\end{array}$ & $\begin{array}{l}0.80 \\
(0.71)\end{array}$ \\
\hline Social Class & $\begin{array}{l}0.01 \\
(0.08)\end{array}$ & $\begin{array}{l}0.12 \\
(0.90)\end{array}$ \\
\hline Credit Hours & $\begin{array}{l}0.55^{*} \\
(0.20)\end{array}$ & $\begin{array}{l}0.48^{*} \\
(0.12)\end{array}$ \\
\hline GPA & $\begin{array}{l}0.10 \\
(0.80)\end{array}$ & $\begin{array}{l}0.82 \\
(0.55)\end{array}$ \\
\hline Major & $\begin{array}{l}0.11 \\
(0.22)\end{array}$ & $\begin{array}{l}-0.08 \\
(0.09)\end{array}$ \\
\hline Previous Experiential Education ( & & \\
\hline Community Service & $\begin{array}{l}0.11^{*} \\
(0.02)\end{array}$ & $\begin{array}{l}0.33^{*} \\
(0.04)\end{array}$ \\
\hline Service-Learning & $\begin{array}{l}0.55^{* *} \\
(0.04)\end{array}$ & $\begin{array}{l}-0.03 \\
(0.09)\end{array}$ \\
\hline Professional Field Experience & $\begin{array}{l}0.89 \\
(0.75)\end{array}$ & $\begin{array}{l}0.31 * \\
(0.01)\end{array}$ \\
\hline Internship & $\begin{array}{l}-0.33 \\
(0.22)\end{array}$ & $\begin{array}{l}0.09 \\
(0.07)\end{array}$ \\
\hline Constant & $\begin{array}{l}0.00 \\
(0.08)\end{array}$ & $\begin{array}{l}0.00 \\
(0.01)\end{array}$ \\
\hline $\mathrm{R}^{2}$ & 0.12 & 0.33 \\
\hline $\mathrm{N}$ & 166 & 88 \\
\hline
\end{tabular}

Note. Coefficients estimated using OLS and robust standard errors in parentheses. Two-tailed significance tests: ${ }^{*} \mathrm{p}<.10, * * \mathrm{p}<.05, * * * \mathrm{p}<.01$. 
Table 3.4 lends support to the hypothesis that there is significant change in values for political and civic participation in respondents for both service-learning and professional field experience. When examining service-learning, it is clear that statistical significance occurs for both of those measures of social capital. The same is true for professional field experience, though it is slightly less significant for civic participation and was significant at a $\mathrm{p}<.10$.

Although some measures of social capital, political and civic participation, indicate a positive relationship between experiential education, hypothesis one must be rejected, because all components of social capital do not see that result. Still, hypothesis 1 can be partially accepted because there are statistically significant results that suggest political and civic participation do see a marked increase between the pre and post test analysis. What this does suggest is that it may be necessary to rethink how social capital is being evaluated, especially in regard to the religious component of the variable construction. Quite possibly, students may not show an increase in those measures because it is unlikely that they would engage in those activities regardless of any introduced stimuli. 
Table 3.5 Effect of Experiential Education on Bridging and Bonding Social Capital

\begin{tabular}{|c|c|c|}
\hline & Change Pre-Test SL v Post-Test SL & $\begin{array}{l}\text { Change Pre-Test PFE v Post- } \\
\text { Test PFE }\end{array}$ \\
\hline Bridging Social Capital & $\begin{array}{l}0.34 \\
(0.28)\end{array}$ & $\begin{array}{l}0.54 \\
(0.33)\end{array}$ \\
\hline Bonding & $\begin{array}{l}0.45 \\
(0.27)\end{array}$ & $\begin{array}{l}0.76 \\
(0.55)\end{array}$ \\
\hline Gender & $\begin{array}{l}0.62 \\
(0.66)\end{array}$ & $\begin{array}{l}-0.03 \\
(0.25)\end{array}$ \\
\hline Age & $\begin{array}{l}-0.77 \\
(0.52)\end{array}$ & $\begin{array}{l}0.15 \\
(0.44)\end{array}$ \\
\hline Race & $\begin{array}{l}0.96 \\
(0.10)\end{array}$ & $\begin{array}{l}0.99 \\
(0.86)\end{array}$ \\
\hline Hispanic & $\begin{array}{l}0.01 \\
(0.07)\end{array}$ & $\begin{array}{l}-0.03 \\
(0.35)\end{array}$ \\
\hline State of Residence & $\begin{array}{l}-0.02 \\
(.09)\end{array}$ & $\begin{array}{l}-0.21 \\
(0.55)\end{array}$ \\
\hline Social Class & $\begin{array}{l}0.45 \\
(0.44)\end{array}$ & $\begin{array}{l}0.23 \\
(0.50)\end{array}$ \\
\hline Credit Hours & $\begin{array}{l}0.08 \\
(0.09)\end{array}$ & $\begin{array}{l}0.82 \\
(0.72)\end{array}$ \\
\hline GPA & $\begin{array}{l}0.99 * \\
(0.10)\end{array}$ & $\begin{array}{l}0.89^{*} \\
(0.11)\end{array}$ \\
\hline Major & $\begin{array}{l}-0.22 \\
(0.27)\end{array}$ & $\begin{array}{l}0.88 \\
(0.76)\end{array}$ \\
\hline \multicolumn{3}{|c|}{ Previous Experiential Education (YES) } \\
\hline Community Service & $\begin{array}{l}0.21 \\
(0.12)\end{array}$ & $\begin{array}{l}0.25 \\
(0.41)\end{array}$ \\
\hline Service-Learning & $\begin{array}{l}0.33^{*} \\
(0.04)\end{array}$ & $\begin{array}{l}0.65 \\
(0.49)\end{array}$ \\
\hline Professional Field Experience & $\begin{array}{l}0.99 \\
(0.57)\end{array}$ & $\begin{array}{l}0.33 * * \\
(0.07)\end{array}$ \\
\hline Internship & $\begin{array}{l}0.21 \\
(0.19)\end{array}$ & $\begin{array}{l}0.28^{*} \\
(0.02)\end{array}$ \\
\hline Constant & $\begin{array}{l}0.00 \\
(0.12)\end{array}$ & $\begin{array}{l}0.00 \\
(0.08)\end{array}$ \\
\hline $\begin{array}{l}\mathrm{R}^{2} \\
\mathrm{~N}\end{array}$ & $\begin{array}{l}0.04 \\
166\end{array}$ & $\begin{array}{l}0.07 \\
88\end{array}$ \\
\hline
\end{tabular}

Note. Coefficients estimated using OLS and robust standard errors in parentheses. Two-tailed significance tests: ${ }^{*} \mathrm{p}<.10,{ }^{* *} \mathrm{p}<.05,{ }^{* * *} \mathrm{p}<.01$.

Table 3.5 suggests that bridging and bonding are not developed through the use of experiential education, at least when the survey measures scores at the end of the semester (Chapter 4 will address more long-term implications). Within this modeling, GPA is marginally statistically significant, indicating a higher GPA leads to higher bridging and bonding social capital scores. This is true for both types of experiential education in the sample. One area that 
will require future research is the significance of previous service-learning on building bridging and bonding capital within the service-learning sample. Also, previous professional field experience is significant within the model on the professional field experience sample. Both of these findings suggest similar findings shown in Table 3.4. Specifically, previous exposure to experiential education has a positive impact on a student's development of social capital.

Based on the results presented in Table 3.5, hypothesis 2 must be rejected in its entirety. There does appear to be a positive relationship between bridging and bonding scores with both types of experiential education; however, it is not statistically significant. Chapter 6 will address what this means for educators seeking to develop teaching strategies for engaging students in activities, both inside and outside the classroom, that will help develop students into citizens.

Qualitative Findings

The biggest differences in the word clouds centers around what students learned. While service-learning students mentioned community and helping, students in the professional field experience setting noted words that were more career focused such as "skills," "speaking," and "work." Professional field experience responses center on ideas of career readiness and application of their skills; while, service-learning focuses more on what students learned about their communities. This suggests that both forms of experiential education have different goals. Therefore, it should not be surprising to see different results and benefits for each form of experiential education.

One clear observation from the evaluating the actual responses of the open-ended questions was that students may not completely understand the difference between community service, service-learning, and professional field experience. Students seemed to answer some questions with similar answers, and it is possible that they may have been confused about what 
type of experiential education they were completing for the course. This is definitely something that needs to be addressed since course instructors may not be relaying this information effectively to the students. Furthermore, it is possible that there is no universally applied definition. As a result, one instructor may consider an action a different form of experiential education than another. There is definitely room for improvement in getting students to understand and process what type of experiential education they may asked to participate in during the semester. Also, it is possible that more universal terms need to be adopted by institutions of higher education.

To illustrate the qualitative findings within this study, 6 word clouds were produced and appear in subsequent pages.

Figure 3.1: Word cloud from "If you completed service-learning this semester as part of one of your classes, what was the best part about that experience?

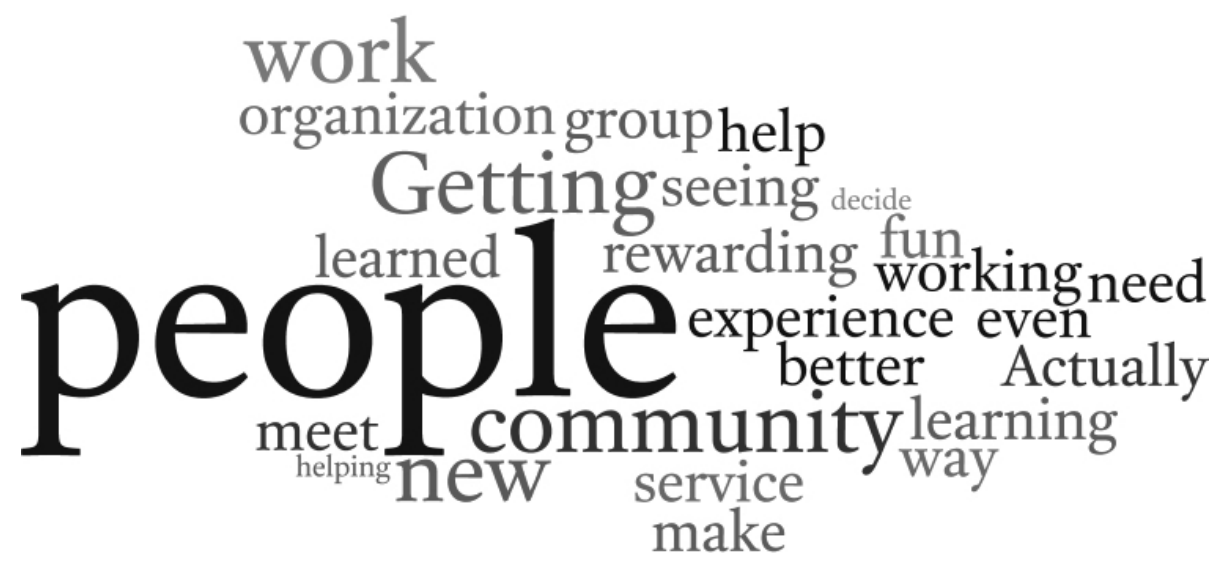

Created with software downloaded from wordle.net. Limited to 25 key words. The words "best" and "part" were omitted from this word cloud. Also, an omission was made because of language.

The responses observed in Figure 3.1 suggest that students in the service-learning courses may have developed some of the social connectivity that Putnam suggests. While these students may not have responded in a way that enabled this to be measured quantitatively, it is important to note that a large portion of the responses noted that "people" were the best part of the 
experience. This suggests that educators may be able to use service-learning as a tool to engage students in the community with people that would be considered outside their normal social group.

Figure 3.2: Word cloud from "If you completed service-learning this semester as part of one of your classes, what was the worst part about that experience?

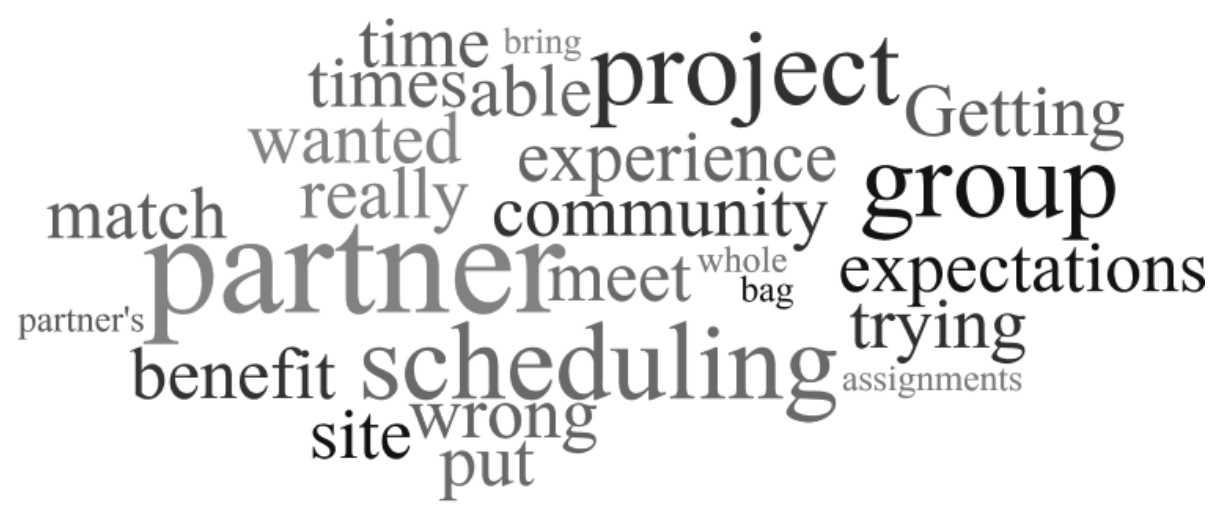

Created with software downloaded from wordle.net. Limited to 25 key words. The words "worst" and "part" were omitted from this word cloud.

As would be expected from students working in groups, it is not surprising that students noted "partner," "scheduling," and "group" as the worst part of the experience. Typically, when you I mention that their service-learning project is group based, most students exhibit a noticeable discomfort. Additionally, it is important to note that "partner" may refer to their group partners or the community partner ${ }^{5}$.

\footnotetext{
${ }^{5}$ Community partner is a term used at the university to identify an organization in the community that the students serve at during the semester.
} 
Figure 3.3: Word cloud from "If you completed service-learning this semester as part of one of your classes, what did you learn as a result of that experience?

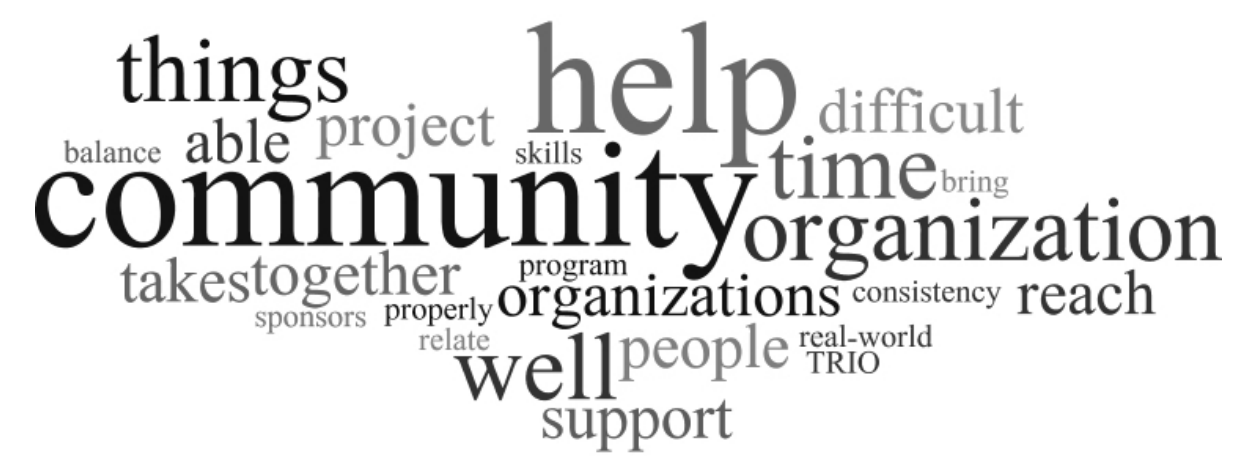

Created with software downloaded from wordle.net. Limited to 25 key words. The word "learned" was omitted from this word cloud.

Figure 3.3 suggests that students are learning more about the community in which they live. Whether that be through their interaction with community organizations or the community being served by those organizations is not evident from their responses.

It does suggest that this type of experiential education does have a positive connection with the students. These words in these clouds (Figures 3.1 and 3.3) suggest that students were able to engage with the community, suggesting that bonds/networks were formed and cultivated. This is in direct support of the Campbell's idea of "thicken[ing]" the bonds between students and communities. While the empirical data may not show that there is a noticeable change in social capital, it does suggest that students are forming those bonds within communities. Now the task becomes how to cultivate those bonds in order to actually engage students in their democracies. 
Figure 3.4: Word cloud from "If you completed professional field experience this semester as part of one of your classes, what was the best part about that experience?

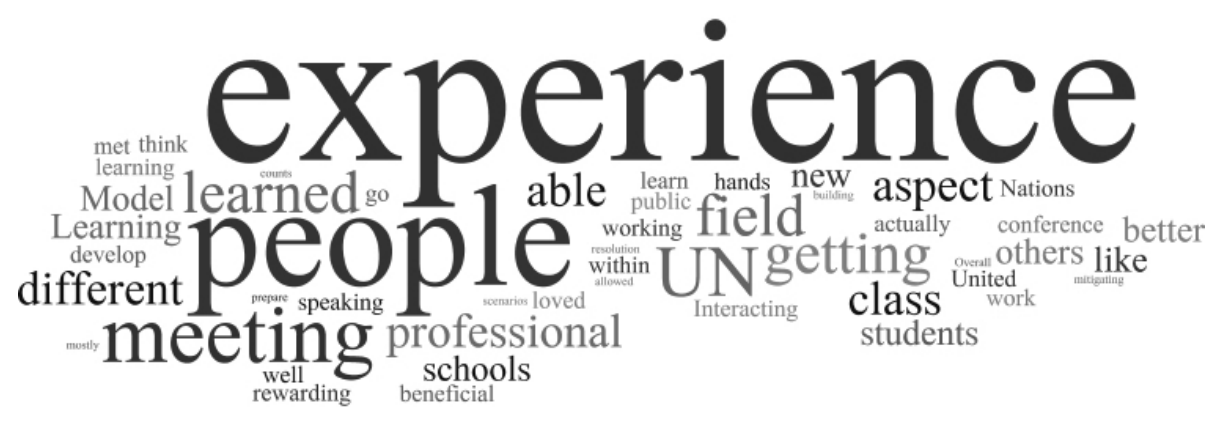

Created with software downloaded from wordle.net. Limited to 50 key words. The words "best" and "part" were omitted from this word cloud.

Responses evidenced by Figure 3.4 are what educators and proponents of experiential education would hope to observe. This suggests that a large number of respondents enjoyed the experience, though it should be noted that students may have used "experience" in their response to the question. However, words like "meeting" and "people" were still used by a higher proportion of students. This suggests that students are forming social bonds with others. It is also possible that those bonds are being formed with students who are different than them, and thus outside of their friend groups. This further solidifies the idea that experiential education is having a positive impact on students' ability to engage with others. 
Figure 3.5: Word cloud from "If you completed professional field experience this semester as part of one of your classes, what was the worst part about that experience?

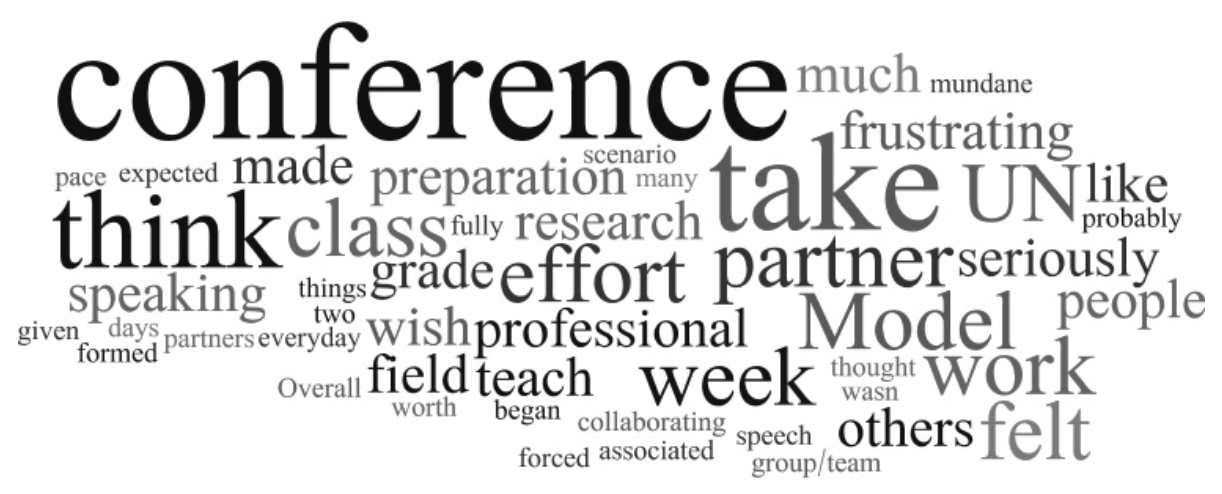

Created with software downloaded from wordle.net. Limited to 50 key words. The words "worst" and "part" were omitted from this word cloud.

When discussing the worst part (Figure 3.5) of professional field experience students used words such “conference." Since this type of experience requires attendance at a conference that students must prepare in advance for, it is not surprising that this response could be viewed negatively. However, it is no different than the response of "project" for the service-learning section. Both of these "worst" word clouds suggest that students are concerned about the actual project or conference that they must complete; however, one may be able to reason that a student would respond in similar fashion to questions regarding any class assignment. Regardless, this isn't something that would or even should dissuade educators from using MUN as part of professionalization in a student's field of study. 
Figure 3.6: Word cloud from "If you completed professional field experience this semester as part of one of your classes, what did you learn as a result of that experience?

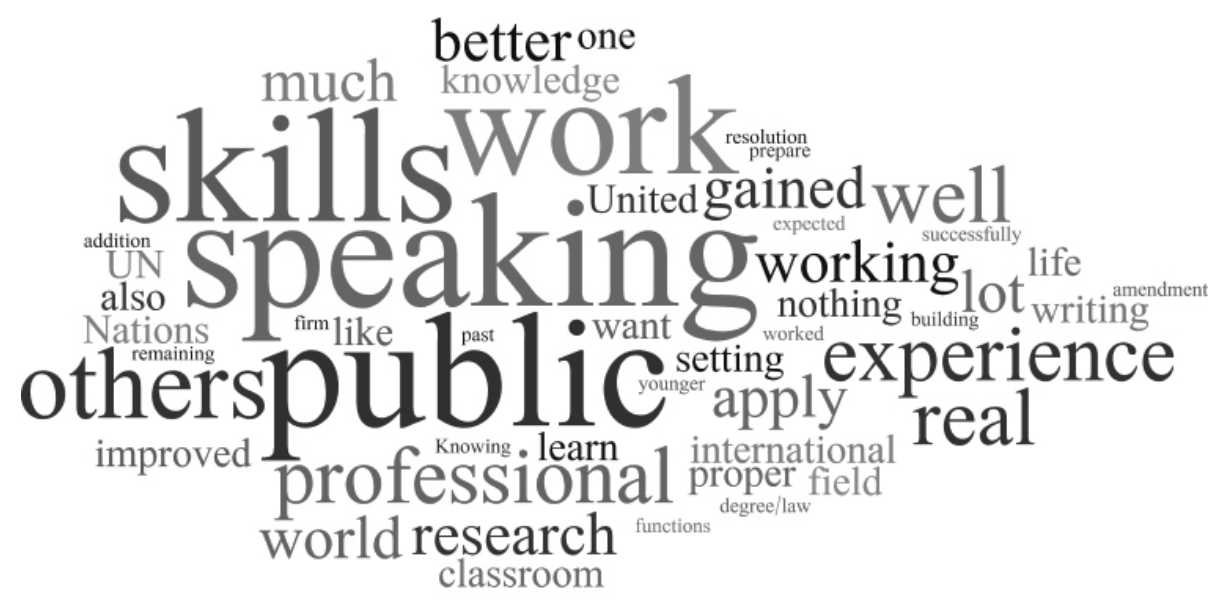

Created with software downloaded from wordle.net. Limited to 50 key words. The word "learned" was omitted from this word cloud.

As noted in the previous explanation of Figure 3.5, educators should still look to professional field experience as a valuable tool in developing a student's academic pursuits. It is evident that students involved in Model United Nations developed "skills" that can hopefully be tied to employment endeavors. Obviously "speaking” was not learned as part of this experience, but students did note in the longer responses that they enjoyed speaking to other students from around the country and from international locations. This suggests that MUN can be used by educators to help develop students professionally, while also expanding on their ability to interact with those labeled "outsiders."

\section{Conclusion}

This research suggests some elements of social capital may be positively impacted through the use of experiential education in a classroom setting. Previous research notes that experiential education cannot be used as a catchall for educators, but as tool when trying to engage students with democracy. While bridging and bonding social capital scores appear to be unaffected by the use of either service-learning or professional field experience, there is a clear 
indication that political and civic participation do increases as a result of experiential education. The consequences of this will be addressed in the concluding chapter, but it is necessary to note that this research is not altogether surprising because of previous research. What needs to be discussed in more detail is the use of certain criterion in the construction of social capital variables, especially in light of current trends evident in the behavior of higher education students as they become less religious and less likely to trust government.

However, the data presented in this chapter supports the idea that experiential education does have positive impact on political and civic participation measures in students, partially supporting hypothesis 1 . As educators seek to engage students in democracy, it is clear that service-learning and professional field experience can play a role in citizen development. Still, what is also clear is that previous exposure to experiential learning also leads to higher scores in those areas. As such, it may be necessary for experiential learning to be used in more classroom courses in order to emphasize the impact on social capital development.

The research in this chapter provides a good understanding of the limits of social capital development, that is, not all social capital measures increase. Chapter 4 examines if social capital continues to develop once a student has graduated and enters a different environment. Therefore, it should become clear if experiential education leads to increased scores on more variables that constitute social capital. 


\section{Chapter Four: The Long Road Ahead - Is There Long-Term, Identifiable Development of Social Capital in Graduates Who Participated in Experiential Education?}

This chapter is a continuation of the research presented in Chapter Three and seeks to determine if social capital continues to develop after graduation. As noted in the previous chapter, both political and civic participation increase for both forms of experiential education; however, the hypotheses suggested were not necessarily supported. While all measures of social capital did not increase, it was possible to see from the previous chapter that experiential learning does play some role in measures that typically indicate citizen development. Although the hypotheses in the previous chapter were not supported, the data suggests that development is occurring and that educators would benefit from the inclusion of different.

Perhaps those exposed to experiential education need time to reflect and internalize what is occurring before any real benefits are measurable. It is possible that those who have engaged with experiential education as students will be better primed to develop social capital after they graduate, that is, the development of social capital is a delayed response to experiential education. If this is the case, one would then expect to see continued development of social capital, ideally in all measures, and in the bridging and bonding social capital.

The effects of experiential education on student success and performance are clearly evidenced by the research conducted over the last half century. Since this research was highlighted in Chapter Three, this chapter will not rehash those findings; however, that research does serve as the justification for continuing the research in this chapter. Understanding that the ability to observe a measurable change in student attitudes and behavior during the semester he or she completes experiential education is often difficult and does not yield many results is welldocumented. Yes, there is research that underscores the importance of experiential education 
during an undergraduate class, but the research also suggests that long-term evaluations need to occur in order to recognize the full staying power of that experience.

\section{Longevity of Experiential Education Theory and Social Capital}

In light of the possibility of additional long-term effects on social capital development after exposure to experiential education, Chapter Four focuses on the social capital scores of graduates who participated in this type of education but had time to participate in democracy for longer than a semester allows to occur. Ideally, higher education institutions and educators want to see development and growth that leads a student to be a fully engaged citizen within American democracy. If a mission of the university is citizen development, it stands to reason that to be successful the development needs to continue once a student matriculates. While there are some variables that will obviously impact the ability of a graduate to continue social capital development, there is some research that suggests that the long-term effects of experiential education can be noted. In this section, the long-term effects of service-learning and professional field experience, and the research that supports those effects, will be addressed.

Mahoney and Retallick (2015) suggest that experiential learning provides students with experiences that have more practical effects than typical course-based learning. These effects would be the job skill improvement, career development, and even the ability to be prepared for a career. Furthermore, they contend that this learning is preferred by students. In addition to their findings, Fullerton, Reitenauer, and Kerrigan (2015) suggest that graduates are often able to pinpoint exactly how their skills developed. The desire to understand how students perceive an experience and how it impacted their ability to participate within their career, and hopefully democracy, are derived from this understanding. Mitchell et al. (2015) goes further and states that: 
The results of this study strongly suggest that multi-term, community engagement programs, where critical reflection is continuous and occurs in a variety of ways, support a reflective practice that persists in the lives of program graduates, helping them develop their civic and professional identities (49).

This understanding suggests that the survey instrument itself may be useful in being the reflective component that students and graduates need in order to more fully comprehend and appreciate what their experiential education was able to provide them. This is especially important to note as higher education institutions seek to engage students. Still, it is not necessarily the case that the engagement stops once a student leaves an institution and either enters the workforce or continues his or her education.

Understanding the impacts of service-learning on student learning is important, but as the previous chapter finds, it may be difficult to observe quantifiable results over the course of a semester. Therefore, it becomes necessary to think about the long-term effects of servicelearning on students. Probably the most comprehensive review of these long-term effects is a result of Fullerton, Reitenauer, and Kerrigan (2015). They argue that:

Quantitative studies suggest that college students who engaged in service-learning courses while in college were more likely to engage in community service after college (Astin et al., 2006; Astin, Sax, \& Avalos, 1999; Fenzel \& Peyrot, 2005; Wharchal \& Ruiz, 2004). Graduates who participate in service during college may attach greater significance to prosocial values such as helping others in difficulty, promoting racial understanding (Astin et al., 1999), engaging in the community, and giving charitably (Astin et al., 2006). Graduates who participated in service-learning during college also reported that the experience helped them develop leadership, teamwork, and professional communication skills (Dvorak, Stewart, Hosni, Hawkey, \& Nelson, 2011; MacFall, 2012; Newman \& Hernandez, 2011) (66).

The findings detailed in this research suggests that social capital development should be observable in graduates over time, hopefully in both the quantitative data and qualitative responses. The graduates' feelings and thoughts about what skill development occurred during 
their experience should be possible to observe in the responses to open-ended questions included in the survey.

The research that exists on the long-term impact of participation in Model United Nations is admittedly limited. This could be the result of a variety of issues. A primary reason for this lack of scholarly research is the fact that Model UN participation may be evaluated in the shortterm, but that there lacks any real motivation to continue that research once a student graduates.

The lack of generalizability in assessing these programs is a concern, but the lack of research on the topic underscores why the research must be done. In order for educators to more completely understand student learning, we must engage research that addresses what skills students develop. Chapter Three provides justification for using programs like Model UN based on responses from enrolled students, but the research on graduates needs to be conducted in order to note any tangible, real-world implications for these students and to evaluate the impact that these courses have on the development of citizens. While it is appropriate to document the skills and approaches a student develops over the course of a semester-long experience, it is equally important to determine if they continue to develop after graduation and if participants are more likely to engage in our democracy. The following research seeks to begin the examination of how and if the Model UN experience continues the development of a citizen.

While the research on service-learning and some professional field experience opportunities note the positive benefits of experiential education on graduates, there needs to be continued research on the matter in order to help educators develop those benefits. Specifically, the following research is interested in answering the following question: Does experiential education lead to learning outcome measures that continue to be developed once a student graduates? Answering this question enables one to surmise strategies to increase all measures of 
social capital; thus, making the use of experiential education all the more important in political science education.

As the previous chapter noted, the construction of the survey was built around Putnam's (2000) own construct of social capital, including measures of: political participation, civic participation, religious participation, informal social connections, and trust. The survey used in this chapter (see appendix $B$ to view survey in its entirety) was asked of graduates exposed to experiential education in pursuit of understanding if social capital scores increased once they were out of an institution of higher education. The primary focus of this survey was to offer a comparable analysis of the social capital scores of graduates who experienced various forms of experiential education during their undergraduate career.

If students were enrolled in at least one class with this type of learning, are they more or less likely to be engaged citizens? In order to ascertain a more definitive answer, the hypotheses seek to show whether service-learning or professional field impacted the social capital scores of graduates. The following hypotheses are almost identical to those asked in the previous chapter, because the goal is to ascertain whether social capital increases once a student matriculates. As was already mentioned, Chapter Three suggests that experiential education does play some role in social capital development, at least in some measures. While hypothesis one could not be completely refuted in Chapter Three, it could not be accepted either. As a result, it is necessary to see if graduates experience higher social capital scores. The following hypothesis is surmised:

$\mathrm{H}_{1}$ : Graduates who engaged in experiential education in a formal classroom setting will experience an increase in their social capital scores after graduation.

Hypothesis 2 was rejected in the previous chapter, but it is possible that graduates experience a thicken of their social networks, leading to higher bridging and bonding social capital scores. With this in mind, the following hypothesis is proposed: 
$\mathrm{H}_{2}$ : Graduates exposed to experiential education during their undergraduate education will exhibit a positive relationship on both bonding and bridging capital scores.

\section{$\underline{\text { Methods, Participants, and Study Design }}$}

The sample recruited for this survey were in a service-learning ${ }^{6}$ or professional field experience $^{7}$ course during their undergraduate tenure and graduated in 2014, 2015 or 2016. To recruit this sample, students who were completed the courses listed in Chapter Three's method section (MDS 489, LDR 201, COMM 102, and POLS 491A) were emailed the same posttest survey that students received in the spring semester of 2018. Emails for those students were provided by the university; however, it should be noted that those email addresses were assigned to students as undergraduates. Therefore, it is possible that students did not regularly check those address as they would their personal email.

For 2014, 2015, and 2016, 702 students graduated who took either MDS 489, LDR 201, or COMM 102. These courses were the service-learning courses used in Chapter Three's design. Over the same time period, 120 students graduated who were enrolled POLS 491A during their academic tenure. In order to randomly sample each of those groups, every third student listed on the email address registry was sent the survey - meaning 234 graduates had the opportunity to complete the survey who were exposed to service-learning in those classes and 40 graduates who were exposed to professional field experience through Model UN.

\footnotetext{
${ }^{6}$ Students were enrolled in MDS 489, LDR 201, or COMM 102. A further description of each course is provided in subsequent footnotes.

${ }^{7}$ Students were enrolled in a Model United Nations course, POLS491A. A further description is provided in subsequent footnotes.
} 
Table 4.1 Participation Rates of Respondents Based on Experiential Education Exposure

\begin{tabular}{llll}
\hline & Number of Responses & Participation Rate (\%) & Proportion of Survey Sample (\%) \\
\hline $\begin{array}{l}\text { Service- } \\
\text { Learning }\end{array}$ & 26 & 9.49 & 70.27 \\
& & & \\
Professional & 11 & 9.17 & 29.73 \\
$\begin{array}{l}\text { Field Exp. } \\
\mathrm{N}\end{array}$ & 37 & 13.50 & 100.00 \\
\hline
\end{tabular}

Table 4.1 illustrates the participation rate from graduates of each form of experiential education. Out of the combined 274 graduates who received the survey, 26 service-learning graduates and 11 professional field experience graduates responded to the survey. There were two responses submitted that were completely blank and were discarded. Therefore, the sample $(\mathrm{n}=37)$ of respondents participating in this survey shows a participation rate of $13.50 \%$. Of the graduates who received the survey, $9.49 \%$ responded for service-learning exposure and $9.17 \%$ responded for professional field experience exposure. Overall, there was a $13.50 \%$ response rate to the survey. Of those responses, approximately $70 \%$ were from service-learning graduates and $30 \%$ from professional field experience graduates. This is to be expected because of the higher number of graduates in the service-learning exposure category.

Similar to the surveys used in Chapter Three, respondents were asked to indicate what form of experiential education exposure they had during undergraduate in the form of various courses. These courses match up to the ones in the previous chapter, but the wording of the question was modified to indicate that the respondents would have previously taken the courses. Therefore, the question read: "In which of the following classes did you take while enrolled as an undergraduate student? Select all that apply." Participants could select the following answers: "1. COMM 112: Small Group Communication; 2. LDR 201: Principles of Leadership; 3. MDS 489: Capstone; 4. POLS 491A: Prof Fld Expr: Model U.N." Respondents indicating “1," "2," or “3” were coded as taking a service-learning course; participants responding " 4 ” were coded as taking 
a professional field development course. As Table 4.1 indicated, approximately $70 \%$ of respondents were enrolled in a service-learning course $(n=26)$, and $30 \%$ were enrolled in a professional field development course $(n=11)$. Participants in this survey completed the following questions. 
Table 4.2 Sample Characteristics

\begin{tabular}{|c|c|c|}
\hline & Service-Learning Graduates Sample & Professional Fld. Exp. Graduates Sample \\
\hline $\mathrm{N}$ & 26 & 11 \\
\hline \multicolumn{3}{|l|}{ Gender } \\
\hline Male & $34 \%$ & $29 \%$ \\
\hline Female & $66 \%$ & $71 \%$ \\
\hline Age & Mean: 26.3 & Mean 25.99 \\
\hline \multicolumn{3}{|l|}{ Race } \\
\hline White & $95 \%$ & $90 \%$ \\
\hline Black or African-Americans & $3 \%$ & - \\
\hline American Indian or Alaska & $1 \%$ & - \\
\hline \multicolumn{3}{|l|}{ Native } \\
\hline Asian & - & $10 \%$ \\
\hline Native Hawaiian or other & $1 \%$ & - \\
\hline \multicolumn{3}{|l|}{ Pacific Islander } \\
\hline \multicolumn{3}{|l|}{ Hispanic } \\
\hline No & $96 \%$ & $100 \%$ \\
\hline Yes & $4 \%$ & - \\
\hline \multicolumn{3}{|l|}{ State of Residence } \\
\hline West Virginia & $53 \%$ & $45 \%$ \\
\hline Other States/Territories & $39 \%$ & $46 \%$ \\
\hline International & $8 \%$ & $9 \%$ \\
\hline \multicolumn{3}{|l|}{ Social Class } \\
\hline Lower Class & $10 \%$ & $15 \%$ \\
\hline Working Class & $15 \%$ & $15 \%$ \\
\hline Lower Middle Class & $33 \%$ & $38 \%$ \\
\hline Upper Middle Class & $24 \%$ & $25 \%$ \\
\hline Upper Class & $18 \%$ & $7 \%$ \\
\hline \multicolumn{3}{|l|}{ Year of Graduation } \\
\hline 2014 & $22 \%$ & $30 \%$ \\
\hline 2015 & $33 \%$ & $35 \%$ \\
\hline 2016 & $45 \%$ & $35 \%$ \\
\hline \multicolumn{3}{|l|}{ GPA } \\
\hline 1.9 and below & $12 \%$ & $5 \%$ \\
\hline $2.0-2.49$ & $16 \%$ & $9 \%$ \\
\hline $2.5-2.99$ & $30 \%$ & $30 \%$ \\
\hline $3.0-3.49$ & $38 \%$ & $37 \%$ \\
\hline $3.5-4.0$ & $4 \%$ & $19 \%$ \\
\hline \multicolumn{3}{|l|}{ Major } \\
\hline Multidisciplinary Studies & $70 \%$ & $10 \%$ \\
\hline $\begin{array}{l}\text { Political Science/International } \\
\text { Studies }\end{array}$ & $15 \%$ & $80 \%$ \\
\hline Other & $15 \%$ & $10 \%$ \\
\hline \multicolumn{3}{|l|}{$\begin{array}{l}\text { Previous Experiential Education } \\
\text { (YES) }\end{array}$} \\
\hline Community Service & $80 \%$ & $88 \%$ \\
\hline Service-Learning & $95 \%$ & $30 \%$ \\
\hline Professional Field Experience & $5 \%$ & $99 \%$ \\
\hline Internship & $15 \%$ & $45 \%$ \\
\hline
\end{tabular}

Note. Not all percentages may calculate to $100 \%$ because of rounding to the nearest whole number. 


\section{Control Variables}

All of the control variables for this Chapter Two remain the same as those detailed in Chapter 3, unless noted. Gender, Age, Race, State of Residence, Social Class, GPA, Major, and Previous Experiential Education were all asked in the same manner and coded in the same way. Year of Graduation - Respondents answered "What year did you graduate from college?" They could select $2014,2015,2016$. Those responses were originally coded respectively as 1,2 , and 3; however, they were recoded as 2014 (3), 2015 (2), and 2016 (1). It should be noted that the control variable "Credit Hours" was eliminated from this survey because all respondents were graduates at the time of completing the survey; although they graduated at various intervals over the three-year span.

\section{$\underline{\text { Social Capital Variables }}$}

The social capital variables were measured using the same questions, a combination of ANES 2016 and 2000 and 2006 Social Capital Benchmark survey questions, as detailed in Chapter Three. A more detailed analysis of variable construction can be found in that chapter. However, as Table 4.3 illustrates, social capital was measured using political, civic, and religious participation, informal social connections, and institutional and individual trust. 


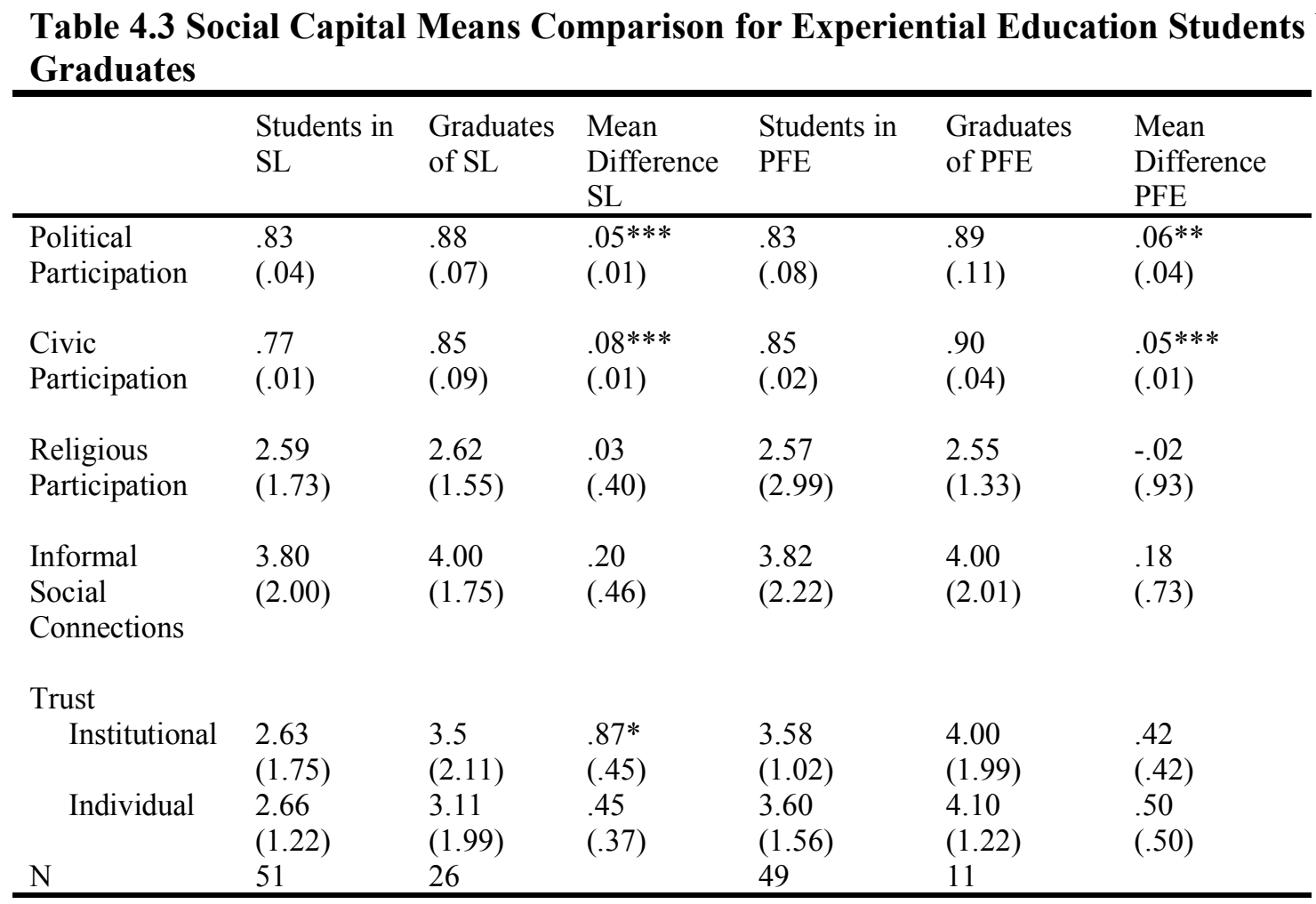

Note. Standard errors are reported in parenthesis. A two-tailed T-test was run on the difference of means and is provided in the mean difference column for service-learning and professional field experience. Two-tailed significance tests: ${ }^{*} \mathrm{p}<.10,{ }^{* *} \mathrm{p}<.05,{ }^{* * *} \mathrm{p}<.01$.

Table 4.3 shows means for students at the end of the semester during which servicelearning or professional field experiences in columns 2 and 5. Columns 3 and 6 reflect the means of graduates who indicated participating in either a service-learning or professional field experience course. As was the case in Chapter Three, the difference in means for political and civic participation in both types of experiential education are significant. Again, this supports the assertion from Hunter and Brisbin that experiential education helps develop civic knowledge and willingness to participate in democracy. What's more interesting is the support that these means tests suggest for the work of Fullerton, Reitenauer, and Kerrigan (2015). It is apparent that there is some connection between a student's experiential education participation and their willingness to continue engaging in democracy, at least in political or civic ways. 
Interestingly, the institutional trust mean shows some significance in service-learning graduates. This suggests that other traditional measures of social capital do continue to increase upon graduation. In fact, with the exception of religious participation in professional field experience graduates, all other means did increase from student to graduate analysis. However, none of those were significant when evaluated using the two-tailed T-test.

\section{Bridging and Bonding Social Capital Variables}

Bridging and bonding variables were used using the same questions derived by Williams (2006), which are discussed in Chapter Three. For a more detailed explanation of variable construction, please refer to this chapter.

Table 4.4 Bridging and Bonding Social Capital Means Comparison for Experiential Education Students Versus Graduates

\begin{tabular}{lllllll}
\hline & $\begin{array}{l}\text { Students in } \\
\text { SL }\end{array}$ & $\begin{array}{l}\text { Graduates } \\
\text { of SL }\end{array}$ & $\begin{array}{l}\text { Mean } \\
\text { Difference } \\
\text { SL }\end{array}$ & $\begin{array}{l}\text { Students in } \\
\text { PFE }\end{array}$ & $\begin{array}{l}\text { Graduates of } \\
\text { PFE }\end{array}$ & $\begin{array}{l}\text { Mean } \\
\text { Difference } \\
\text { PFE }\end{array}$ \\
\hline $\begin{array}{l}\text { Bridging Social } \\
\text { Capital }\end{array}$ & $\begin{array}{l}4.10 \\
(1.29)\end{array}$ & $\begin{array}{l}4.22 \\
(2.11)\end{array}$ & $\begin{array}{l}.12 \\
(.39)\end{array}$ & $\begin{array}{l}4.10 \\
(2.52)\end{array}$ & $\begin{array}{l}4.55 \\
(2.86)\end{array}$ & .45 \\
Bonding Social & 4.09 & 4.33 & .24 & 4.77 & 4.80 & .03 \\
$\begin{array}{l}\text { Capital } \\
\mathrm{N}\end{array}$ & $(2.75)$ & $(2.09)$ & $(.39)$ & $(2.22)$ & $(.90)$ & $(.04)$ \\
\hline $\begin{array}{l}\text { Note. Standard errors are reported in parenthesis. A two-tailed T-test was run on the difference of } \\
\text { means and is provided in the mean difference column for service-learning and professional field }\end{array}$ \\
experience. Two-tailed significance tests: *p $<.10, * * \mathrm{p}<.05, * * * \mathrm{p}<.01$.
\end{tabular}

Again, as the results in Chapter Three suggest, there is no significance in means for bridging or bonding social capital when comparing students at the end of the semester during which experiential education was used and graduates who were in courses where experiential education was used. There was an increase in all means, but nothing that was significant, and there is a fairly high stand error for each mean. However, it should be noted that all means are above a 4.0, suggesting that bridging and bonding social capital scores are already high in 
students and graduates. As such, it is possible that there is no significant increase because the scores are already so high.

Tables 4.5 and 4.6, in the following results section, display OLS regression results highlighting the increase in social capital variable and bridging/bonding scores from respondents at the end of a semester using experiential education versus graduates who indicated that they used were exposed to experiential education during their undergraduate career. Table 4.5 focuses specifically on experiential education and the aforementioned variables used to evaluate social capital. Table 4.6 displays results for bridging and bonding social capital score increases from undergraduate to graduated based on the type of experiential education.

\section{Qualitative Variable Construction and Explanation}

Using the same methodology described in Chapter Three, Figures 4.1 through 4.6 were created. The same questions were asked, though slightly modified to represent the fact that respondents were reflecting upon their time in undergrad. Therefore, the questions read: "If you completed [type of experiential education] while enrolled as an undergraduate student as part of one of your classes, what was the best part about that experience?"; "If you completed servicelearning while enrolled as an undergraduate student as part of one of your classes, what was the worst part about that experience?"; and "If you completed service-learning while enrolled as an undergraduate student as part of one of your classes, what did you learn as a result of that experience?" The same procedure detailed in the previous chapter was used to create the clouds in regard to the words omitted from responses. 


\section{$\underline{\text { Results }}$}

\section{Quantitative Findings}

Table 4.5 infers a relationship exists between exposure to both service-learning and professional field experience, that would again support hypothesis 1, at least in part. Remember this is the same conclusion reached in Chapter Three. It is important to note, that simply because the hypothesis is not completely supported, does not mean that some elements of social capital are being developed. A discussion of that follows Table 4.5. Table 4.6 infers that no relationship exists between bridging and bonding variables in relation to either form of experiential education. As a result, hypothesis 2 must be rejected. This is the same conclusion that the reach in Chapter Three supports. 
Table 4.5 Effect of Experiential Education on Social Capital

\begin{tabular}{|c|c|c|}
\hline & Change Student SL v Graduate SL & Change Student PFE v Graduate PFE \\
\hline Political Participation & $\begin{array}{l}0.32 * * * \\
(0.07)\end{array}$ & $\begin{array}{l}0.40 * * * \\
(0.09)\end{array}$ \\
\hline Civic Participation & $0.24 * *$ & $0.25^{* *}$ \\
\hline & $(0.03)$ & $(0.05)$ \\
\hline Religious Participation & $\begin{array}{l}-0.01 \\
(0.31)\end{array}$ & $\begin{array}{l}-0.08 \\
(0.22)\end{array}$ \\
\hline Informal Social Connections & $\begin{array}{l}0.22 \\
(0.15)\end{array}$ & $\begin{array}{l}-0.22 \\
(0.33)\end{array}$ \\
\hline \multicolumn{3}{|l|}{ Trust } \\
\hline Institutional & $\begin{array}{l}0.56 \\
(0.75)\end{array}$ & $\begin{array}{l}0.72 \\
(0.34)\end{array}$ \\
\hline Individual & $\begin{array}{l}0.02 \\
(0.10)\end{array}$ & $\begin{array}{l}0.24 \\
(0.21)\end{array}$ \\
\hline Gender & $\begin{array}{l}-0.22 * \\
(0.10)\end{array}$ & $\begin{array}{l}-0.19 \\
(0.06)\end{array}$ \\
\hline Age & $\begin{array}{l}0.44 \\
(0.27)\end{array}$ & $\begin{array}{l}0.25 \\
(0.35)\end{array}$ \\
\hline Race & $\begin{array}{l}0.22 \\
(0.22)\end{array}$ & $\begin{array}{l}0.10 \\
(0.08)\end{array}$ \\
\hline Hispanic & $\begin{array}{l}0.00 \\
(0.01)\end{array}$ & $\begin{array}{l}0.06 \\
(0.01)\end{array}$ \\
\hline State of Residence & $\begin{array}{l}-0.65 \\
(.55)\end{array}$ & $\begin{array}{l}0.44 \\
(0.10)\end{array}$ \\
\hline Social Class & $\begin{array}{l}-0.11 \\
(0.08)\end{array}$ & $\begin{array}{l}-0.43 \\
(0.55)\end{array}$ \\
\hline Graduation Year & $\begin{array}{l}0.54 * \\
(0.09)\end{array}$ & $\begin{array}{l}0.99 * \\
(0.07)\end{array}$ \\
\hline GPA & $\begin{array}{l}0.25 * \\
(0.10)\end{array}$ & $\begin{array}{l}0.44 * \\
(0.03)\end{array}$ \\
\hline Major & $\begin{array}{l}-0.05 \\
(0.23)\end{array}$ & $\begin{array}{l}0.11 \\
(0.15)\end{array}$ \\
\hline Previous Experiential Education () & & \\
\hline Community Service & $\begin{array}{l}0.99 * \\
(0.08)\end{array}$ & $\begin{array}{l}0.77^{*} \\
(0.14)\end{array}$ \\
\hline Service-Learning & $\begin{array}{l}0.44^{*} \\
(0.11)\end{array}$ & $\begin{array}{l}0.13 \\
(0.11)\end{array}$ \\
\hline Professional Field Experience & $\begin{array}{l}0.10 \\
(0.09)\end{array}$ & $\begin{array}{l}0.33^{*} \\
(0.09)\end{array}$ \\
\hline Internship & $\begin{array}{l}0.29 \\
(0.19)\end{array}$ & $\begin{array}{l}0.17 \\
(0.20)\end{array}$ \\
\hline Constant & $\begin{array}{l}0.00 \\
(0.06)\end{array}$ & $\begin{array}{l}0.00 \\
(0.04)\end{array}$ \\
\hline $\mathrm{R}^{2}$ & 0.24 & 0.27 \\
\hline $\mathrm{N}$ & 77 & 60 \\
\hline
\end{tabular}

Note. Coefficients estimated using OLS and robust standard errors in parentheses. Two-tailed significance tests: ${ }^{*} \mathrm{p}<.10$, $* * \mathrm{p}<.05, * * * \mathrm{p}<.01$. 
As in the previous chapter, both political and civic participation show a statistically significant change in values. This is important because it suggests that students continue to build certain elements of social capital after being exposed to both types of experiential education. In both models, political participation increases between the exposure and the respondents taking the survey. Political participation is also the variable that is the most significant and suggests that students and then graduates increase their political participation as a result of experiential education. Furthermore, civic participation also increases, although with a slightly lower statistical significance. However, both of these would indicate that experiential education does lead to an increase in both political and civic participation, at least somewhat supporting the hypothesis 1 . However, as was shown in Chapter Three, hypothesis 1 cannot be accepted in its entirety, because all variables that measure social capital do not increase. Still, if political science educators are attempting to create better citizens, it is not difficult to see that engaging those students with political and civic actions may do just that. 
Table 4.6 Effect of Experiential Education on Bridging and Bonding Social Capital

\begin{tabular}{|c|c|c|}
\hline & Change Student SL v Graduate SL & Change Student PFE v Graduate PFE \\
\hline Bridging Social Capital & $\begin{array}{l}0.25 \\
(0.39)\end{array}$ & $\begin{array}{l}0.44 \\
(0.22)\end{array}$ \\
\hline Bonding & $\begin{array}{l}0.23 \\
(0.15)\end{array}$ & $\begin{array}{l}0.54 \\
(0.33)\end{array}$ \\
\hline Gender & $\begin{array}{l}0.55 \\
(0.31)\end{array}$ & $\begin{array}{l}-0.09 \\
(0.08)\end{array}$ \\
\hline Age & $\begin{array}{l}-0.99 \\
(0.34)\end{array}$ & $\begin{array}{l}0.14 \\
(0.53)\end{array}$ \\
\hline Race & $\begin{array}{l}0.48 \\
(0.50)\end{array}$ & $\begin{array}{l}0.87 \\
(0.19)\end{array}$ \\
\hline Hispanic & $\begin{array}{l}0.01 \\
(0.01)\end{array}$ & $\begin{array}{l}-0.39 \\
(0.45)\end{array}$ \\
\hline State of Residence & $\begin{array}{l}-0.88 \\
(.22)\end{array}$ & $\begin{array}{l}-0.22 \\
(0.04)\end{array}$ \\
\hline Social Class & $\begin{array}{l}0.37 \\
(0.12)\end{array}$ & $\begin{array}{l}0.10 \\
(0.09)\end{array}$ \\
\hline Graduation & $\begin{array}{l}0.33 \\
(0.21)\end{array}$ & $\begin{array}{l}0.77 \\
(0.32)\end{array}$ \\
\hline GPA & $\begin{array}{l}0.22 * \\
(0.02)\end{array}$ & $\begin{array}{l}0.99 * \\
(0.25)\end{array}$ \\
\hline Major & $\begin{array}{l}-0.88 \\
(0.75)\end{array}$ & $\begin{array}{l}0.33 \\
(0.72)\end{array}$ \\
\hline \multicolumn{3}{|c|}{ Previous Experiential Education (YES) } \\
\hline Community Service & $\begin{array}{l}0.78^{* *} \\
(0.02)\end{array}$ & $\begin{array}{l}0.41 * * \\
(0.41)\end{array}$ \\
\hline Service-Learning & $\begin{array}{l}0.48^{*} \\
(0.07)\end{array}$ & $\begin{array}{l}0.77 \\
(0.53)\end{array}$ \\
\hline Professional Field Experience & $\begin{array}{l}0.15 \\
(0.45)\end{array}$ & $\begin{array}{l}0.93 * * \\
(0.10)\end{array}$ \\
\hline Internship & $\begin{array}{l}0.18 \\
(0.09)\end{array}$ & $\begin{array}{l}0.15^{*} \\
(0.01)\end{array}$ \\
\hline Constant & $\begin{array}{l}0.00 \\
(0.07)\end{array}$ & $\begin{array}{l}0.00 \\
(0.10)\end{array}$ \\
\hline $\mathrm{R}^{2}$ & 0.11 & 0.09 \\
\hline $\mathrm{N}$ & 77 & 60 \\
\hline
\end{tabular}

Table 4.6 suggests that bridging and bonding social capital are not developed through the use of either type of experiential education. Chapter Three noted that this chapter would address any long-term development of bridging and bonding social capital, but it is apparent that hypothesis 2 must again be rejected. Still, as was mentioned in the discussion of means (Table 4.4), the means for bridging and bonding social capital is already very high. A mean of 5.0 
would indicate that the respondent "strongly agrees" with the statement and that they would have high bridging or bonding scores. Therefore, it is possible that development does not occur because there is very little room for that development to actually occur.

It is also important to note that Table 4.6 does show some other variables to be significant. For graduates of a service-learning course, repeated exposure to community service and service-learning indicated that scores would be higher. For graduates of a professional field experience course, additional exposure to professional field experience, community service, and internships lead to higher scores. What this suggests is that the continued exposure to experiential education leads to a more fulfilling experience for students. This suggests that educators cannot use experiential education in one class with the hopes that students will automatically become more engaged in democracy. Instead, repeated attempts to expose students is necessary for citizen development.

\section{Qualitative Findings}

While the quantitative data and analysis may not have yielded results that were particularly significant or that showed predictability of the models suggested, the construction of word clouds does suggest that experiential education does provide a benefit to students; that benefit is obvious even in graduates, suggesting a long-term impact of experiential education on the development of students. The following clouds suggest that students' professional development is shaped by experiential learning, while also underscoring the idea that citizen development may be more complex than the social capital index would suggest or could measure and display.

Word clouds in this section (Figures 4.1 - 4.6) count the number of appearances of key words in open-ended graduate responses, which were constructed for the questions pertaining to 
the graduates' previous experience with experiential education while they were an undergraduate student. Common English words were omitted from the clouds, and in some instances, words were removed from the responses (noted below each figure). These clouds help to develop a qualitative understanding of perceptions of experiential education once an individual has graduated and has had more time to process the learning. This is particularly important since the research included above did not show any definitive results on the effectiveness of social capital development.

Figure 4.1: Word cloud from "If you completed service-learning while enrolled as an undergraduate student as part of one of your classes, what was the best part about that experience ${ }^{8}$

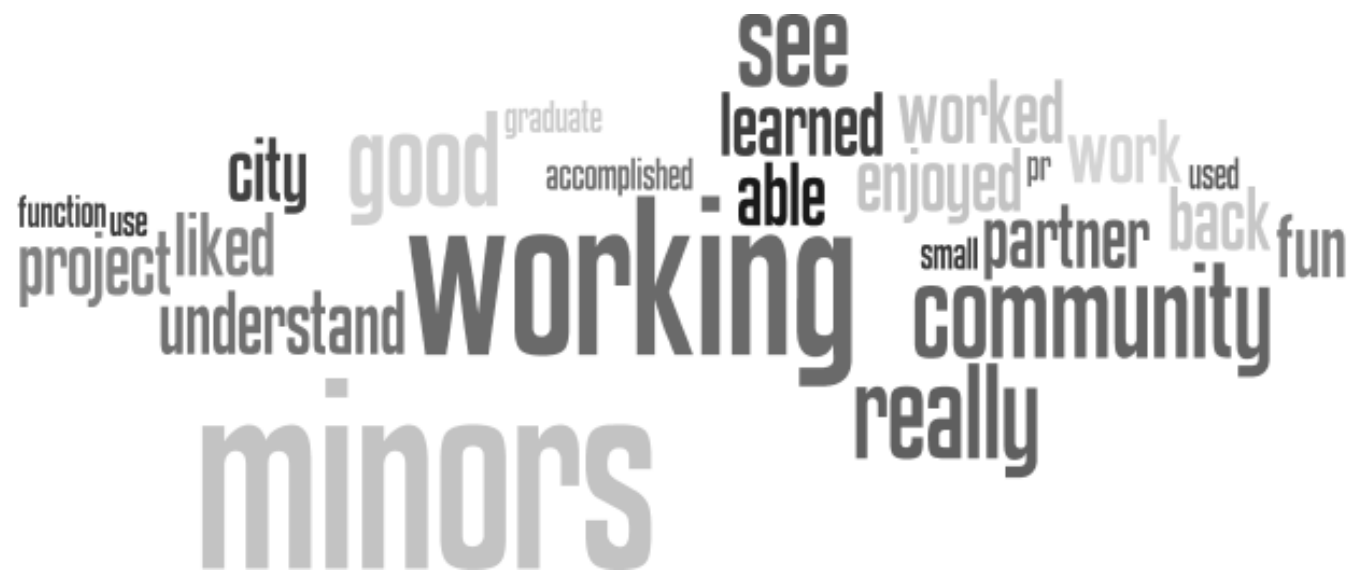

Created with software downloaded from wordle.net. Limited to 25 key words. The words "best" and "part" were omitted from this word cloud. Also, an omission was made because of language.

For this prompt, it was unsurprising that "minors" was one of the words used most often in the graduates' responses to the best part of service-learning. This is a direct result of many respondents who took the survey (20 out of 24 responses) indicating that they were an MDS student. In this particular program students select 3 fields of academic study (also known as

${ }^{8}$ These "word clouds" were produced using the graduate responses to the open-ended questions on the emailed survey. All of the clouds were constructed using the same methodology. That is, words that students used to answer the question in which they repeated a portion of the prompt question were deleted. The clouds show the 25 most common words used in response to each of these questions. 
minors) and integrate them together to form the basis for their degree. Further analysis of these responses indicated that students liked using their minors and actually seeing real-world applicability of those minors. This is important when to note for program development because it underscores the importance of experiential learning in an interdisciplinary setting. This is noted in the literature review for this chapter and suggests that graduates note the value of experiential education, especially after graduation.

Figure 4.2: Word cloud from "If you completed service-learning while enrolled as an undergraduate student as part of one of your classes, what was the worst part about that experience?

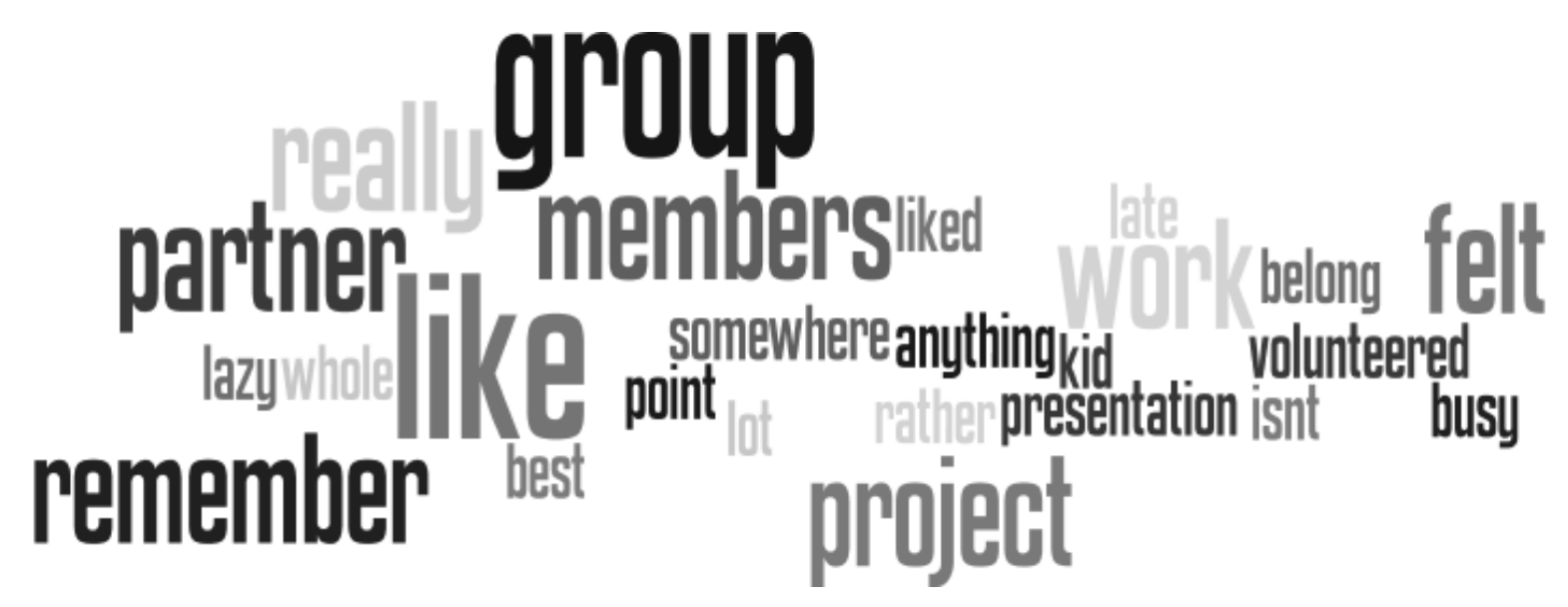

Created with software downloaded from wordle.net. Limited to 25 key words. The words "worst" and "part" were omitted from this word cloud.

As in the previous chapter, it is not surprising that alumni noted that working within a "group" and with "members" of the class was the worst part of the service-learning experience. Those seeking to address whether social connectivity is occurring within this form of experiential education may be quick to suggest it is not; however, what is most likely occurring is that students feel that group work may be unfair and that individuals may be doing more work than their peers. It would be interesting to see responses for students who perform service- 
learning independently (not identified in either Chapter Three or Four survey respondents) and perhaps this could be continued in future research.

Figure 4.3: Word cloud from "If you completed service-learning while enrolled as an undergraduate student as part of one of your classes, what did you learn as a result of that experience?

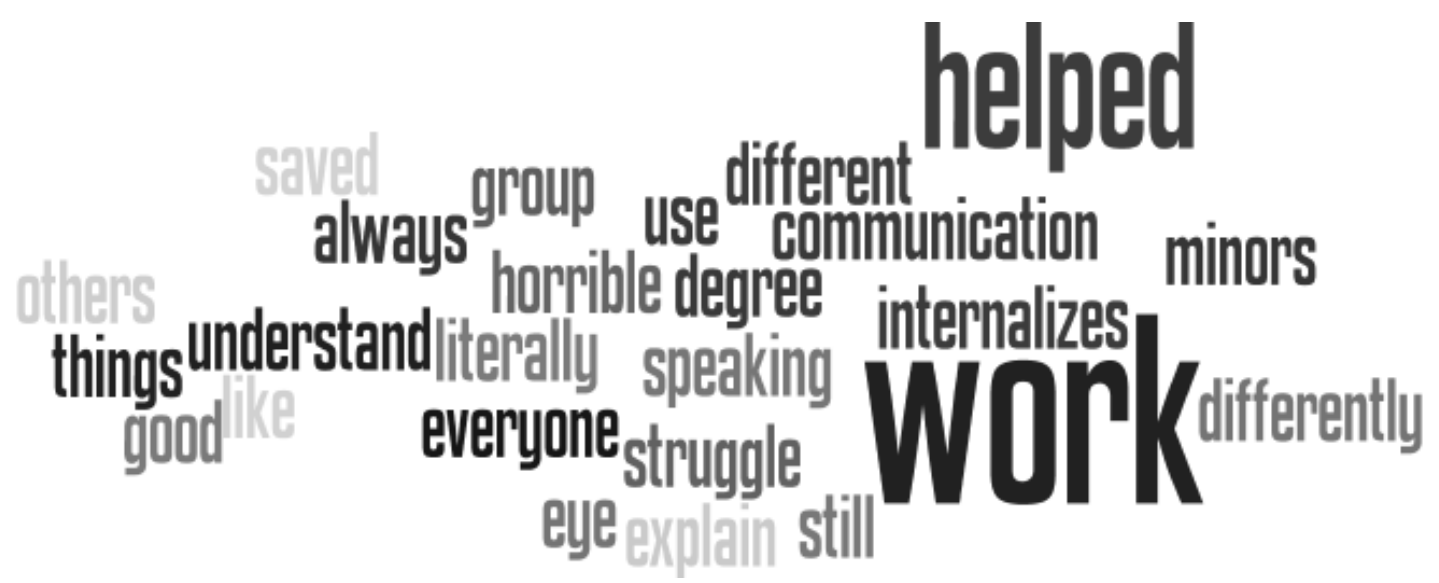

Created with software downloaded from wordle.net. Limited to 25 key words. The word "learned" was omitted from this word cloud.

Asking alumni to note what they learned harkens back to the notion that reflection is important when trying to ascertain the value of experiential education. A closer analysis of those responses indicated that they learned skills that were vital to the "work" they were now engaged in also suggested that this type of learning "helped" them to understand coursework in a way that allowed them to apply theories and concepts to situations in the workplace. As educators, this is significant and hopefully underscores the importance of experiential education. 
Figure 4.4: Word cloud from "If you completed professional field experience while enrolled as an undergraduate student as part of one of your classes, what was the best part about that experience?

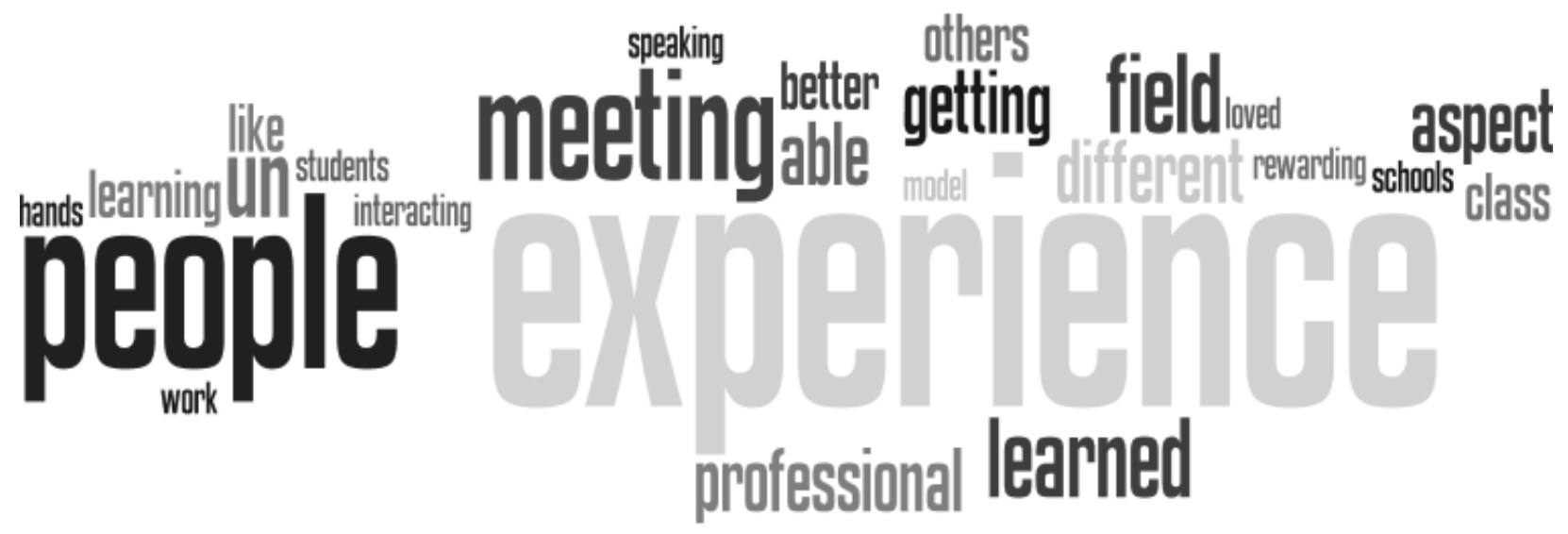

Created with software downloaded from wordle.net. Limited to 25 key words. The words "best" and "part" were omitted from this word cloud.

As one would expect for this question the responses in this cloud suggest that graduates enjoyed the "experience" because they were able to engage with "people." While experience is noted in the type of education being employed, a closer read of those responses suggests that students noted liking the experience and responded with "the best part was the whole experience." Again, this should be particularly exciting for those who employ the use of Model United Nations simulations as a core component of their students' coursework. 
Figure 4.5: Word cloud from "If you completed professional field experience while enrolled as an undergraduate student as part of one of your classes, what was the worst part about that experience?

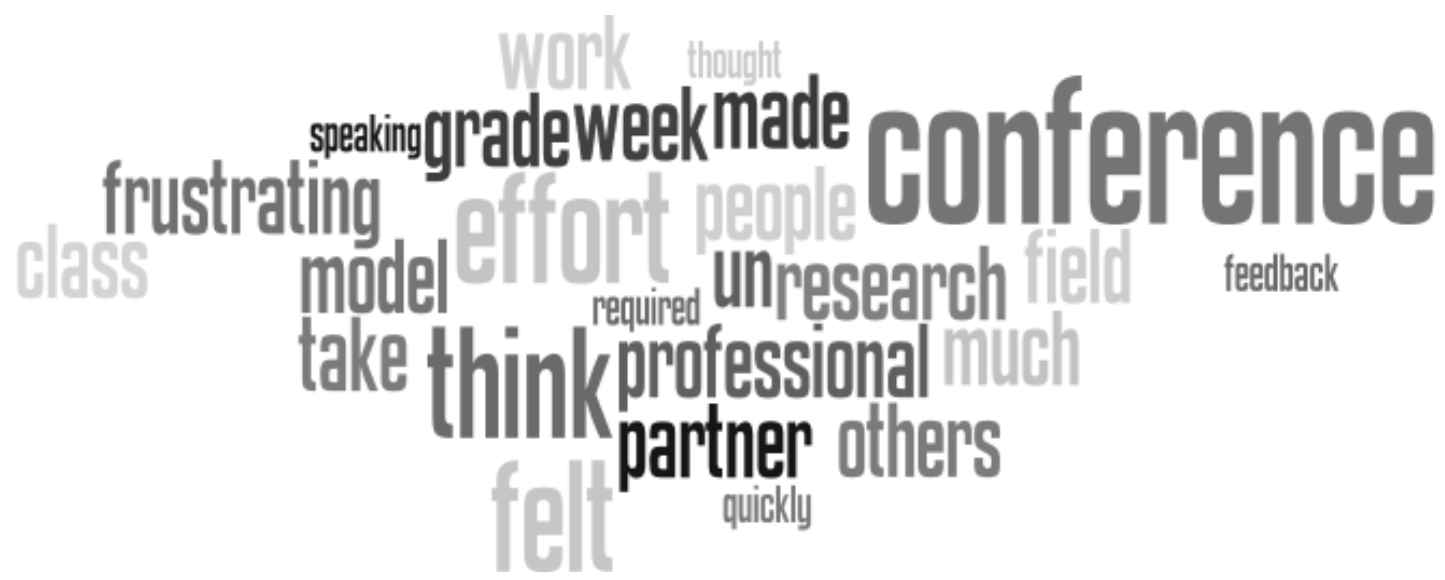

Created with software downloaded from wordle.net. Limited to 25 key words. The words "worst" and "part" were omitted from this word cloud.

As was the case in the previous chapter, graduates felt the "conference" was the worst part of the experience. This isn't to suggest that there is something inherently wrong with conference, but it does suggest that students feel like there is a lot of time and energy being devoted to conference. Also, as an instructor and advisor for MUN, I can affirm that conference days are long and tiring for students. This doesn't diminish the students' ability to learn at conference, but it only reaffirms why "conference" was the word most often used to describe the worst part of professional field experience. 
Figure 4.6: Word cloud from "If you completed professional field experience while enrolled as an undergraduate student as part of one of your classes, what did you learn as a result of that experience?

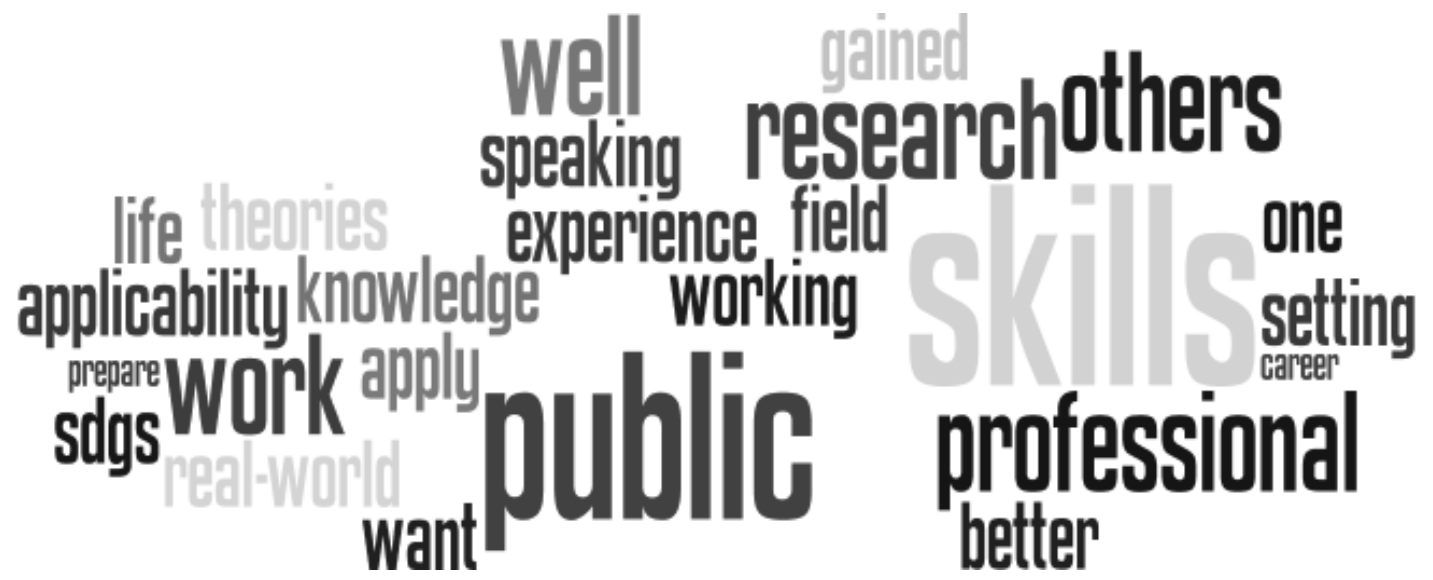

Created with software downloaded from wordle.net. Limited to 25 key words. The word "learned" was omitted from this word cloud.

When identifying what they learned, alumni used descriptions like "skill” development and "public" speaking. Again, these are important for educators as we seek to find new, inventive ways to engage students in course materials. While these may not necessary correspond to civic development, they do suggest that students are developing skills necessary to make them better engaged citizens. Being a good citizen isn't merely voting or participating, but it's how, as a citizen, you engage with your community. There is no question that professional field experience has aided alumni in their ability to engage with the community because of the skill development that has resulted because of their participation in Model UN.

The following are longer responses to the prompt - "Why would you recommend a service-learning based course to another student." The responses are included in their entirety to show the complexities of experiential education and that students have the ability to learn valuable skills that may be creating better citizens, even if the empirical data does not support that conclusion. For example, one respondent, an MDS major as an undergraduate, wrote the following in response to recommending service-learning to current students: 
One of the best experiences I had in capstone was my service-learning project. I really enjoyed the opportunity to work with a local non-profit that actually focused on an issue that I was interested in. To be honest the reputation for these projects in MDS is not great. Some of my fraternity brothers told me it was basically a joke. From my experience I really got to understand what the non-profit do [sic] and I was able to incorporate my minors into something that I cared about. Today I remember that project and think about my experiences with the people and how I really learned a lot.

Another MDS graduate, suggested that the real-world applicability of service-learning was vital

to their current employment status. The graduate wrote:

In a realworld [sic] setting I didn't think service learning was important especially during the semesterr [sic]. I remember hating this project and the class...I just wanted to GRADUATE and I thought this was another dumb hoop that the university needlessly put on me. Boy was I wrong. My project put me in contact with my current employer while I was doing PR work for the project. Without this project I probably wouldn't have my current job.

The same types of responses were observed for respondents who answered the "Why would you recommend a professional field experience (MUN) based course to another student." A political science graduate asked students to think outside the box when thinking about their career goals. This graduate suggested that students not allow themselves to be categorized into a career just because of the societal expectations of a political scientist. The respondent wrote:

I think a lot of poli sci [sic] students think they want to work for the federal government and I was no different. When I graduated the "realworld" [sic] hit me fast. I worked a couple of minimum wage jobs and couldn't find employment. Now I work at a policy initiative thinktank. I think my years in Model UN helped me develop skills that I use almost everyday. I never realized I would have to work in so many groups. Being in the club helped me become a better listener and person in general.

Another graduate, an International Studies major as an undergraduate, suggested the following about his or her time in Model United Nations:

MUN was one of the most memorable experiences I had at WVU. Not only did I overcome my fear of public speaking, but I was able to form close friends with some classmates. I would say that MUN helped me understand the international community in a way that I hadn't previously thought about. SDGs became something that I still think about and try to promote. I would recommend MUN to anyone. 
These responses lend credence to the idea that experiential education is enabling students to experience real-world skill development, while also focusing on areas that are important for civic development and participation. While the quantitative portions of this chapter leave some room for interpretation in regard to the effectiveness of this type of learning, the qualitative student responses cannot be ignored. Graduates are even identifying the importance of experiential education to their learning, even outside of college.

It is clear that engagement with the community is a key takeaway from the student experience. Whether that community is being served by a non-profit or one of an international variety, or even differing opinions, it is clear that experiential learning enables students to engage in situations outside of classroom learning that are valuable and need to be continued. As institutions seek to engage students, it is important to remember these responses because they highlight the fact that students truly value an education that steps outside the bounds of traditional learning. These responses reinforce the notion that bridging and bonding social capital can be developed, but it is perhaps the metric of how those variables are measured that needs to be questioned and reinvented.

\section{Conclusion}

Much like the conclusions in Chapter Three, it is important to note that certain elements of social capital continue to be positively impacted by the use of experiential education in the classroom. While Chapter Three never meant to suggest that experiential education could be used as a failsafe for political science educators looking to create citizens, it did provide support for the use of innovative teaching techniques to aid in the development of citizens. Chapter Four continues that work, and lends credence to the idea that citizens can be developed. While this chapter did not find support for either hypothesis, what did occur is the understanding that 
citizens continue to develop social capital as they move on from their undergraduate education. What this means for political science educators and institutions of higher education will be more completely addressed in Chapter Six; however, it is important to note that political and civic participation show development during the undergraduate experience, as evidenced in chapter Three, as well as after exposure to experiential education, as detailed in this chapter.

Future research will work to expand qualitative analysis of the student experience because, as evidenced from the responses in this chapter, those responses provided a meaningful understanding of how students and graduates are developing. Actually, getting the first-hand analysis of experiential education from those who participated in it enables the research, and hopefully the institution where the education is occurring, to see the benefit in this type of learning.

As will be discussed in the concluding chapter, experiential education is not the definitive answer to citizen development or even to successful student learning. Still, experiential education does provide for some kind of student response that is different from traditional class-based instruction. Therefore, a review of the educational policies that dictate that type of learning will be useful in trying to get more buy-in from students, faculty, and institutions. Perhaps Chapters Three and Four did not definitively prove the importance of experiential learning in social capital development, but citizen development is definitely occurring. Additionally, these chapters underscore the fact that this type of learning $\boldsymbol{I S}$ engaging students. Therefore, it is valuable and a worthwhile effort on the part of political science educators and institutions of higher education. 


\section{Chapter Five: Integrating Virtual Reality in the Classroom: Bolstering Social Capital and Developing Empathy}

Chapters Three and Four were closely related in purpose - providing analysis of experiential education's implementation in a bid to understand if they foster civic engagement in students. Chapter Five, though also focused on student-centered learning, assesses how/if students develop social capital and empathy as a result supplemental video-based learning. Can video immersion encourage students to think about others in a way that could potentially lead to policy change in the future? This research is important to political science educators because it highlights the possibility that coursework alone cannot influence student perception and desire to act. Therefore, if the creation and/or development of citizens is the goal of higher education, more engaging methods of teaching may need to be considered. With that in mind, enter the idea of virtual reality.

\section{Can You See Me Now? Understanding Virtual Reality}

Virtual reality is one of the newest forms of educational endeavors employed to engage students. The similarities to experiential education discussed in the previous chapters cannot be ignored. These similarities include the ability for students to experience something that is not typical of classroom learning. However, service-learning and professional field experience expect the learner to leave the confines of the traditional classroom setting, while virtual reality does not require that additional step. Instead, students use virtual reality goggles to "experience" situations that they would not have the opportunity or perhaps desire to experience in real life. For instance, students can watch a virtual reality video that follows a young girl around a refugee camp in order to understand how men and women are treated differently in the Middle East, even in the confines of the camp.

This type of education seeks to remove students from their everyday surroundings and 
expose them to a foreign setting. While the student is not directly experiencing the events in the virtual reality video, it does help them to see what other people are going through outside of their own experiences. Virtual reality may provide a good bolster to social capital, because it may compel students to address issues that they can only see in the virtual experience. Moreover, it may help students develop empathy for those that would often be labeled as the "other." Perhaps this concern of the "other" leads to empathy development in students.

Chris Milk, founder and CEO of Within, a virtual reality company, suggests that virtual reality is the "ultimate empathy machine." But what is empathy and how is it measured? The World Economic Forum (WEF) suggests, "empathy is the ability to share and understand the emotions of others." However, empathy is not just understanding others, but understanding those outside of our ingroups. With this in mind, it seems logical to link the development of empathy with social capital. If individuals begin to develop empathy toward those in their outgroups, it stands to reason that an increase in social capital would follow. In order to measure this effect, virtual reality videos were incorporated into an Introduction to International Relations class to supplement, not replace, lectures. Instead of simply listening to lectures or viewing pictures about a particular global issue, students used virtual reality to "experience" the phenomena being discussed. The Questionnaire of Cognitive and Affective Empathy, in conjunction with Williams (2006) questionnaire on bridging and bonding social capital, provide the basis for my assessment of virtual reality on students. I am interested in whether virtual reality provides an opportunity to develop social capital. Too often students note that they may read or watch the news, but that they do not necessarily feel connected to the people or places that they encounter in news stories. Measuring how bridging and bonding social capital, as well as empathy, changes over the course 
of the semester should provide a clear understanding of whether virtual reality is a valuable tool for use in the classroom.

\section{Virtual Reality, Empathy, and Social Capital}

How do political science educators engage our students, especially when they may be talking about events or people that students are unfamiliar with, or who seemingly lack similar views and experiences of those students? Virtual reality may provide that link that educators are looking for, but what exactly is virtual reality? For some, ideas of computer animated scenes, may seem out of place, especially in a political science classroom; yet, advancements in technology has changed what the meaning of virtual reality is today. The VR used in the classrooms is rarely something that is computer generated. Instead, the videos are made in a way that films real people in real situations. How the video is made allows the viewer, who is wearing VR goggles, to feel as if they are seeing the situation play out in real time. For instance, the 2015 VR video Clouds Over Sidra ${ }^{9}$, is about the Syrian refugee crisis. The video follows a young child throughout her day. Clouds Over Sidra allows the viewer to see the experiences of this child, without actually being in this real-life situation. Therefore, when I discuss virtual reality throughout the rest of this paper it should be viewed as this type.

This chapter addresses virtual reality's ability to bolster social capital in the same way that Chapters Three and Four propose service-learning and professional field experience do, as well as the development of. empathy. This research seeks to address the following questions: What role does virtual reality play on the development of students as citizens? Can virtual reality increase empathy?

\footnotetext{
${ }^{9}$ A synopsis for each virtual reality video shown during the course are provided in Appendix D. These synopses address the content of the videos, as well as the applications used to launch and view each video and the running time.
} 
While the virtual reality used for this research is relatively new, educators have been using VR in the classroom since at least the mid-1990s. Psotka (1995) suggest that "VR needs to be developed as an integral part of the educational and training process, implemented alongside other traditional and non-traditional tools" (428). While his work deals with a more simulated reality, it is clear that drive to use VR as an educational tool has been the desire of educators for the better part of two decades. Building on this work, Hu-Au and Lee (2017) conclude that VR "can play a unique role in addressing...educational challenges" (215). They conclude that "VR is especially useful for providing several opportunities: increasing student engagement; providing constructivist, authentic experiences to impact student identity; allowing for new perspective taking and empathy; and supporting creativity and the ability to visualise (sic) difficult models" (221). This is especially important when considering that bridging and bonding social capital measures a person's willingness to build relations, both inside and outside their typical groups. If VR can be employed to develop those types of social capital, it is possible that empathy could also be taught in a classroom setting.

Another interesting point that $\mathrm{Hu}-\mathrm{Au}$ and Lee highlight is the changing nature of education. No longer can educators employ the "Industrial Revolution model of education" (216). That is, educators can no longer assume that "accumulation of information" is the top priority. Instead, the "Experience Age" causes students to want the opportunity to focus on "sharing and experiencing new points of view" (216). This presents educators with a unique opportunity to employ innovative teaching techniques in order gain the attention of their students, and hopefully have the positive benefits outlined previously.

Recalling the rationale of the hypotheses derived in Chapters Three and Four, this chapter seeks to address the ability of an innovative teaching technique as a means to increase social 
capital in students. While not experiential education as described in those chapters, the use of virtual reality is an innovative teaching technique that is employed in the classroom in order to aid in more citizen development, or at least that is the hope. As experiential education has ample research to back up assumptions made in previous chapters, the use of virtual reality in classrooms is a relatively new phenomenon. As such, these hypotheses seek to indicate if the use of virtual reality can also aid in citizen development.

$\mathrm{H}_{1:}$ Students enrolled in a course section that requires the use of virtual reality googles will have higher social capital scores than students in a non-VR section.

$\mathrm{H}_{2:}$ Students enrolled in a course section that requires the use of virtual reality googles will have higher bridging and bonding social capital scores than students in a non-VR section.

$\mathrm{H}_{3}$ : Students enrolled in a course section that requires the use of virtual reality googles will have empathy scores than students in a non-VR section.

\section{Methods, Participants, and Study Design}

The sample recruited to participate in this survey was solicited during the Fall 2017 and Spring 2018 academic semesters. Students enrolled in POLS 260 (Introduction to International Relations) were asked to complete the survey. Respondents were asked to complete a survey at the beginning of the semester before beginning any coursework and at the end of the semester, once coursework was complete. There were a total of 256 students enrolled across 6 sections of this class or 3 sections per semester. The sample $(n=130)$ of respondents participating in the survey at the beginning of each semester shows a participation rate of $50.78 \%$. The sample $(\mathrm{n}=$ 109) of respondents at the end of the both semesters shows a participation rate of $42.58 \%$.

In each survey (beginning and end of semester), respondents were asked to indicate which course they were enrolled in. During each semester, one course used a virtual reality component, while the other two sections did not use this supplemental technique. As a result, 
there were two sections using the virtual reality over two semesters, and four using a traditional lecture model over two semesters. For the pre-test, respondents were asked: "Will you use virtual reality goggles as part of your POLS 260 class?” Participants could select the following answers: "1. Yes" and "2. No." For the post-test, respondents were asked: "Did you use virtual reality goggles as part of your POLS 260 class?" Again, the responses were "1. Yes" and "2. No." These were both recoded to "Yes" (1) and "No" (0).

Over two semesters, there were 93 students enrolled in the sections that used virtual reality and 163 in the sections that did not use virtual reality. As Table 5.1 illustrates, approximately $67 \%$ of students in the sample were from the virtual reality sections and $33 \%$ from the non-VR sections. In the post-test, $69 \%$ of the sample were students in the VR sections and $31 \%$ in the non-VR sections.

\section{Table 5.1 Participation Rates of Respondents Virtual Reality Vs. Non-VR Sections}

\begin{tabular}{lllll}
\hline & $\begin{array}{l}\text { Pre-Test } \\
\text { Responses }\end{array}$ & $\begin{array}{l}\text { Proportion of } \\
\text { Survey Sample (\%) }\end{array}$ & $\begin{array}{l}\text { Post-Test } \\
\text { Response }\end{array}$ & $\begin{array}{l}\text { Proportion of Survey } \\
\text { Sample (\%) }\end{array}$ \\
\hline Virtual Reality Sections & 87 & 67 & 75 & 69 \\
Non-VR Sections & 43 & 33 & 34 & 31 \\
$\mathrm{~N}$ & 130 & & 109 & \\
\hline
\end{tabular}

As mentioned, an introduction to international relations course was used for all sections, either VR or non-VR in order to increase the continuity of the sample. The course catalog defines this class as being focused on: "[t]heories and concepts in international politics and their application to contemporary world politics." Instructors for these sections allowed class time to discuss participate recruitment with the student and for a discussion of the research cover letter and basis for the research. Students then had the opportunity to complete the survey using the web-based learning system "eCampus". Students in these sections did not receive extra credit for taking the survey, nor did their participation in the survey impact their standing in the class. 
Students enrolled in the course incorporating the virtual reality goggles were required to purchase an inexpensive cardboard viewer (the only requirement other than purchasing a textbook). Throughout the course of the semester approximately fifteen short virtual reality videos were shown to students that corresponded to the lecture and readings.

Table 4.1 highlights that a larger proportion of the sample population were in the virtual reality class, as $67 \%$ of the pre-test and $69 \%$ of the post-test responses were from students in the class in which virtual reality was used. This is probably in direct relation to the course instructor who was a co-author of the study. In the virtual reality class, students were given time to complete the survey in class if they wished. Students in the non-VR sections were not given class time to complete the survey and the instructor asked them to complete the survey on their own time. Participants in each pre and post test iteration complete the following questions. 
Table 5.2 Sample Characteristics

\begin{tabular}{|c|c|c|}
\hline & Beginning of the Semester Survey & End of Semester Survey \\
\hline$\overline{\mathrm{N}}$ & 130 & 109 \\
\hline \multicolumn{3}{|l|}{ Gender } \\
\hline Male & $51 \%$ & $48 \%$ \\
\hline Female & $49 \%$ & $52 \%$ \\
\hline Age & Mean: 19.25 & Mean 19.50 \\
\hline \multicolumn{3}{|l|}{ Race } \\
\hline White & $95 \%$ & $94 \%$ \\
\hline Black or African-Americans & $4 \%$ & $5 \%$ \\
\hline American Indian or Alaska Native & - & - \\
\hline Asian & $1 \%$ & $1 \%$ \\
\hline $\begin{array}{l}\text { Native Hawaiian or other Pacific } \\
\text { Islander }\end{array}$ & - & - \\
\hline \multicolumn{3}{|l|}{ Hispanic } \\
\hline No & $98 \%$ & $100 \%$ \\
\hline Yes & $2 \%$ & - \\
\hline \multicolumn{3}{|l|}{ State of Residence } \\
\hline West Virginia & $55 \%$ & $60 \%$ \\
\hline Other States/Territories & $40 \%$ & $35 \%$ \\
\hline International & $5 \%$ & $5 \%$ \\
\hline \multicolumn{3}{|l|}{ Social Class } \\
\hline Lower Class & $10 \%$ & $9 \%$ \\
\hline Working Class & $15 \%$ & $17 \%$ \\
\hline Lower Middle Class & $42 \%$ & $45 \%$ \\
\hline Upper Middle Class & $25 \%$ & $23 \%$ \\
\hline Upper Class & $8 \%$ & $6 \%$ \\
\hline \multicolumn{3}{|l|}{ Credit Hours } \\
\hline $0-28$ hours & $30 \%$ & $28 \%$ \\
\hline $29-58$ hours & $35 \%$ & $31 \%$ \\
\hline 59-88 hours & $20 \%$ & $25 \%$ \\
\hline $89+$ hours & $15 \%$ & $16 \%$ \\
\hline \multicolumn{3}{|l|}{ GPA } \\
\hline 1.9 and below & $12 \%$ & $9 \%$ \\
\hline $2.0-2.49$ & $15 \%$ & $20 \%$ \\
\hline $2.5-2.99$ & $22 \%$ & $21 \%$ \\
\hline $3.0-3.49$ & $34 \%$ & $39 \%$ \\
\hline $3.5-4.0$ & $17 \%$ & $11 \%$ \\
\hline \multicolumn{3}{|l|}{ Major } \\
\hline Political Science & $52 \%$ & $51 \%$ \\
\hline International Studies & $42 \%$ & $40 \%$ \\
\hline Other & $6 \%$ & $9 \%$ \\
\hline
\end{tabular}

\section{Control Variables}

In the same fashion as Chapters Three and Four, this chapter uses the same control variables when assessing changes in social capital, bridging and bonding social capital, and the addition of an empathy variable. For this chapter, all of the following control variables were 
constructed using the same questions as in Chapter Three, unless noted: Gender, Age, Race, State of Residence, Social Class, Credit Hours, and GPA. These were coded using the same procedure as in Chapter Three, so that chapter should be referenced to understand variable construction. Academic major control was slightly reworked using the following method:

Academic Major - Participants were asked to indicated major program; however, with over 125 applicable majors, it was necessary to recode this variable into the categories with the most frequency. Students could choose: "Political Science" coded "1," "International Studies", coded "2" and "Other" coded "3." This is a slight variation from the previous two chapters since each focused-on service-learning courses with students predominately in multidisciplinary studies and political science.

Number of Videos - Respondents who indicated they were in the VR setting were asked in the post-test "Approximately how many of the videos did you watch using virtual reality goggles?" They could respond "All or most of the assigned videos" (coded 1); "Over half of the assigned videos" (2); "Less than half of the assigned videos" (3); "Only several of the assigned videos" (4); "I did not watch any of the videos" (5). There responses were recoded in reverse order starting at "0" and going to " $4 . "$

Additionally, the previous experiential education controls were not used in this chapter.

\section{$\underline{\text { Social Capital Variables }}$}

Again, the construction of these variables is identical to those in Chapter Three.

Questions from ANES 2016 and the 2000 and 2006 Social Capital Community Survey were used to construct each of the following variables. Social capital is gauged using political participation, civic participation, religious participation, informal social connections, and trust. Chapter Three should be referenced in order to understand how the variables were created and coded. 


\begin{tabular}{|c|c|c|c|c|c|c|}
\hline & $\begin{array}{l}\text { Pre-Test VR } \\
\text { Section }\end{array}$ & $\begin{array}{l}\text { Post-Test VR } \\
\text { Section }\end{array}$ & $\begin{array}{l}\text { Mean } \\
\text { Difference }\end{array}$ & $\begin{array}{l}\text { Pre-Test } \\
\text { Non-VR } \\
\text { Section }\end{array}$ & $\begin{array}{l}\text { Post-Test Non- } \\
\text { VR Section }\end{array}$ & $\begin{array}{l}\text { Mean } \\
\text { Difference }\end{array}$ \\
\hline $\begin{array}{l}\text { Political } \\
\text { Participation }\end{array}$ & $\begin{array}{l}.65 \\
(.33)\end{array}$ & $\begin{array}{l}.70 \\
(.43)\end{array}$ & $\begin{array}{l}.05 \\
(.06)\end{array}$ & $\begin{array}{l}.69 \\
(.91)\end{array}$ & $\begin{array}{l}.70 \\
(.75)\end{array}$ & $\begin{array}{l}.01 \\
(.19)\end{array}$ \\
\hline $\begin{array}{l}\text { Civic } \\
\text { Participation }\end{array}$ & $\begin{array}{l}.52 \\
(.74)\end{array}$ & $\begin{array}{l}.55 \\
(.10)\end{array}$ & $\begin{array}{l}.03 \\
(.09)\end{array}$ & $\begin{array}{l}.61 \\
(.99)\end{array}$ & $\begin{array}{l}.70 \\
(.70)\end{array}$ & $\begin{array}{l}.09 \\
(.20)\end{array}$ \\
\hline $\begin{array}{l}\text { Religious } \\
\text { Participation }\end{array}$ & $\begin{array}{l}2.01 \\
(2.66)\end{array}$ & $\begin{array}{l}1.99 \\
(1.22)\end{array}$ & $\begin{array}{l}-.02 \\
(.33)\end{array}$ & $\begin{array}{l}1.99 \\
(.90)\end{array}$ & $\begin{array}{l}2.09 \\
(3.01)\end{array}$ & $\begin{array}{l}.10 \\
(.48)\end{array}$ \\
\hline $\begin{array}{l}\text { Informal Social } \\
\text { Connections }\end{array}$ & $\begin{array}{l}3.33 \\
(1.01)\end{array}$ & $\begin{array}{l}3.33 \\
(1.78)\end{array}$ & $\begin{array}{l}.00 \\
(.22)\end{array}$ & $\begin{array}{l}2.89 \\
(2.00)\end{array}$ & $\begin{array}{l}3.10 \\
(1.87)\end{array}$ & $\begin{array}{l}.21 \\
(.45)\end{array}$ \\
\hline \multicolumn{7}{|l|}{ Trust } \\
\hline Institutional & $\begin{array}{l}2.19 \\
(.99)\end{array}$ & $\begin{array}{l}2.33 \\
(.70)\end{array}$ & $\begin{array}{l}.14 \\
(.14)\end{array}$ & $\begin{array}{l}1.99 \\
(2.99)\end{array}$ & $\begin{array}{l}2.15 \\
(2.15)\end{array}$ & $\begin{array}{l}.16 \\
(.61)\end{array}$ \\
\hline Individual & $\begin{array}{l}3.10 \\
(2.55)\end{array}$ & $\begin{array}{l}3.19 \\
(2.00)\end{array}$ & $\begin{array}{l}.09 \\
(.36)\end{array}$ & $\begin{array}{l}3.00 \\
(1.54)\end{array}$ & $\begin{array}{l}3.55 \\
(1.79)\end{array}$ & $\begin{array}{l}.55 \\
(.38)\end{array}$ \\
\hline $\mathrm{N}$ & 87 & 75 & & 43 & 34 & \\
\hline
\end{tabular}

Note. Standard errors are reported in parenthesis. A two-tailed T-test was run on the difference of means and is provided in the mean difference column. Two-tailed significance tests: ${ }^{*} p<.10,{ }^{* *} p<.05,{ }^{* * *} p<.01$.

Table 5.3 suggests an interesting relationship between VR and traditional measures of social capital; specifically, there appears to be no significant difference in means between pre and posttest analysis. What this suggests is that the experiential education, discussed in Chapters Three and Four, does develop some measures of social capital, but the use of an innovative teaching tool, like VR, does not have the same impact. As Table 5.3 illustrates, the fact that neither the VR nor non-VR section appears to have an increase or decrease in means that is statistically significant. This will be addressed more completely in the conclusion, but this suggests that educators need to employ multiple teaching techniques in order to obtain certain outcomes. As a result of this data, it is possible that hypothesis 1 needs to be rejected. 


\section{Bridging and Bonding Social Capital Variables}

Williams (2006) and Ellison et al. (2014) rationale for construction of these variables is again used. The questions asked and how the responses were coded follows the same logic at Chapter Three. Therefore, that chapter should be referenced in regard to variable construction.

Table 5.4 Bridging and Bonding Social Capital Means Comparison for Virtual Reality Vs. Non-Virtual Reality Course Sections

\begin{tabular}{lllllll}
\hline & $\begin{array}{l}\text { Pre-Test VR } \\
\text { Section }\end{array}$ & $\begin{array}{l}\text { Post-Test VR } \\
\text { Section }\end{array}$ & $\begin{array}{l}\text { Mean } \\
\text { Difference }\end{array}$ & $\begin{array}{l}\text { Pre-Test } \\
\text { Non-VR } \\
\text { Section }\end{array}$ & $\begin{array}{l}\text { Post-Test Non- } \\
\text { VR Section }\end{array}$ & $\begin{array}{l}\text { Mean } \\
\text { Difference }\end{array}$ \\
\hline Bridging Social & 3.99 & 4.26 & $.27^{*}$ & 3.45 & 3.55 & .10 \\
Capital & $(.99)$ & $(1.07)$ & $(.16)$ & $(1.22)$ & $(1.99)$ & $(.37)$ \\
Bonding Social & 2.88 & 3.55 & $.67^{* * *}$ & 3.10 & 3.25 & .15 \\
Capital & $(.56)$ & $(.99)$ & $(.12)$ & $(1.88)$ & $(.99)$ & $(.68)$ \\
$\mathrm{N}$ & 87 & 75 & & 43 & 34 & \\
\hline
\end{tabular}

Note. Standard errors are reported in parenthesis. A two-tailed T-test was run on the difference of means and is provided in the mean difference column. Two-tailed significance tests: ${ }^{*} \mathrm{p}<.10,{ }^{* *} \mathrm{p}<.05,{ }^{* * *} \mathrm{p}<.01$.

Whereas, the results in the previous chapters did not show significance in bridging or bonding scores, the mean difference for the students in the VR section did show a positive impact on scores that was statistically significant. Table 5.4 indicates that the means for students in the VR section did increase in both bridging and bonding, while there the positive increase in the non-VR students was not statistically significant. This supports hypothesis 2 and suggests that a further analysis needs to occur.

\section{Empathy Variable}

In 2010, Konrath and her fellow researchers at the University of Michigan determined "[c]ollege kids today are about 40 percent lower in empathy than their counterparts of 20 or 30 years ago, as measured by standard tests of this personality trait" (Swanbrow 2010). Konrath et al. (2011) goes on to suggest that empathy may be declining for a variety of reasons, but that it is not the case that something can be done about that decline. Importantly, the authors conclude 
that empathy is teachable in children and young adults. Therefore, it stands to reason that virtual reality may be one of the experiential ways to provide the necessary tools of "teaching" empathy.

The World Economic Forum (WEF) has been examining ways in which empathy is developed and why we need to care about its development (Molenberghs 2017). It is argued that empathy can be taught, or at least developed, in order to make individuals better connect to people not in their groups. It is also argued that social capital is in decline in America (Putnam 2000). However, with an increase in online technology it is possible that social capital may manifest itself in different ways than Putnam measured 17 years ago (Ellison et al. 2014; Williams 2006). Therefore, it is necessary to see if individuals develop the bridging and bonding social capital that Putnam describes in other ways. Using empathy measures developed by Reniers et al., I measured how empathy is affected through the use of virtual reality goggles in a classroom setting. Also, I used the measures of Williams and Ellison et al. to ascertain the effect of virtual reality on the development of bridging and bonding social capital through a pre-test and post-test survey.

In the World Economic Forum pieces dealing with empathy, Pascal Molenberghs, a senior lecturer in social neuroscience, discusses the differences between affective and cognitive empathy. He finds that affective empathy "is the ability to share the emotions of others" and cognitive empathy "is the ability to understand the emotions of others" (2017). These types of empathy are solidified by research of Reniers et al. (2011) and their work developing a questionnaire of cognitive and affective empathy (QCAE).

Based upon the QCAE, it is possible to discern if cognitive and affective empathy are developed as a result of an introduced stimuli. In the case of this research, the stimuli is the virtual reality goggles and the videos watched on them. Because of the research associated with 
the QCAE, the following 31 questions they have tested and verified to accurately indicate the

level of empathy a respondent has.

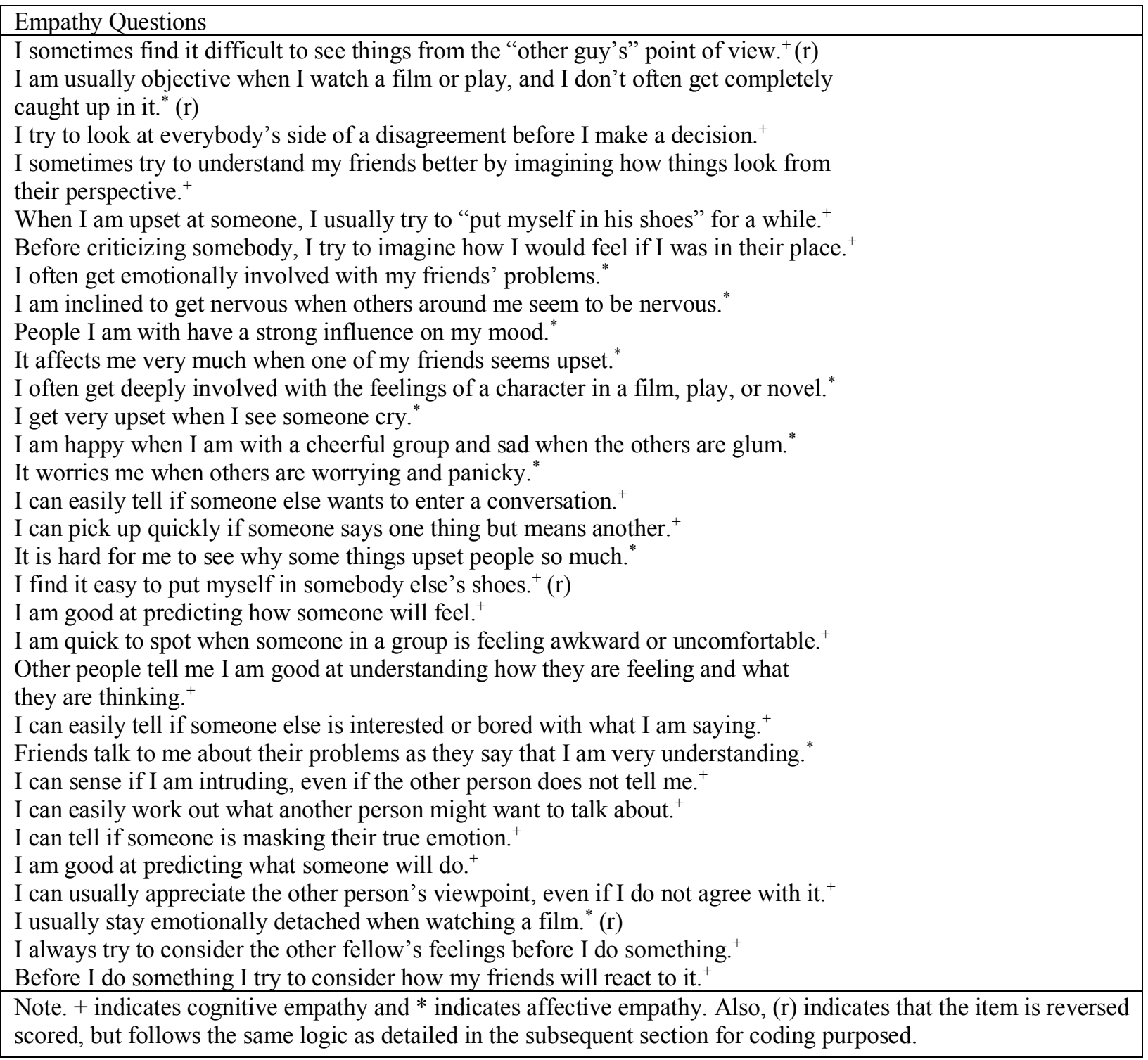

Participants in each survey were asked how much they agreed with each statement based on a 4-point Likert scale ranging from strongly agree (coded 1); slightly agree (2); slightly disagree (3); strongly disagree (4). These were recoded in reverse order as such: strongly agree (coded 4); slightly agree (3); slightly disagree (2); strongly disagree (1). It can be noted that a 
fifth option "neither agree nor disagree" is not present because the QCAE does not include this under the premise that it makes a respondent essentially take a position on the statement.

Table 5.5 Affective and Cognitive Empathy Means Comparison for Virtual Reality Vs. Non-Virtual Reality Course Sections

\begin{tabular}{lllllll}
\hline & $\begin{array}{l}\text { Pre-Test VR } \\
\text { Section }\end{array}$ & $\begin{array}{l}\text { Post-Test VR } \\
\text { Section }\end{array}$ & $\begin{array}{l}\text { Mean } \\
\text { Difference }\end{array}$ & $\begin{array}{l}\text { Pre-Test } \\
\text { Non-VR } \\
\text { Section }\end{array}$ & $\begin{array}{l}\text { Post-Test Non- } \\
\text { VR Section }\end{array}$ & $\begin{array}{l}\text { Mean } \\
\text { Difference }\end{array}$ \\
\hline Affective & 2.10 & 2.99 & $.89^{* * *}$ & 2.22 & 2.31 & .09 \\
Empathy & $(.44)$ & $(.75)$ & $(.10)$ & $(.55)$ & $(.90)$ & $(.17)$ \\
Cognitive & 2.55 & 3.10 & $.10^{* * *}$ & 2.54 & 2.99 & .45 \\
Empathy & $(.90)$ & $(1.02)$ & $(.15)$ & $(1.76)$ & $(1.01)$ & $(.34)$ \\
$\mathrm{N}$ & 87 & 75 & & 43 & 34 & \\
\hline
\end{tabular}

Note. Standard errors are reported in parenthesis. A two-tailed T-test was run on the difference of means and is provided in the mean difference column. Two-tailed significance tests: ${ }^{*} \mathrm{p}<.10,{ }^{* *} \mathrm{p}<.05,{ }^{* * *} \mathrm{p}<.01$.

Table 5.5 highlights an increase in both affective and cognitive empathy in students in the VR section, while there is no statistical weight to the increase in the non-VR class. This continues to build the case that various teaching strategies and techniques may need to be employed to gain desired outcomes. Whereas, experiential education seems to increase some measures of social capital, the use of VR seems to increase bridging and bonding social capital and both types of empathy. What this means is that hypothesis 3 also has some support, and that educators should think about using multiple methods to increase a student's proclivity to become an engaged citizen.

\section{Qualitative Variable Construction and Explanation}

Using the same methodology discussed in Chapter Three, Figures 5.1 through 5.6 were created. The same questions were asked as in this chapter. The same procedure detailed in Chapter Three were used to construct the clouds in regard to process and omitted words and phrases. 
$\underline{\text { Results }}$

\section{Quantitative Findings}

To produce the results in Tables 5.6 - 5.8 OLS regression was run and the data presented displays the results for students in the VR sections versus the non-VR sections from the beginning of the semester pretest to the end of the semester posttest. The following results support the some of the initial thoughts drawn by the difference of means tests in the previous sections. 
Table 5.6 Effect of VR in Classroom on Social Capital

\begin{tabular}{|c|c|c|}
\hline & Virtual Reality & Non-Virtual Reality \\
\hline Political Participation & $\begin{array}{l}0.03 \\
(0.09)\end{array}$ & $\begin{array}{l}0.02 \\
(0.25)\end{array}$ \\
\hline Civic Participation & $\begin{array}{l}0.01 \\
(0.05)\end{array}$ & $\begin{array}{l}0.03 \\
(0.33)\end{array}$ \\
\hline Religious Participation & $\begin{array}{l}0.29 \\
(0.55)\end{array}$ & $\begin{array}{l}-0.15 \\
(0.37)\end{array}$ \\
\hline Informal Social & -0.22 & 0.20 \\
\hline $\begin{array}{l}\text { Connections } \\
\text { Trust }\end{array}$ & $(0.15)$ & $(0.33)$ \\
\hline Institutional & $\begin{array}{l}0.42 \\
(0.44)\end{array}$ & $\begin{array}{l}0.21 \\
(0.15)\end{array}$ \\
\hline Individual & $\begin{array}{l}0.35 \\
(0.29)\end{array}$ & $\begin{array}{l}0.41 \\
(0.55)\end{array}$ \\
\hline Gender & $\begin{array}{l}0.11 \\
(0.07)\end{array}$ & $\begin{array}{l}0.02 \\
(0.01)\end{array}$ \\
\hline Age & $\begin{array}{l}0.01 \\
(0.01)\end{array}$ & $\begin{array}{l}0.09 \\
(0.10)\end{array}$ \\
\hline Race & $\begin{array}{l}0.14 \\
(0.17)\end{array}$ & $\begin{array}{l}0.23 \\
(0.09)\end{array}$ \\
\hline Hispanic & $\begin{array}{l}0.00 \\
(0.05)\end{array}$ & $\begin{array}{l}0.00 \\
(0.10)\end{array}$ \\
\hline State of Residence & $\begin{array}{l}0.55^{*} \\
(.03)\end{array}$ & $\begin{array}{l}0.09 * \\
(.03)\end{array}$ \\
\hline Social Class & $\begin{array}{l}0.25^{*} \\
(0.05)\end{array}$ & $\begin{array}{l}0.22 \\
(0.15)\end{array}$ \\
\hline Credit Hours & $\begin{array}{l}0.21 \\
(0.12)\end{array}$ & $\begin{array}{l}0.29 \\
(0.14)\end{array}$ \\
\hline GPA & $\begin{array}{l}0.31 \\
(0.12)\end{array}$ & $\begin{array}{l}0.55 \\
(0.11)\end{array}$ \\
\hline Major & $\begin{array}{l}-0.44 \\
(0.57)\end{array}$ & $\begin{array}{l}-0.54 \\
(0.45)\end{array}$ \\
\hline Videos Viewed & $\begin{array}{l}.98^{*} \\
(.33)\end{array}$ & - \\
\hline Constant & $\begin{array}{l}0.00 \\
(0.11)\end{array}$ & $\begin{array}{l}0.00 \\
(0.22)\end{array}$ \\
\hline $\mathrm{R}^{2}$ & 0.09 & 0.04 \\
\hline
\end{tabular}

Note. Coefficients estimated using OLS and robust standard errors in parentheses. Two-tailed significance tests: ${ }^{*} \mathrm{p}$ $<.10, * * \mathrm{p}<.05, * * * \mathrm{p}<.01$.

While Table 5.6 does suggest some statistical significance in control variables, the typical measures of social capital exhibit no statistical significance in this OLS modeling. This means that hypothesis 1 can be rejected. It does cause an interesting question to be raised about the use of various teaching techniques within the classroom. If experiential education could create both political and civic participation in students, one would initially surmise that VR could do the 
same. However, it is possible that there needs to be a multitude of techniques used by educators to fully address citizen development. Much like Hunter and Brisbin surmised that experiential education is not a catchall, it is necessary to surmise that not all teaching tools are effective at the same outcomes.

Table 5.7 Effect of VR on Bridging and Bonding Social Capital

\begin{tabular}{|c|c|c|}
\hline & Virtual Reality & Non-Virtual Reality \\
\hline Bridging Social Capital & $\begin{array}{l}0.33 * * \\
(0.04)\end{array}$ & $\begin{array}{l}0.10 \\
(0.22)\end{array}$ \\
\hline Bonding Social Capital & $\begin{array}{l}0.22 * * \\
(0.05)\end{array}$ & $\begin{array}{l}0.31 \\
(0.45)\end{array}$ \\
\hline Gender & $\begin{array}{l}0.11 \\
(0.10)\end{array}$ & $\begin{array}{l}-0.12 \\
(0.17)\end{array}$ \\
\hline Age & $\begin{array}{l}0.22 \\
(0.12)\end{array}$ & $\begin{array}{l}0.45 \\
(0.71)\end{array}$ \\
\hline Race & $\begin{array}{l}0.00 \\
(0.05)\end{array}$ & $\begin{array}{l}0.01 \\
(0.09)\end{array}$ \\
\hline Hispanic & $\begin{array}{l}0.01 \\
(0.06)\end{array}$ & $\begin{array}{l}0.00 \\
(0.02)\end{array}$ \\
\hline State of Residence & $\begin{array}{l}0.33^{*} \\
(.06)\end{array}$ & $\begin{array}{l}0.23 \\
(.58)\end{array}$ \\
\hline Social Class & $\begin{array}{l}0.44^{*} \\
(0.09)\end{array}$ & $\begin{array}{l}0.21 \\
(0.19)\end{array}$ \\
\hline Credit Hours & $\begin{array}{l}0.21 \\
(0.29)\end{array}$ & $\begin{array}{l}-0.17^{*} \\
(0.04)\end{array}$ \\
\hline GPA & $\begin{array}{l}0.03 \\
(0.56)\end{array}$ & $\begin{array}{l}0.02 \\
(0.09)\end{array}$ \\
\hline Major & $\begin{array}{l}0.33^{*} \\
(0.10)\end{array}$ & $\begin{array}{l}0.31^{*} \\
(0.09)\end{array}$ \\
\hline Videos Viewed & $\begin{array}{l}0.11 \\
(.10)\end{array}$ & - \\
\hline Constant & $\begin{array}{l}0.00 \\
(0.03)\end{array}$ & $\begin{array}{l}0.00 \\
(0.09)\end{array}$ \\
\hline $\begin{array}{l}\mathrm{R}^{2} \\
\mathrm{~N}\end{array}$ & $\begin{array}{l}0.21 \\
162\end{array}$ & $\begin{array}{l}0.03 \\
77\end{array}$ \\
\hline $\begin{array}{l}\text { Note. Coefficients estim } \\
<.10, * * \mathrm{p}<.05, * * * \mathrm{p}<\end{array}$ & using OLS and $\mathrm{r}$ & theses. Two-tailed significance tests: ${ }^{*} p$ \\
\hline
\end{tabular}


possible to help students understand the plight of those that are different than them, and care about their situations. Table 5.7 also underscores that hypothesis 2 must be accepted.

Table 5.8 Effect of VR on Affective and Cognitive Empathy

\begin{tabular}{|c|c|c|}
\hline & Virtual Reality & Non-Virtual Reality \\
\hline Affective & $\begin{array}{l}0.44^{* * *} \\
(0.09)\end{array}$ & $\begin{array}{l}0.10 \\
(0.27)\end{array}$ \\
\hline Cognitive & $\begin{array}{l}0.35^{* * *} \\
(0.03)\end{array}$ & $\begin{array}{l}0.12 \\
(0.31)\end{array}$ \\
\hline Gender & $\begin{array}{l}0.09 \\
(0.22)\end{array}$ & $\begin{array}{l}0.17 \\
(0.09)\end{array}$ \\
\hline Age & $\begin{array}{l}0.04 \\
(0.10)\end{array}$ & $\begin{array}{l}0.09 \\
(0.18)\end{array}$ \\
\hline Race & $\begin{array}{l}0.09 \\
(0.22)\end{array}$ & $\begin{array}{l}0.11 \\
(0.09)\end{array}$ \\
\hline Hispanic & $\begin{array}{l}0.01 \\
(0.01)\end{array}$ & $\begin{array}{l}0.09 \\
(0.09)\end{array}$ \\
\hline State of Residence & $\begin{array}{l}-.22 * * \\
(.01)\end{array}$ & $\begin{array}{l}-0.09^{*} \\
(.01)\end{array}$ \\
\hline Social Class & $\begin{array}{l}0.28^{*} \\
(0.02)\end{array}$ & $\begin{array}{l}-0.12^{*} \\
(0.03)\end{array}$ \\
\hline Credit Hours & $\begin{array}{l}0.10 \\
(0.33)\end{array}$ & $\begin{array}{l}0.16 \\
(0.24)\end{array}$ \\
\hline GPA & $\begin{array}{l}0.37^{*} \\
(0.09)\end{array}$ & $\begin{array}{l}0.03 \\
(0.15)\end{array}$ \\
\hline Major & $\begin{array}{l}0.55^{*} \\
(0.13)\end{array}$ & $\begin{array}{l}0.22 * \\
(0.03)\end{array}$ \\
\hline Videos Viewed & $\begin{array}{l}.88^{*} \\
(0.11)\end{array}$ & - \\
\hline Constant & $\begin{array}{l}0.00 \\
(0.04)\end{array}$ & $\begin{array}{l}0.00 \\
(0.10)\end{array}$ \\
\hline $\begin{array}{l}\mathrm{R}^{2} \\
\mathrm{~N}\end{array}$ & $\begin{array}{l}0.19 \\
162\end{array}$ & $\begin{array}{l}0.13 \\
77\end{array}$ \\
\hline
\end{tabular}

Table 5.8 illustrates that both affective and cognitive empathy are developed as a result of the inclusion of VR in the sections of "Introduction to International Relations" at a statistically significant rate. Recalling Reniers et al. (2011) work, affective empathy suggests that students are more willing to share their emotions. This could be in relation to discussing the videos in class and asking students to confront the harsh realities that are often viewed in the VR videos. Additionally, cognitive empathy could be increasing because students are gaining knowledge about the situations of the "other." Both of these should be taken into consideration when 
thinking about bridging and bonding social capital. You would expect all of these to increase if students are truly gaining from the VR experience. The results presented in Table 5.8 also mean that hypothesis 3 should be accepted.

\section{Qualitative Findings}

As discussed in the construction of the survey, it was imperative to obtain student responses to the videos they were instructed to watch using virtual reality. The responses below, shown in word clouds, signify why that was so important. The responses illustrate that the students using virtual reality had positive experiences. Those experiences are key to the use of innovative teaching techniques. As suggested in the subsequent conclusion, these responses enable the results presented in the quantitative section to be even more relevant. As bridging and bonding social capital and empathy develop, students develop additional means of understanding the context and relevancy of those VR videos. Much like the United Nations is trying to engage diplomats with the "other" these students clearly are developing means to process and understand complex international situations that impact millions around the world. 
Figure 5.1: Word cloud from "What was the best part of the virtual reality experience? ${ }^{10}$

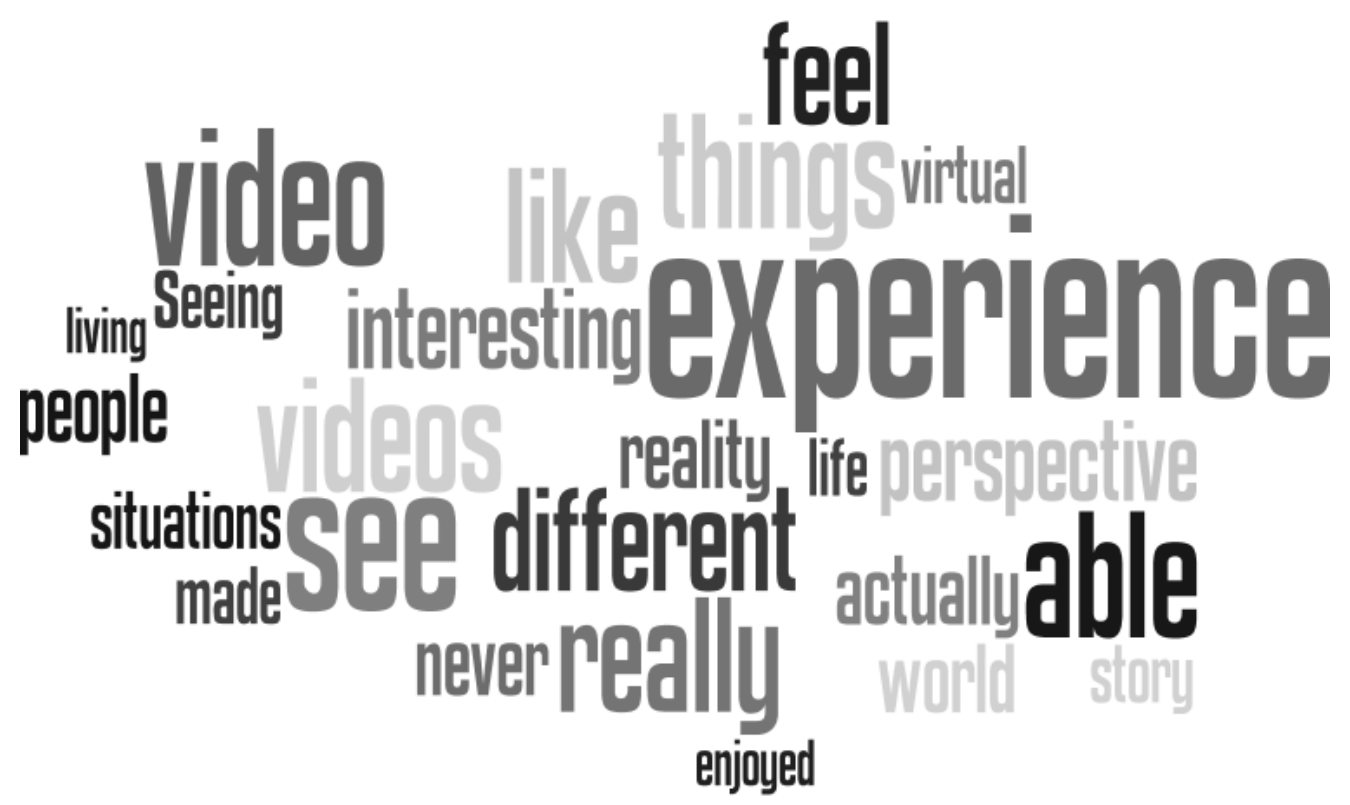

Created with software downloaded from wordle.net. Limited to 25 key words. The words "best" and "part" were omitted from this word cloud.

The qualitative responses have produced many profound findings that are important to understanding student learning and development as a citizen, and supplement the quantitative results presented previously. When asked to detail the "best part" students indicated that the "experience" gleamed from these videos was the highlight. One may be quick to surmise that experience was only included because it is part of the question and that it should be removed as the phrase "best part" was. But, an analysis of the responses that used the word "experience" note some interesting ideas encourage the inclusion of "experience" in this cloud. One student wrote that the best part was "getting to experience life in other countries." While another found the best part to be the real-world understanding it provide. The student wrote:

10 These "word clouds" were produced using the responses to the open-ended questions on questionnaire provided to students at the end of the semester. All of the clouds were constructed using the same methodology. That is, words that students used to answer the question in which they repeated a portion of the prompt question were deleted. The clouds show the 25 most common words used in response to each of these questions. 
I really enjoyed the virtual reality videos we were assigned. I loved being able to "experience" the different things we were learning about. It was defiantly more gripping and "oh wow, this is real" than just reading the book or articles.

These responses are but a few that detail how they liked the experience or that they were able to experience different things than you could typically do in the class. While the results on social capital and empathy were not what was hoped for, it is possible to see that this form of learning is having an applicability to student learning that cannot be denied.

Figure 5.2: Word cloud from "What did you learn by watching the virtual reality videos?

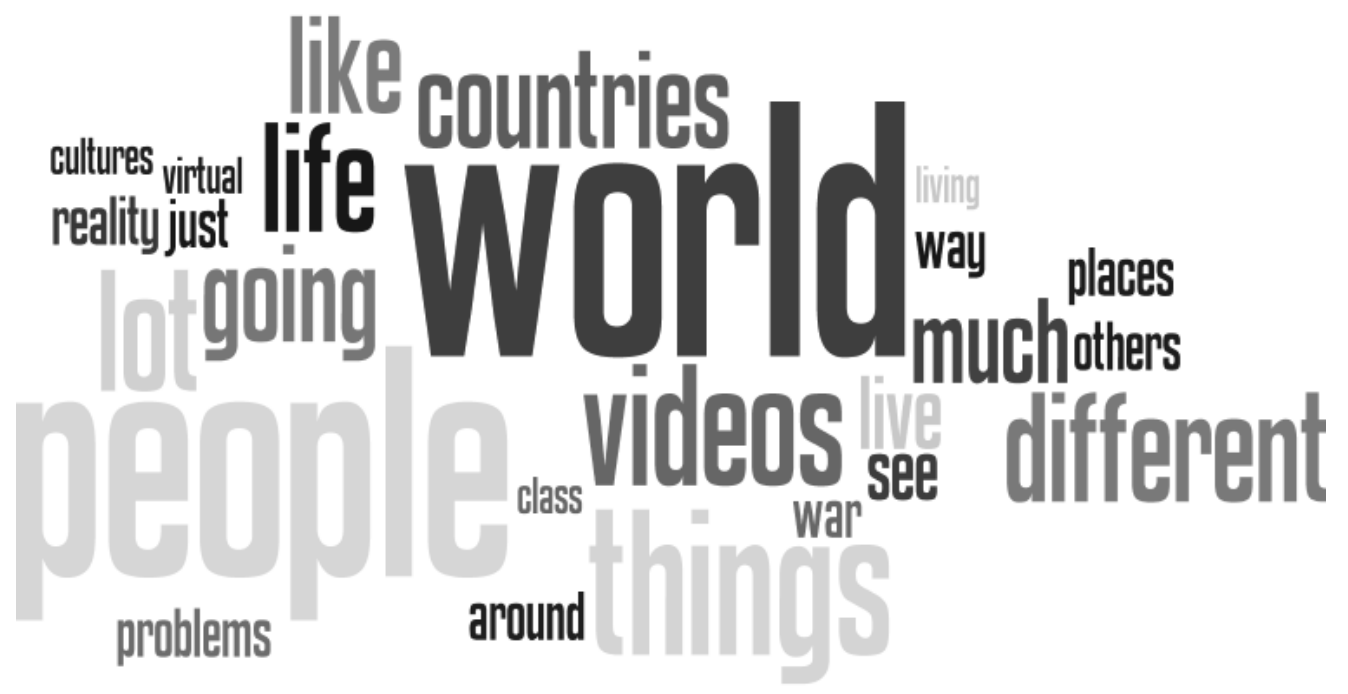

Created with software downloaded from wordle.net. Limited to 25 key words. The word "learned" was omitted from this word cloud.

Figure 5.2 highlights something important that bolsters the results of the quantitative data; specifically an overwhelming number of students viewing the VR experiences noted that they learned about the "world" and "people" in that world. As a political science educator, the responses to this question were particularly meaningful as we grapple with ways to engage students with course material and to care about issues on a local, national, and global scale. The responses to this portion of the survey should make faculty and institutions more likely to 
employ and support innovative teaching techniques as we try to develop citizens or even construct the idea of what a citizen is in the $21^{\text {st }}$ century.

To underscore the learning that students reported, there are several short responses included in regard to the question about what the participant learned. One student wrote, "What I learned from the videos, is that often times things you read or hear about in relation to crises overseas usually barely scratch the surface of what is really going on." Another suggested that: "Many people live in poverty, fear, or under a relentless government. Here in the U.S. we have grown so accustomed to a particular way of life that it is hard to imagine. Even the homeless members of our society are much better off than some others in LDC's."

These responses were typical for this question and do suggest that social capital and empathy are developing, in direct support of the data and hypothesis 2 and 3. Perhaps students are also developing the necessary skills to interpret events later in their lives that will lead to continued citizen development. If students are expected to form into the perfect citizen over the course of a semester, educators will surely be disappointed. However, if educators can give them the experiences to grow into citizens, the goal may be accomplished, though multiple methods need to be used in order to fully realize that reality. 
Figure 5.3: Word cloud from "What was the worst part of the virtual reality experience?

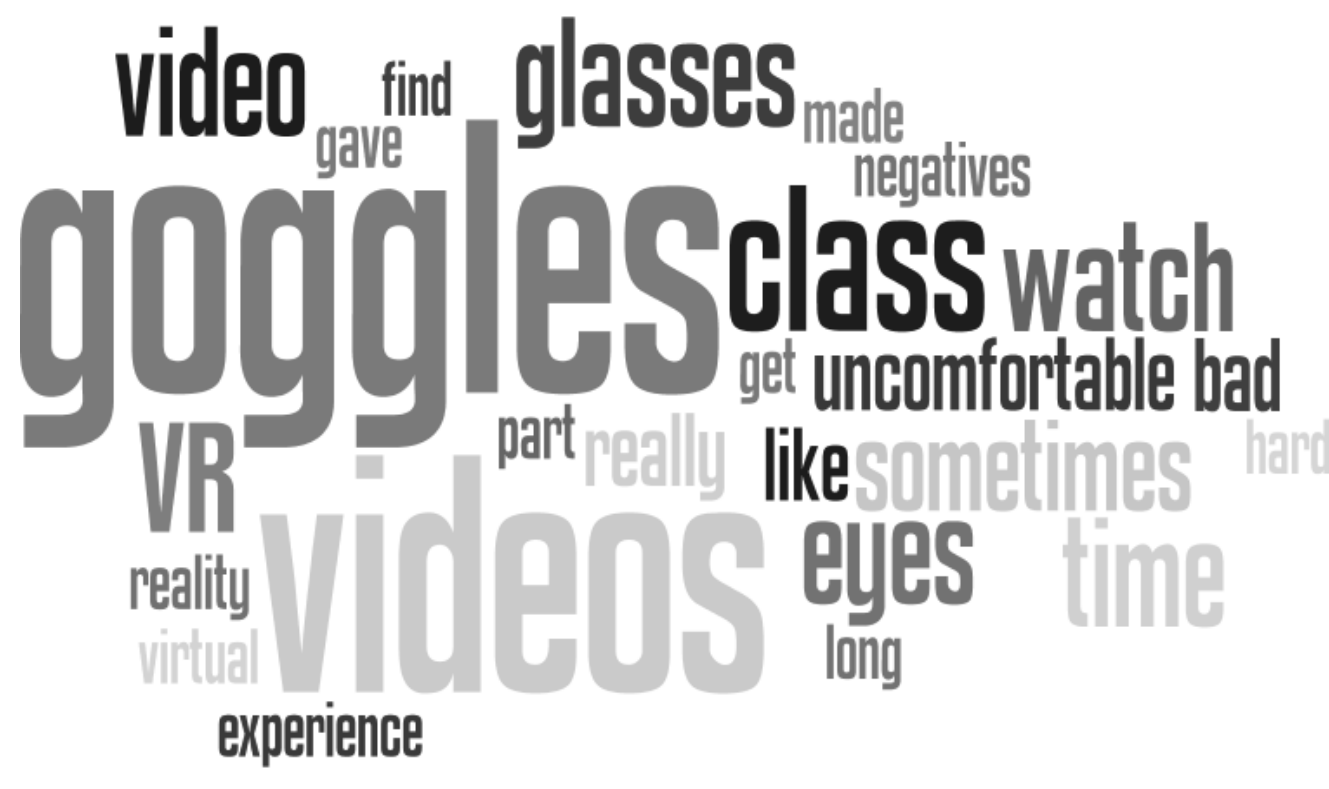

Created with software downloaded from wordle.net. Limited to 25 key words. The words "worst" and "part" were omitted from this word cloud.

Figure 5.3 does not necessarily address the development of student citizens, but it is important as educators attempt to develop pedagogy for using VR in the classroom. It is important to understand what goes right (i.e. development of bridging and bonding social capital and empathy), but to be an effective educator, it is also important to know what went wrong and why. Expectedly, the most negative portion of the VR experience wasn't necessarily the videos, but the googles used to view the videos. Students often complained about the how uncomfortable the goggles were, and this was often exacerbated if the student wore glasses to aid in their eyesight. Since the goggles were a necessity of the viewing experience to fully immerse the student in the action of the video, they did have to buy goggles. Still, students were able to buy any pair that they wanted to for class. Some opted to by a pair on clearance at Walmart for $\$ 3-5$, while others spent more money on a "fancier" pair they found on the internet for upwards of \$15-20. Even if all of the students were to have the same viewers, one can surmise that not 
everyone would be happy with that pair. Therefore, student preference on goggles should not necessarily be viewed as a limitation to the findings of this research. Instead, it does suggest that students may have approached the videos differently if they hadn't been uncomfortable. Still, the experience did seem to yield positive results as evidenced by Figures 5.1 and 5.2.

As noted, the response of "videos" did come up in the open-ended responses enough to be the second biggest word in the cloud. A further review of those responses suggest that students were not saying that the videos were the worst part, but that technological issues were a result of the responses. For instance, one student wrote, "[s]ometimes it took a long time for the videos to load." While another student wrote, "it would be the download time or streaming time behind each video." This does not suggest that there were major complaints with the videos, but that the technology used to deliver the experience was limited. Thus, this made the experience worse in the respondent's opinion.

As one student response noted:

I was more willing to watch videos when they were assigned for a particular class. When assigned in bulk for the rest of the semester, I was less likely to watch them until the very end before the test. - Student response to the "worst part" of the VR experience

The running times for each video, noted in Appendix D, illustrates that it may not be possible to watch every experience in its entirety in class. While most of the experiences were short, less than 5 minutes, there where the occasional 10- or 15-minute videos. Since the videos were selected to compliment class readings, lectures and class discussion, it is possible, and even likely that the videos were then given to students to view outside of the class meeting time. If students were left to watch the videos on their own time, it is possible that they did not watch the videos at all. One area for curriculum development may be in insuring that ample time is 
constructed into the class that allows for all of the videos to be watched as part of the class, during the regular scheduled meeting time.

Observing classes on days when the virtual reality was used highlighted other limitations to the practice and may have impacted results in this chapter. Technological issues were rampant with this type of learning. If students did not download the video before class, it was possible that the university-wide WIFI would not allow the videos to stream. Students often forgot their headphones or virtual reality viewing goggles. Though unsurprisingly, students never forgot to bring their cell phones to class. To address these issues, if it were possible for the instructor to keep the goggles and headphones and then distribute on the day of the in-class viewing, this would help to alleviate some of the problems.

As with any form of innovative teaching technique, there are many challenges that can only be addressed through trial and error. Now that some of those challenges have been identified, it may be possible to further integrate virtual reality into the classroom experience and yield entirely different results than those described in this chapter. For that reason, it is necessary to continue this research, further exploring the ideas presented within the research as a whole. Only by continuing to adapt to these challenges and limitations will it be possible to help students develop into citizens.

Additionally, it has been suggested by others who have reviewed this research that perhaps a short survey should have been conducted before and after each video. Obviously, for the sake of classroom time management this is not ideal. However, it does cause one to question if some videos are more or less successful at engaging students than others. While it was not the purpose of this research to determine the individual success of each VR experiences' impact on student learning, there may be future research that can help identify experiences that should be 
linked to specific lectures and discussions to elicit more thought and discussion from students on those issues.

\section{Conclusion}

The findings of this chapter illustrate the importance of innovative teaching techniques if student engagement in democracy is the goal. The positive link between VR and bridging and bonding social capital and empathy suggests that educators do have tools at their disposal to more fully engage students in the democratic process. The next chapter will address ways to link experiential education and other forms of innovative teaching techniques together in order to more completely address citizen development. However, it is clear from the research in this chapter that there are definitely means to achieving citizen development that go beyond what was highlighted in subsequent chapters.

Additionally, one of the main implications from the use of VR over two semesters is that students do enjoy and do respond to innovative teaching techniques. Most students showed some interest in understanding the world outside of their college community. While it is easy to contend that the statistical significance of this data would suggest otherwise, the student responses indicate that there is development going on within the students learning processes. When asked to indicate if they learned, students did not respond with harsh responses, even though they knew the results were anonymous. Instead, they provided insightful and wellreasoned rationales for how the videos enabled them to see a world(s) that they hadn't thought about or perhaps even cared to think about. Being able to provide students in a rural state the opportunity to "visit" these locations and understand the plight of others is important, especially with an ever-increasing isolationist view pushed by so many world leaders. As the world begins 
to close off, it is possible that VR can open new doors and opportunities for students to experience situations, events, and daily life that they may never have thought possible.

While students are clearly developing bridging and bonding social capital and empathy over the course of the semester, they may be also be developing the skills and tools necessary to build that social capital and empathy later in life. While there are some problems with asking respondents to answer the post-test so quickly after the intervention has occurred, it was necessary for this type of research. Still, it would be interesting to continue the research presented in this chapter to see if respondents remember those videos in 3,4 , or 5 years. If they do, and if they still have an impact of their perceptions of the world, it will be more likely that social capital and empathy was developing, we just weren't looking in the right places.

Research in this chapter attempted to ascertain the impact of the use virtual reality in the classroom on bridging and bonding social capital, as well as empathy. While the results should not suggest that virtual reality is a perfect substitute for first-hand experiences students gain through experiential learning, but provides a good foundation for understanding the "other", especially when it is difficult or even impossible to have first-hand experiences. The use of additional tools can only aid in citizen development, and educators must be willing to use all relevant means to engage their students. 


\section{Chapter Six: Continuing the Mission - Conclusions and Future Research}

Reflecting on the research presented in the previous chapters means understanding a way to progress forward, specifically for educators and institutions of higher education. It is important to note that the data presented does not suggest that experiential education or innovative teaching techniques will always yield the same, significant results. Instead, the findings of this research illustrate the importance of incorporating as many opportunities for student learning into the classroom as possible. It is important to understand that the traditional mode of learning may work in some instances, but if the goal is a more engaged citizenry, it is necessary to engage students with concepts and ideas that traditional lectures may not adequately address. Therefore, within this chapter limitations of the research presented will be addressed in order that future research can grow and be modified for better student results. Additionally, policy suggestions will be suggested that educators and institutions can implement in order to more fully engage a student citizenry with the democracy in which they act in.

At the end of this research it is apparent that some elements of social capital do increase as a result of experiential learning. Chapter Three supports the suggestion that exposure to service-learning and professional field experience causes students to have higher political and civic participation scores. Chapter Four build on this idea, and the data backs up the claim that those areas continue to see an increase even once a student graduates. While social capital as a whole may not increase, the elements that do are an important building block for an engaged citizenry. Without citizens who are willing to participate, politically and civically, it is difficult to understand how a democracy can continue to function.

Chapter Five further expands on the notion of including different teaching methods into the classroom in order to increase student participation in democracy. Specifically, the areas that 
did not see development in the other empirical chapters, virtual reality apparently has a direct impact on how students develop bridging and bonding social capital. Unsurprisingly, students also exhibit higher empathy scores when using VR, something that is related to the construct of the bridging and bonding variables.

\section{Obstacles and Limitations to Address}

Within the previous chapters there were clear limitations to the research that was presented. Some of the difficulties that come with studying experiential education's development of social capital in a higher education setting have already been addressed. Social capital has different definitions, which has created tension across disciplines employing this term. There are many difficult challenges that are addressed within this dissertation. Probably the most difficult to overcome is the fact that experiential education may be employed differently across institutions of higher education. Therefore, it may be difficult to produce results that are reproduceable at other institutions. Still, it is possible to see that there are opportunities for understanding how to connect with undergraduate students by using these different forms of experiential education. That connection can potentially help develop both social capital and empathy. Students who understand theory but have no connection to the outside world, may not have a strong sense of community. Therefore, this research is imperative for understanding how political science educators can learn to teach and help develop citizens.

One concern that needs to be addressed is that social capital may not be transferable from the location in which it was earned (Coleman 1988; La Due Lake and Huckfeldt 1998). If this is the case, how can the argument be made that developing social capital is important in a university setting when many students do not call the location of the institution their permanent home? While this is partially addressed by the findings in Chapter Four, one could potentially 
argue that those individuals developed social capital at the location of their institutions and had a higher proclivity for being engaged elsewhere. However, the social capital would be different than what was earned during one's undergraduate experience. It seems a little shortsighted to assume that social capital cannot be transferred, at least on some level. While it is to be expected that social networks and trust may diminish when an individual is no longer in that specific situation, it does not stand to reason that the individual will not make efforts to be engaged in the new community in which they find themselves. Therefore, it would be illogical to assume that merely by social capital's inability to be transferred, that any individual who had accrued capital in that specific instance would not be able to do the same in a new setting.

Another limitation when studying experiential education and social capital has not necessarily been well researched or documented. That is the failure of scholars outside of the experiential education world to completely accept the notion that service-learning, professional

field experience and empathy development are a valuable effort that should be researched and expanded throughout the country. Therefore, it is the goal of any future research to include means of addressing critics of this form of education.

\section{$\underline{\text { Policy Prescriptions }}$}

The third mission of the university is not less important than the first or second. Therefore, more resources, both monetary and research, need to be devoted to this form of learning in order to assess what experiential education can have on institutions, faculty, students, and the community. Those same concerns carry over to the use of any form of innovative teaching technique. If everyone is using the method differently, how can there be comparability between programs and methods?

In order to understand the any policy prescriptions, it is important to recall the 
experiential learning theory (ELT) discussed in Chapter 2. Remember, there are six common threads:

1. Learning is best conceived as a process, not in terms of outcomes. To improve learning in higher education, the primary focus should be on engaging students in a process that best enhances their learning. [...]

2. All learning is relearning. Learning is best facilitated by a process that draws out the students' beliefs and ideas about a topic so that they can be examined, tested, and integrated with new more refined ideas.

3. Learning requires the resolution of conflicts between dialectically opposed modes of adaption to the world. Conflict, differences, and disagreement are what drive the learning process. In the process of learning one is called upon to move back and forth between opposing modes of reflection and action and feeling and thinking.

4. Learning is a holistic process of adaptation to the world. Not just the result of cognition, learning involves the integrated functioning of the total person - thinking, feeling, perceiving, and behaving.

5. Learning results from synergetic transactions between the person and the environment. In Piaget's terms, learning occurs through equilibration of the dialectic processes of assimilating new experiences into existing concepts and accommodating existing concepts to new experience.

6. Learning is the process of creating knowledge. ELT proposes a constructivist theory of learning whereby social knowledge is created and recreated in the personal knowledge of the learner. (Kolb and Kolb 2005; 194)

To begin having meaningful policy prescriptions for educators and institutions, it is necessary to provide a way to move forward for each of these threads that is supported by the research in the previous chapters.

1. Learning enhancement - it cannot, and should not be the goal of the educator to always see results that are supported by empirical data. That is not to say that experiential education and innovative teaching techniques do not have data that supports the inclusion in the classroom. Instead, this means that educators need to be willing to learn and grow from mistakes. All too often, it is easy to rest on a tried and true method, but that is potentially leading to less engaged students. If citizen development is the goal of institutions and political science educators, failure must be an acceptable result. What works one semester may not work the next. 
Student demographics continue to shift, and it is imperative that educators be willing to adopt techniques that are not always successfully. However, the same educator must also be willing to ask why those practices are not working.

Tables 3.4, 3.5, 4.5, and 4.6 illustrate that the controls for previous exposure to experiential education is significant. This means that continually exposing students to this type of education is important for a richer, more developed experience for the student. If an educator, or institution, thinks that merely requiring one experiential education class will effectively address the third mission of the university, they are setting themselves up for disappointment. Instead, more classes across the university need to incorporate this type of learning in order to see this learning enhancement occur. While it could be beneficial for students to be exposed to even one course using experiential education or an innovative teaching technique, an effort needs to be made that seeks for broad departmental and institutional support for this type of teaching to increase student participation.

2. Learning is Relearning - what all forms of experiential education has in common is the need for students to get outside of their comfort zone and challenging their own ideas and beliefs. Much like educators need to constantly assess what works and does not work in the classroom, students should be challenged to support or refute their already preconceived ideas. This means that students are learning new information that is being processed to allow for growth. Specifically, within Chapter Five, it is clear that the use of VR seemed to help students learn more about the "other." Therefore, they were able to learn and grow from "interactions" with the VR videos that also led to higher bridging and bonding social capital.

Results in Chapter Five suggest that students were able to develop bridging and bonding social capital, as well as empathy. This is evident in the empirical data; however, the qualitative 
responses of all chapters suggest that students are reflecting upon their experiences and are being exposed to non-traditional modes of education. Therefore, students need to be challenged on their preconceived ideas and this can occur through the use of activities outside of the classroom. This is easier to accomplish with experiential education, because students must leave the classroom in order to complete course requirements. This puts students in direct contact with individuals who may not be like them - thus, exposing them to divergent viewpoints.

3. Learning is Reflecting - educators need to enable student reflection to occur. Without that reflection, it is difficult, if not impossible, for students to challenge some of their preconceived notions. The specific word clouds presented in this research lend support to the idea that students need an outlet to reflect on what they are taking in, both inside and outside the classroom. Therefore, educators should place mechanisms within their course to enable that reflection to occur. Whether it be journaling or discussion boards, it is important for students to process what they are actually learning.

As mentioned, the qualitative responses of Chapters Three, Four and Five suggest that students may be getting even more out of experiential education and other innovative teaching techniques than the data indicates. Within all of the courses that used these methods, students were asked to reflect on what they learned, whether during in-class discussions and/or presentations. Educators need to structure course activities around the incorporation of reflection. Merely having students learn in a different way may lead to citizen development, but asking the student to reflect on what they encountered should lead to a more engaging and fulfilling experience for students and educators.

4. Learning is Holistic - All too often, it seems that higher education places a premium on a student's success, specifically tied to academic performance. But, what does that actually 
mean. Instead, learning needs to encapsulate the total student experience. Using experiential education and other innovative teaching techniques allows students to understand complex ideas and theories in practice, outside of the confines of a classroom. While this does not mean that traditional learning is bad, it does mean that educators need to understand that students are different today than they were even 20 years ago. Therefore, it is necessary to change the way an education is being delivered to students.

Chapter Five focuses on learning that specifically exposes students to people in the "other." Students must think about their own circumstances in contrast to those other individuals. In so doing, students are engaging with their thoughts, feelings, and actions. Empathy obviously plays a direct role in a student's thoughts and feelings, and could potentially lead to actions. The data in Chapter Five reinforces the idea that educators should also focus on empathy development in the hopes of developing citizens. As the research indicated, empathy makes students more likely to care about the plight of others, and that notion is reinforced by the increase in bridging and bonding social capital that is also exhibited within Chapter Five's data analysis.

5. Learning and Synergetic Transactions - This means that experiences help students to understand existing concepts and actually learn more. As Chapters Three and Four, continued exposure to experiential education is beneficial for students. Also, this reinforces the notion that educators do not need to abandon traditional means of content delivery. Lectures provide the important building blocks for a students' education, but those lectures can, and should, be supplemented with other teaching techniques.

The significance of repeated exposure to experiential education and innovative teaching techniques is evident across all three empirical chapters. What this suggests is that more 
opportunities need to exist for that exposure to occur. Educators need to be incentivized to use this type of education, but they also need to work with each other in order to develop more opportunities for students experience this learning. Additionally, institutions need to promote this learning by incentivizing faculty to incorporate this into their courses. This can be done through a variety of measures, but until there is institutional support, individual educators should focus on this incorporation as much as possible.

6. Learning Creates Knowledge - Learning cannot be viewed as a static enterprise that only occurs in the classroom. Instead, students need to be exposed to as many real-life experiences as possible because it enables them to draw clear connections between concepts and practice. Students should be challenged on their existing views, because those challenges create knowledge. However, to do that, it is necessary to implement more effective teaching techniques. The development of empathy and bridging and bonding social capital, shows that students need to be challenged on their values and beliefs. This is especially important for students who do not have the opportunity or financial means to be exposed to individuals that are different than them. While it was mentioned that innovative teaching, like VR, cannot replace traditional experiences, like study abroad, it can provide an alternative to engage more students. Educators need to think of ways to challenge students, while exposing them to alternative viewpoints. The VR videos used in this research exposed students to situations and people that they may never have thought or cared about. This is important - especially in light of current events. Educators need to think about the stories that are being told, who is telling those stories, and how students can be exposed to as many stories as possible. This will create knowledge that should then lead to more developed citizens. 


\section{Using Experiential Education}

The open-ended responses collected as part of this research suggests that students are gaining valuable skills. As discussed previously, it cannot always be the goal of the educator to teach toward data attainment. There are far too many variables that cannot be controlled for in situations like this, and it would be unfair to completely disregard what student responses show. Therefore, it is important that more work be conducted on the use of experiential education. As Hunter and Brisbin (2000) found, experiential education cannot be expected to fix all of the problems that arise when focusing on the civic education of students. If educators think of experiential education as a one size fits all fix to citizen development, they could be extremely disappointed with the outcomes.

Instead, experiential education needs to be constantly evaluated and its effectiveness reassessed. What works well in one semester, or even for one class, may not yield similar results in student attainment. Educators need to be willing to seek out student reflection on the execution of this type of teaching method; but more importantly, they must be ready to change how they implement it, even if it creates more work.

What's more interesting the impact that continued exposure to experiential education has on a student's ability to increase social capital. Recalling the data in Chapter Three and Four, respondents who indicated additional exposure to experiential education also had higher social capital scores. This means that repeated exposure is important and that experiential education cannot be used as a one-time fix for student engagement. Educators across multiple disciplines need to work together to use experiential education as much as possible, hopefully in a coordinated way, to increase as much benefit to the student as possible. 


\section{Using Innovative Teaching Techniques Like VR}

Innovation is only truly innovative because it changes. By the time VR was being integrated into political science classrooms, video game companies were using the technology so players could "experience" first-player type games. This means that using these techniques requires a mindful educator who is willing to keep abreast of changing technology and be willing to disregard what worked in the past. As evidenced in Chapter Five, VR was useful for students because they were able to see theories, concepts, and situations play out in a way that typical book reading or film watching could not provide. Still, that does not mean that VR is the definitive innovative technique to be employed in classrooms. This research merely seeks to engage political science educators with the understanding that students may learn better and engage with the material if it presented in an immersive way.

\section{Role of the Educator}

The previous sections highlight that the role of the educator is to adapt. Merely having the attitude that something was successful in the past, therefore it will be successful now, will not always work. As educators the focus should be on the student experience as much as the information that is conveyed to the students through traditional means. Yes, it is important that students understand concepts and theories as the framework for the field in general, but if one can make it easier and more attainable for students to comprehend those ideas, why wouldn't that be employed in a course? Trying to get students to become more civically engaged is going to take more action on the part of educators and institutions of learning than merely encouraging them to vote or to watch a presidential debate. One can continue to lament the lack of student engagement, or one can force students to engage with material; however, this requires continued reflection and assessment of one's own teaching. 


\section{Final Thoughts}

There is little doubt that confusion and controversy surround social capital, and to a lesser extent experiential education and other forms of innovative teaching techniques. However, that does not immediately disqualify any of those from being researched. As the previous research indicates, many have researched and discussed experiential education, and they were able to highlight many of the successes that are attributed to this form of education. The research on the social capital side seems to center around 3 debates: whether social capital is what Putnam describes; if it is what Putnam describes, is it actually in decline; or is what sociologists describe. The research presented in the social capital section addressed those concerns and the research model was adjusted, as will be evident in subsequent chapters.

Colleges and universities are now, more than ever, deciding what their mission should be. However, there is little debate that one of the missions is the community engagement/citizenship factor that many term the "third mission." While many universities (land-grant) began as a way to help ensure a more engaged populous, almost all universities and colleges have adopted this mantra. As a result, it should not be surprising that many citizens look to institutions of higher education in order to create better citizens.

Combining experiential education and social capital development has not been adequately explored in order to understand if there is a true benefit that exists between the two. Focusing on these areas presents an opportunity to more clearly define experiential education and social capital in the hopes that a more generalizable view of each can be discussed on college campuses across the U.S. The understanding of experiential education's role in helping to create more engaged citizens is important as the $21^{\text {st }}$ century continues. If Putnam is to be believed, something has to happen in order to help reverse the downtrend of social capital, 
especially among our youth. However, only additional research into this area will yield any real results that are tangible for the people at institutions making decisions on what mission to focus on. As it currently stands, without this research, service-learning and other types of experiential education will not succeed since universities are being asked to look at the bottom line. This research builds the argument that experiential education is vital on college campuses because it helps to increase social capital, which in turn creates better, more engaged citizens. Furthermore, this research implores educators to do their own self-reflection in order to understand that they may need to do more to engage citizens. As educators one has their own civic duty, and that is the development of citizens. That is the role of an educator and one's own idea of a citizen. Without continued self-reflection and course development, it is difficult to see how educators can engage students in democracy. Therefore, everyone needs to be prepared to learn and grow as institutions attempt to tackle the idea of a citizen. 


\section{References}

Association for Experiential Education. 2018. "What is Experiential Education?" https://www.aee.org/what-is-ee (November 1, 2018).

Astin, Alexander W. and Linda J Sax. 1998. "How Undergraduates Are Affected by Service Participation." Journal of College Student Development 39(3): 251-263.

Astin, Alexander W., Linda J. Sax, and Juan Avalos. 1999. "Long-term effects of volunteerism during the undergraduate years." The Review of Higher Education 22(2): 187-202.

Astin, Alexander W., Lori J. Vogelgesang, Elaine K. Ikeda, and Jennifer A. Yee. 2000. "How Service Learning Affects Students." Higher Education.

Astin, Alexander W., Lori J. Vogelgesang, Kimberly Misa, Jodi Anderson, Nita Denson, Uma Jayakumar, Victor Saenz, and Erica Yamamura. 2006. "Understanding the effects of service-learning: A study of students and faculty." A Report to the Atlantic Philanthropies.

Austin, M. Jill and Dianna Zeh Rust. 2015. "Developing an Experiential Learning Program: Milestones and Challenges." International Journal of Teaching and Learning in Higher Education 27.1: 143-153.

Bonnen, James T. 1998. "The Land Grant Idea and the Evolving Outreach University.” In University-community collaborations for the twenty-first century: Outreach scholarship for youth and families, eds. Richard M. Lerner and Lou Anna K. Simon. New York: Garland.

Bringle, Robert G. and Julie A. Hatcher. 1996. "Implementing Service Learning in Higher Education." The Journal of Higher Education 67(2): 221-239.

Bringle, Robert G., \& Patti H. Clayton. 2012. "Civic Education through Service Learning: What, How, and Why?." In Higher Education and Civic Engagement, eds. Lorraine Mcilrath, Anny Lyons, and Ronaldo Munck. New York: Palgrave Macmillan US, 101-124.

Building the Service Learning Pyramid. (n.d.). Campus Compact. Retrieved from http://compact.org/resource-posts/building-the-service-learning-pyramid-2/.

Campbell, David E. 2000. "Social Capital and Service Learning." PS: Political Science and Politics 33(3): 641-645.

Coleman, James. 1988. "Social Capital in the Creation of Human Capital." American Journal of Sociology 94: S95-S120.

De Tocqueville, Alexis. 2004. Democracy in America. New York: The Library of America. 
Dewey, John. 1938. Experience and Education New York: Simon \& Schuster.

Dvorak, Bruce I., Benjamin A. Stewart, Ahmed A. Hosni, Stacey A. Hawkey, and Valdeen Nelson. 2011. "Intensive environmental sustainability education: Long-term impacts on workplace behavior." Journal of Professional Issues in Engineering Education and Practice, 137(2): 113-120.

Ellison, Nicole B, Jessica Vitak, Rebecca Gray, and Cliff Lampe. 2014. "Cultivating Social Resources on Social Network Sites: Facebook Relationship Maintenance Behaviors and Their Role in Social Capital Processes." Journal of Computer-Mediated Communication 4(1): 855-870.

Engbers, Trent A., Michael F. Thompson, and Timothy F. Slaper. 2017. "Theory and measurement in social capital research." Social Indicators Research 132.2: 537-558.

Ewert, Alan and Jim Sibthorp. 2009. "Creating Outcomes Through Experiential Education: The Challenge of Confounding Variables." Journal of Experiential Education 31.3: 376-389.

Farr, James. 2004. "Social Capital: A Conceptual History.” Political Theory 32 (1): 6-33.

Fenzel, Mickey L. and Mark Peyrot. 2005. "Comparing college community participation and future service behaviors and attitudes." Michigan Journal of Community Service Learning 12(1): 23-31.

Freeland, Richard. 2018. "Yes, Higher Ed Is a Business, But It's Also a Calling." https://www.chronicle.com/article/Yes-Higher-Ed-Is-a-Business/242852 (June 20, 2019).

Fullerton, Ann, Vicki L. Reitenauer, and Seanna M. Kerrigan. 2015. "A Grateful Recollecting: A Qualitative Study of the Long-Term Impact of Service-Learning on Graduates." Journal of Higher Education Outreach and Engagement 19(2): 65-92.

Furco, Andrew. 1996. "Service-learning: A balanced approach to experiential education. In Expanding Boundaries: Serving and Learning, ed. B. Taylor. Washington, DC: Corporation for National Service, 2-7.

Gallatin, J., \& Adelson, J. 1970. "Individual rights and the public good: A cross-national study of adolescents." Comparative Political Studies (3): 226-244.

Gunnell, John G. 1993. The Descent of Political Theory. Chicago: The University of Chicago Press.

Hakhverdian, Armen and Quinton Mayne. 2012. "Institutional Trust, Education, and Corruption: A Micro-Macro Interactive Approach." The Journal of Politics 74.3: 739-750. 
Hammond, C. 1994. "Integrating service and academic study: Faculty motivation and satisfaction in Michigan higher education." Michigan Journal of Community Service Learning 1(1): 21-28.

Hanifan, L. J. 1912. "Rural School Report." Biennial Report of the State Superintendent of Free Schools of West Virginia. Charleston, WV: State Department of Education.

Hanifan, L. J. 1914. "Negro Education.” Biennial Report of the State Superintendent of Free Schools of West Virginia. Charleston, WV: State Department of Education.

Hanifan, L. J. 1916. "Report of the State Supervisor of rural schools." Biennial Report of the State Superintendent of Free Schools of West Virginia. Charleston, WV: State Department of Education.

Harris, Clodagh. 2010. "Active Democratic Citizenship and Service-Learning in the Postgraduate Classroom.” Journal of Political Science Education 6(3): 227-243.

Helwig, C. 1995. “Adolescents' and young adults' conceptions of civil liberties: Freedom of speech and religion." Child Development (66): 152-166.

Helwig, C. 1997. "The role of agent and social context in judgments of freedom of speech and religion." Child Development (68): 484-495.

Hunter, Susan and Richard A. Brisbin. 2000. "The Impact of Service Learning on Democratic and Civic Values." PS: Political Science and Politics 33.3: 623-626.

$\mathrm{Hu}-\mathrm{Au}$, Elliot and Joey J. Lee. 2017. "Virtual reality in education: a tool for learning in the experience age." Int. J. Innovation in Education 4.4: 215-226.

Kahne, Joseph, Bernadette Chi and Ellen Middaugh. 2006. "Building Social Capital for Civic and Political Engagement: The Potential of High-School Civics Courses." Canadian Journal of Education 29.2 387-409.

Kenny, Maureen and Laura A. Gallagher. 2002. "Service-Learning: A History of Systems." In Learning to Serve, eds. Maureen Kenny, Lou Anna K. Simon, Karen Kiley-Brabeck, and Richard M. Lerner. Boston: Kluwer Academic Publishers, 15-29.

Kenny, Maureen, Lou Anna K. Simon, Karen Kiley-Brabeck, and Richard M. Lerner. 2002. "Promoting Civil Society through Service Learning: A View of the Issues." In Learning to Serve, eds. Maureen Kenny, Lou Anna K. Simon, Karen Kiley-Brabeck, and Richard M. Lerner. Boston: Kluwer Academic Publishers, 1-13.

Klesner, Joseph L. 2007. "Social Capital and Political Participation in Latin America: Evidence from Argentina, Chile, Mexico, and Peru." Latin American Research Review 42.2: 1 32. 
Kolb, Alice Y. and David A. Kolb. 2005. "Learning Styles and Learning Spaces: Enhancing Experiential Learning in Higher Education" Academy of Management Learning \& Educaton 4.2: 193-212.

Konrath, Sara H., Edward H. O’Brien, and Courtney Hsing. 2011. "Changes in Dispositional Empathy in American College Students Over Time: A Meta-Analysis." Personality and Social Psychology Review 15.2: 180-198.

Kozlowska, Hanna. 2015. "The UN is using virtual reality and an immersive "wormhole" to connect diplomats with Syrian refugees.” QZ.com Sept 21, 2015.

Krishna, Anirudh. 2002. "Enhancing Political Participation in Democracies: What is the Role of Social Capital?" Comparative Political Studies 35.4: 437-460.

Kuh, G.D. 2008. High educational impact practices: What they are, who has access to them and why they matter? Washington, DC: AAC\&U.

La Due Lake, Ronald and Robert Huckfeldt. 1998. "Social capital, social networks, and political participation." Political Psychology 19(3): 567-584.

Lerner, Richard M. and Lou Anna K. Simon. 1998. University-community collaborations for the twenty-first century: Outreach scholarship for youth and families. New York: Garland.

Lemann, Nicolas. 1996. "Kicking in Groups.” The Atlantic Monthly 277 (4): 22-26.

Lorenzini, Michelle. 2013. "From Active Service to Civic and Political Engagement: Fighting the Problem of Poverty." In Teaching Civic Engagement: From Student to Active Citizen, eds. Alison Rios Millett McCartney, Elizabeth A. Bennion, and Dick Simpson. Washington: American Political Science Association, 119-136.

MacFall, Janet. 2012. "Long-term impact of service learning in environmental studies." Journal of College Science Teaching, 41(3), 26-31.

Mahoney, B.A. and Michael S. Retallick. 2015. "The Impact of Two Experiential Learning Programs: The Graduates' Perspective." Agricultural Education and Studies Publications (59)4: 319-325.

Mann, Christopher B. et al. 2018. "Pedagogical Value of Polling-Place Observation by Students.” PS: Political Science \& Politics 51(4): 831-37.

McClurg, Scott. 2003. "Social Networks and Political Participation: The Role of Social Interaction in Explaining Political Participation." Political Research Quarterly 56: 448464. 
McCartney, Alison Rios Millett. 2013. "Teaching Civic Engagement: Debates, Definitions, Benefits and Challenges." In Teaching Civic Engagement: From Student to Active Citizen, eds. Alison Rios Millett McCartney, Elizabeth A. Bennion, and Dick Simpson. Washington: American Political Science Association, 9-20.

McCartney, Alison Rios Millett and Sivan Chaban. 2013. "Bringing the World Home: Effectively Connecting Civic Engagement and International Relations.” In Teaching Civic Engagement: From Student to Active Citizen, eds. Alison Rios Millett McCartney, Elizabeth A. Bennion, and Dick Simpson. Washington: American Political Science Association, 259-278.

McIntosh, Daniel. 2001. "The Uses and Limits of the Model United Nations in an International Relations Classroom.” International Studies Perspectives 2: 269-280.

McKinlay, Patrick F. 2013. "Political Hermeneutics as Pedagogy: Service-Learning, Political Reflection, and Action." In Teaching Civic Engagement: From Student to Active Citizen, eds. Alison Rios Millett McCartney, Elizabeth A. Bennion, and Dick Simpson. Washington: American Political Science Association, 229-246.

Metzger, Aaron and Smetana, J. G. 2010. "Social Cognitive Development and Adolescent Civic Engagement. In Handbook of Research on Civic Engagement in Youth, eds. L. R. Sherrod, J. Torney-Purta and C. A. Flanagan. Hoboken, NJ: John Wiley \& Sons, Inc.

Mitchell, Tania D., F. Dan Richard, Richard M. Battistoni, Colleen Rost-Banik, Rebecca Netz, and Catherine Zakoske. 2015. "Reflective Practice that Persists: Connections Between Reflection in Service-Learning Programs and in Current Life." Michigan Journal of Community Service Learning Spring: 49-63.

Molenberghs, Pascal. 2017. "This is what empathy really is, and why we need it." World Economic Forum: https:/www.weforum.org/agenda/2017/01/this-is-what-empathyreally-is-and-why-we-need-it?utm_content=buffer8e5f2\&utm_medium $=$ social\&utm_source=twitter.com\&utm_campaign=buffer.

Morgan, W., \& Streb, M. 2001. "Building citizenship: how student voice in service-learning develops civic values.” Social Science Quarterly 82(1): 154-169.

Morone, James A. 1998. The Democratic Wish. New Haven: Yale University Press.

Newfield, Christopher. 2016. The Great Mistake. Baltimore: Johns Hopkins University Press.

Newman, Cynthia M.. and Sidfredo A. Hernandez. 2011. "Minding our business: Longitudinal effects of a service learning experience on alumni." Journal of College Teaching \& Learning 8(8): 39-48.

Peterson, Andrew. 2011. Civic Republicanism and Civic Education: The Education of Citizens. London: Palgrave Macmillan. 
Portes, Alejandro. 1998. "Social capital: its origins and applications in modern sociology." Annual Review Sociology 24:1-24.

Portes, Alejandro and Erik Vickstrom. 2011. "Diversity, Social Capital, and Cohesion." Annual Review Sociology 37: 461-79.

Psotka, Joseph. 1995. "Immersive training systems: Virtual reality and education and training." Instructional Science 23.5/6: 405-431.

Putnam, Robert D. 1995a. "Tuning in, tuning out: The strange disappearance of social capital in America." PS: Political Science \& Politics 28: 664-683.

Putnam, Robert D. 1995b. "Bowling alone, revisited. The Responsive Community 5(2): 1833.

Putnam, Robert D. 1995c. "Bowling Alone: America's Declining Social Capital. Journal of Democracy 6: 65-78.

Putnam, Robert D. 2000. Bowling Alone: The Collapse and Revival of American Community New York: Simon \& Schuster.

Reinders, Heinz and James Youniss. 2006. "School-Based Required Community Service and Civic Development in Adolescents." Applied Developmental Science 10(1): 2-12.

Reniers, Renate L. E. P., Rhiannon Corcoran, Richard Drake, Nick M. Shryane and Birgit A. Vollm. 2011. "The QCAE: A Questionnaire of Cognitive and Affective Empathy." Journal of Personality Assessment 93.1: 84-95.

Rios Millett McCartney, Alison and Sivan Chaban. 2013. "Bringing the World Home: Effectively Connecting Civic Engagement and International Relations." In Teaching Civic Engagement: From Student to Active Citizen, eds. Alison Rios Millett McCartney, Elizabeth A. Bennion, and Dick Simpson. Washington: American Political Science Association, 259-278.

Roberts, Margaret E., Stewart, Brandon M., Tingley, Dustin, Lucas, Christopher, Luder-Luis, Jetson, Gadarian, Shana Kushner, Albertson, Bethany, and Rand, David G.. 2014. "Structural Topic Models for Open-Ended Survey Responses." American Journal of Political Science 58 (4): 1064-82.

Saltmarsh, John and Matthew Hartley. 2011. "Democratic Engagement." In "To Serve A Larger Purpose," eds. John Saltmarsh and Matthew Hartley. Philadelphia: Temple University Press, 14-26.

Schuetze, Hans G. 2012. "Universities and Their Communities - Engagement and Service as Primary Mission." In Higher Education and Civic Engagement, eds. Lorraine Mcilrath, Ann Lyons, and Ronaldo Munck. New York: Palgrave Macmillan, 61-77. 
Smith, Elizabeth S. 2006. "Learning about Power through Service: Qualitative and Quantitative Assessments of a Service-Learning Approach to American Government." Journal of Political Science Education 2(2): 147-170.

Smith, Stephen Samuel and Jessica Kulynych. 2002. "It May Be Social, but Why Is It Capital? The Social Construction of Social Capital and the Politics of Language." Politics \& Society 30(1): 149-186.

Swanbrow, Diane. 2010. "Empathy: College students don't have as much as they used to." Michigan News: http://ns.umich.edu/new/releases/7724-empathy-college-students-don-thave-as-much-as-they-used-to.

Thomas, Nancy, Adam Gismondi, Prabhat Gautam and David Brinker. 2019. "Democracy Counts 2018: Increased Student and Institutional Engagement." Institute for Democracy \& Higher Education.

U.S. Department of Labor. Bureau of Labor Statistics. 2018. College Enrollment and Work Activity of Recent High School and College Graduates Summary. Washington, D.C.: Department of Labor

Various. 2012. A Crucible Moment: College Learning \& Democracy's Future. The National Taskforce on Civic Learning and Democratic Engagement.

Vogelgesang, Lori J. and Astin, Alexander W. 2000. "Comparing the Effects of Community Service and Service-Learning." Michigan Journal of Community Service Learning 7(1): 25-34.

Warchal, Judith, and Ana Ruiz. 2004. "The long term effects of undergraduate service-learning programs on postgraduate employment choices, community engagement and civic leadership." New perspectives in service-learning: Research to advance the field 4: 8716.

Williams, Dmitri. 2006. "On and Off the "Net: Scales for Social Capital in an Online Era." Journal of Computer-Mediated Community 11.2: 593-628.

Wilson, Patricia A. 1997. "Building Social Capital: A Learning Agenda for the Twenty-first Century.” Urban Studies 34.5-6: 745-760.

Wilson, Woodrow. 1925. "A System of Political Science and Constitutional Law." In The Public Papers of Woodrow Wilson College and State, eds. Ray Stannard Baker and William E. Dodd, 187-197 . Harper \& Brothers Publishing: New York and London. 
Zinshteyn, Mikhail. 2016. "Have Public Universities Lost Their Focus?" https://www.theatlantic.com/education/archive/2016/11/have-public-universities-losttheir-focus/508424/ (November 22, 2016). 
Appendix A -

Developing Social Capital Using Experiential Education Questionnaire

\section{Demographic Questions:}

Question 1: What is your gender?

1. Male

2. Female

3. Decline to state

Question 2: What is your age?

1. 18

2. 19

3. 20

4. 21

5. 22

6. 23

7. 24

8. 25

9. 26 or greater

Question 3: Please choose one or more races that you consider yourself to be:

- white;

- black or African-American;

- American Indian or Alaska Native;

- Asian; or

- Native Hawaiian or other Pacific Islander?

1. White

2. Black or African-American

3. American Indian or Alaska Native

4. Asian

5. Native Hawaiian or other Pacific Islander

Question 4: Are you Spanish, Hispanic, or Latino?

1. Yes

2. No

Question 5: What state do you reside in, when not attending college?

1. Alabama

2. Alaska

3. Arizona

4. Arkansas

5. California

6. Colorado

7. Connecticut

8. Delaware

9. District of Columbia 
10. Florida

11. Georgia

12. Hawaii

13. Idaho

14. Illinois

15. Indiana

16. Iowa

17. Kansas

18. Kentucky

19. Louisiana

20. Maine

21. Maryland

22. Massachusetts

23. Michigan

24. Minnesota

25. Mississippi

26. Missouri

27. Montana

28. Nebraska

29. Nevada

30. New Hampshire

31. New Jersey

32. New Mexico

33. New York

34. North Carolina

35. North Dakota

36. Ohio

37. Oklahoma

38. Oregon

39. Pennsylvania

40. Rhode Island

41. South Carolina

42. South Dakota

43. Tennessee

44. Texas

45. Utah

46. Vermont

47. Virginia

48. Washington

49. West Virginia

50. Wisconsin

51. Wyoming

52. I do not reside in the United States

Question 6: How would you describe your social class? Are you in the lower class, the working class, lower middle class, upper middle class, or the upper class? 
1. Lower class or poor

2. Working class

3. Lower middle class

4. Upper middle class

5. Upper class

Question 7: How many credit hours have you earned towards your bachelor's degree?

1. $0-28$ hours

2. $29-58$ hours

3. $59-88$ hours

4. $89+$ hours

Question 8: What is your overall GPA?

1. $4.0-3.5$

2. $3.49-3.0$

3. $2.99-2.5$

4. $2.49-2.0$

5. 1.9 and below

Question 9: What is your current major?

1. Accounting

2. Acting

3. Aerospace Engineering

4. Agribusiness Management

5. Agricultural and Extension Education

6. Agroecology

7. Animal and Nutritional Sciences

8. Anthropology

9. Applied and Environmental Microbiology

10. Art Education

11. Art History

12. Athletic Coaching Education

13. Athletic Training

14. Biochemistry

15. Biology (B.A.)

16. Biology (B.S.)

17. Biomedical Engineering

18. Biometric Systems

19. Ceramics

20. Chemical Engineering

21. Chemistry (B.A.)

22. Chemistry (B.S.)

23. Child Development and Family Studies

24. Civil Engineering

25. Communication Studies

26. Computer Engineering 
27. Computer Science

28. Criminology

29. Dance

30. Dental Hygiene

31. Design Studies

32. Economics (B.A.)

33. Economics (B.S.)

34. Electrical Engineering

35. Elementary Education

36. Energy Land Management

37. English

38. Entrepreneurship and Innovation

39. Environmental and Energy Resources Management

40. Environmental and Natural Resource Economics

41. Environmental Geoscience

42. Environmental, Soil and Water Sciences

43. Exercise Physiology

44. Fashion, Dress and Merchandising

45. Finance

46. Forensic and Investigative Science

47. Forest Resources Management

48. General Business

49. Geography

50. Geology

51. Global Supply Chain Management

52. Graphic Design

53. Health Informatics and Information Management

54. History

55. Horticulture

56. Hospitality and Tourism Management

57. Human Nutrition and Foods

58. Immunology and Medical Microbiology

59. Industrial Engineering

60. Integrative and Contemporary Performance

61. Interdisciplinary Studies

62. Interior Design

63. Intermedia and Photography

64. International Studies

65. Journalism

66. Landscape Architecture

67. Latin American Studies

68. Management

69. Management Information Systems

70. Marketing

71. Mathematics (B.A.)

72. Mathematics (B.S.) 
73. Mechanical Engineering

74. Medical Laboratory Science

75. Mining Engineering

76. Multidisciplinary Studies (Creative Arts)

77. Multidisciplinary Studies (Davis College)

78. Multidisciplinary Studies (Eberly)

79. Multidisciplinary Studies (Education and Human Services)

80. Multidisciplinary Studies (Physical Activity and Sport Sciences)

81. Multidisciplinary Studies (Reed College)

82. Music

83. Music Composition

84. Music Education

85. Music Industry

86. Music Performance: Instrumental

87. Music Performance: Jazz Studies

88. Music Performance: Piano

89. Music Performance: Voice

90. Music Performance: Woodwinds

91. Music Therapy

92. Musical Theatre

93. Nursing

94. Occupational Therapy

95. Painting

96. Petroleum and Natural Gas Engineering

97. Philosophy

98. Photography

99. Physical Education Teacher Education

100. Physics (B.A.)

101. Physics (B.S.)

102. Political Science

103. Pre-Pharmacy

104. Printmaking

105. Psychology (B.A.)

106. Psychology (B.S.)

107. Public Health

108. Puppetry

109. Recreation, Parks and Tourism Resources

110. Regents B.A.

111. Religious Studies

112. Sculpture

113. Slavic and Eastern European Studies

114. Social Work

115. Sociology

116. Speech Pathology and Audiology

117. Sport and Exercise Psychology

118. Sport Management 
119. Strategic Communications

120. Theatre

121. Theatre Design and Technology

122. Wildlife and Fisheries Resources

123. Women's and Gender Studies

124. Wood Science and Technology

125. World Languages, Literature, and Linguistics

126. Undecided/Undeclared

127. Other

Question 10: If you selected other, please identify your major in the field below.

(Open-Ended)

Question 11: In which of the following classes are you currently enrolled? Select all that apply.

1. COMM 112: Small Group Communication

2. LDR 201: Principles of Leadership

3. MDS 489: Capstone

4. POLS 491A: Prof Fld Expr: Model U.N.

Question 12: Before this semester, have you ever taken a class that required you to do servicelearning as part of your grade?

1. Yes

2. No

3. I don't remember

Question 13: If you answered yes to the previous questions, in what class or classes did this occur?

(Open-Ended)

Question 14: Before this semester, have you ever taken a class that required you to do community service as part of your grade?

1. Yes

2. No

3. I don't remember

Question 15: If you answered yes to the previous questions, in what class or classes did this occur?

(Open-Ended)

Question 16: Before this semester, have you ever taken a class that required you to do an internship as part of your grade?

1. Yes

2. No

3. I don't remember 
Question 17: If you answered yes to the previous questions, in what class or classes did this occur?

(Open-Ended)

Question 18: Before this semester, have you ever taken a class that required you to do professional field experience as part of your grade?

1. Yes

2. No

3. I don't remember

Question 19: If you answered yes to the previous questions, in what class or classes did this occur?

(Open-Ended)

\section{Post-Test Only Questions:}

Question 1: During the semester, did you complete community service, service-learning, professional field experience, or an internship for a class as part of your grade?

1. Yes

2. No

3. I don't remember

Question 2: If you answered yes to the previous question, in what class or classes did this occur and did you do community service, service-learning, professional field experience, or an internship in that class(es)?

Question 3: If you completed community service this semester as part of one of your classes, what was the best part about that experience? If you did not do community service in one of your classes, you should skip this question.

Question 4: If you completed community service this semester as part of one of your classes, what was the worst part about that experience? If you did not do community service in one of your classes, you should skip this question.

Question 5: If you completed community service this semester as part of one of your classes, what did you learn as a result of that experience? If you did not do community service in one of your classes, you should skip this question.

Question 6: If you completed service-learning this semester as part of one of your classes, what was the best part about that experience? If you did not do service-learning in one of your classes, you should skip this question.

Question 7: If you completed service-learning this semester as part of one of your classes, what was the worst part about that experience? If you did not do service-learning in one of your classes, you should skip this question. 
Question 8: If you completed service-learning this semester as part of one of your classes, what did you learn as a result of that experience? If you did not do service-learning in one of your classes, you should skip this question.

Question 9: If you completed professional field experience this semester as part of one of your classes, what was the best part about that experience? If you did not do professional field experience in one of your classes, you should skip this question.

Question 10: If you completed professional field experience this semester as part of one of your classes, what was the worst part about that experience? If you did not do professional field experience in one of your classes, you should skip this question.

Question 11: If you completed professional field experience this semester as part of one of your classes, what did you learn as a result of that experience? If you did not do professional field experience in one of your classes, you should skip this question.

Question 12: If you completed an internship this semester as part of one of your classes, what was the best part about that experience? If you did not do an internship in one of your classes, you should skip this question.

Question 13: If you completed an internship this semester as part of one of your classes, what was the worst part about that experience? If you did not do an internship in one of your classes, you should skip this question.

Question 14: If you completed an internship this semester as part of one of your classes, what did you learn as a result of that experience? If you did not do an internship in one of your classes, you should skip this question.

\section{Pre and Post Test Social Capital Questions:}

Question 1: During the past 4 years, have you joined in a protest march, rally, or demonstration, or have you not done this in the past 4 years?

1. Yes, I have done this in the past 4 years.

2. No, I have not done this in the past years.

3. I don't know

Question 2: During the past 4 years, have you attended a meeting of a town or city government or school board, or have you not done this in the past 4 years?

1. Yes, I have done this in the past 4 years.

2. No, I have not done this in the past years.

3. I don't know

Question 3: During the past 4 years, have you signed a petition on the Internet about a political or social issue, or have you not done this in the past 4 years?

1. Yes, I have done this in the past 4 years.

2. No, I have not done this in the past years.

3. I don't know 
Question 4: During the past 4 years, have you signed a petition on paper about a political or social issue, or have you not done this in the past 4 years?

1. Yes, I have done this in the past 4 years.

2. No, I have not done this in the past years.

3. I don't know

Question 5: Not counting a religious organization, during the past 4 years, have you given money to any other organization concerned with a political or social issue, or have you not done this in the past 4 years?

1. Yes, I have done this in the past 4 years.

2. No, I have not done this in the past years.

3. I don't know

Question 6: During the past 4 years, have you called a radio or TV show about a political issue, or have you not done this in the past 4 years?

1. Yes, I have done this in the past 4 years.

2. No, I have not done this in the past years.

3. I don't know

Question 7: During the past 4 years, have you ever sent a message on Facebook or Twitter about a political issue, or have you not done this in the past 4 years?

1. Yes, I have done this in the past 4 years.

2. No, I have not done this in the past years.

3. I don't know

Question 8: During the past 4 years, have you written a letter to a newspaper or magazine about a political issue, or have you not done this in the past 4 years?

1. Yes, I have done this in the past 4 years.

2. No, I have not done this in the past years.

3. I don't know

Question 9: During the past 4 years, have you contacted or tried to contact a member of the U.S. Senate or U.S. House of Representatives, or have you not done this in the past 4 years?

1. Yes, I have done this in the past 4 years.

2. No, I have not done this in the past years.

3. I don't know

Question 10: During the PAST 12 MONTHS, have your worked with other people to deal with some issue facing your community?

1. Yes

2. No

3. I don't know

Question 11: During the PAST 12 MONTHS, have you telephoned, written a letter to, or visited a government official to express your views on a public issue? 
1. Yes

2. No

3. I don't know

Question 12: During the PAST 12 MONTHS, did you attend a meeting about an issue facing your community or schools?

1. Yes

2. No

3. I don't know

Question 13: Many people say they have less time these days to do volunteer work. What about you, were you able to devote any time to volunteer work in the last 12 months or did you not do so?

1. Yes

2. No

3. I don't know

Question 14: Many people are finding it more difficult to make contributions to church or charity as much as they used to. How about you - were you able to contribute any money to church or charity in the past 12 months?

1. Yes

2. No

3. I don't know

Question 15: Did you vote for a candidate for President in the 2016 general election?

1. Yes

2. No

3. Was not eligible

4. Don't know

Question 16: Did you vote in the most recent election (primary election 2017) held in the area where you live?

1. Yes

2. No

3. Was not eligible

4. Don't know

Question 17: Do you serve as an officer or committee member in any local organization? This includes on-campus organizations.

1. Yes

2. No

3. I don't know

Question 18: Are you a member of an organization such as hobby clubs, sports teams, community groups, groups working on political issues? This includes both on and off campus organizations. 
1. Yes

2. No

3. I don't know

Question 19: During the past 12 months, have you worked with other people to deal with some issue facing your community?

1. Yes, I have done this in the past 12 months

2. No, I have not done this

3. I don't know

Question 20: Are you a member of a local church, synagogue, or other religious or spiritual community?

1. Yes

2. No

3. I don't know

Question 21: How often do you attend religious services?

1. Every week (or more often)

2. Almost every week

3. Once or twice a month

4. A few times per year

5. Less often than that

Question 22: Do you participate in church activities other than attending services?

1. Yes

2. No

3. I don't know

Question 23: During the past 12 months, have you ever given money to a religious organization, or have you not done this in the past 12 months?

1. Yes, I have done this in past 12 months

2. No, I have not done this in the past 12 months

3. I don't know

Question 24: How often have you had friends over to your home, apartment or dorm room in the past 12 months?

1. Never did this

2. Once

3. A few times

4. 2-4 times

5. 5-9 times

6. About once a month on average

7. Twice a month

8. About once a week on average

9. More than once a week 
Question 25: How often have you visited a friend's home, apartment or dorm room in the past 12 months?

1. Never did this

2. Once

3. A few times

4. 2-4 times

5. 5-9 times

6. About once a month on average

7. Twice a month

8. About once a week on average

9. More than once a week

Question 26: How often did you go out with friends in the last 12 months?

1. Never did this

2. Once

3. A few times

4. 2-4 times

5. 5-9 times

6. About once a month on average

7. Twice a month

8. About once a week on average

9. More than once a week

Question 27: How often can you trust the federal government in Washington to do what is right? 1. Always

2. Most of the time

3. About half the time

4. Some of the time

5. Never

Question 28: How much of the time do you think you can trust the local government to do what is right?

1. Always

2. Most of the time

3. About half the time

4. Some of the time

5. Never

Question 29: How much of the time do you think you can trust the police in your local community?

1. Always

2. Most of the time

3. About half the time

4. Some of the time

5. Never 
Question 30: How often can people be trusted?

1. Always

2. Most of the time

3. About half the time

4. Some of the time

5. Never

Question 31: How often can you trust someone of a different race than you?

1. Always

2. Most of the time

3. About half the time

4. Some of the time

5. Never

Question 32: How often can you trust someone in your neighborhood or on campus residential community?

1. Always

2. Most of the time

3. About half the time

4. Some of the time

5. Never

Pre and Post Test Bridging and Bonding Social Capital Questions:

Respondents could select the following responses to these questions:

1. Strongly agree

2. Somewhat agree

3. Neither agree nor disagree

4. Somewhat disagree disagree

5. Strongly disagree

Question 1: Interacting with people makes me interested in things that happen outside of my town.

Question 2: Interacting with people makes me want to try new things.

Question 3: Interacting with people makes me interested in what people unlike me are thinking. Question 4: Talking with people make me curious about other places in the world.

Question 5: Interacting with people makes me feel like part of a larger community.

Question 6: Interacting with people makes me feel connected to the bigger picture.

Question 7: Interacting with people reminds me that everyone in the world is connected.

Question 8: I am willing to spend time to support general community activities.

Question 9: Interacting with people give me new people to talk to.

Question 10: I come in contact with new people all of the time.

Question 11: There are several people I trust to help solve my problems.

Question 12: There is someone I can turn to for advice about making very important decisions. Question 13: There is no one that I feel comfortable talking to about intimate personal problems. Question 14: When I feel lonely, there are several people I can talk to.

Question 15: If I needed an emergency loan of \$500, I know someone I can turn to. 
Question 16: The people I interact with would put their reputation on the line for me. Question 17: The people I interact with would be good job references for me.

Question 18: The people I interact with would share their last dollar with me.

Question 19: I do not know people well enough to get them to do anything important. Question 20: The people I interact with would help me fight an injustice. 


\section{Appendix B -}

Developing Social Capital Using Experiential Education Questionnaire (Graduates)

\section{Demographic Questions:}

Question 1: What is your gender?

1. Male

2. Female

3. Decline to state

Question 2: What is your age?

1. 18

2. 19

3. 20

4. 21

5. 22

6. 23

7. 24

8. 25

9. 26 or greater

Question 3: Please choose one or more races that you consider yourself to be:

- white;

- black or African-American;

- American Indian or Alaska Native;

- Asian; or

- Native Hawaiian or other Pacific Islander?

1. White

2. Black or African-American

3. American Indian or Alaska Native

4. Asian

5. Native Hawaiian or other Pacific Islander

Question 4: Are you Spanish, Hispanic, or Latino?

1. Yes

2. No

Question 5: What state do you currently reside in?

1. Alabama

2. Alaska

3. Arizona

4. Arkansas

5. California

6. Colorado

7. Connecticut

8. Delaware

9. District of Columbia 
10. Florida

11. Georgia

12. Hawaii

13. Idaho

14. Illinois

15. Indiana

16. Iowa

17. Kansas

18. Kentucky

19. Louisiana

20. Maine

21. Maryland

22. Massachusetts

23. Michigan

24. Minnesota

25. Mississippi

26. Missouri

27. Montana

28. Nebraska

29. Nevada

30. New Hampshire

31. New Jersey

32. New Mexico

33. New York

34. North Carolina

35. North Dakota

36. Ohio

37. Oklahoma

38. Oregon

39. Pennsylvania

40. Rhode Island

41. South Carolina

42. South Dakota

43. Tennessee

44. Texas

45. Utah

46. Vermont

47. Virginia

48. Washington

49. West Virginia

50. Wisconsin

51. Wyoming

52. I do not reside in the United States

Question 6: How would you describe your social class? Are you in the lower class, the working class, lower middle class, upper middle class, or the upper class? 
1. Lower class or poor

2. Working class

3. Lower middle class

4. Upper middle class

5. Upper class

Question 7: What year did you graduate from college?

1. 2014

2. 2015

3. 2016

Question 8: What was your overall GPA?

1. $4.0-3.5$

2. $3.49-3.0$

3. $2.99-2.5$

4. $2.49-2.0$

5. 1.9 and below

Question 9: What was your major?

1. Accounting

2. Acting

3. Aerospace Engineering

4. Agribusiness Management

5. Agricultural and Extension Education

6. Agroecology

7. Animal and Nutritional Sciences

8. Anthropology

9. Applied and Environmental Microbiology

10. Art Education

11. Art History

12. Athletic Coaching Education

13. Athletic Training

14. Biochemistry

15. Biology (B.A.)

16. Biology (B.S.)

17. Biomedical Engineering

18. Biometric Systems

19. Ceramics

20. Chemical Engineering

21. Chemistry (B.A.)

22. Chemistry (B.S.)

23. Child Development and Family Studies

24. Civil Engineering

25. Communication Studies

26. Computer Engineering

27. Computer Science 
28. Criminology

29. Dance

30. Dental Hygiene

31. Design Studies

32. Economics (B.A.)

33. Economics (B.S.)

34. Electrical Engineering

35. Elementary Education

36. Energy Land Management

37. English

38. Entrepreneurship and Innovation

39. Environmental and Energy Resources Management

40. Environmental and Natural Resource Economics

41. Environmental Geoscience

42. Environmental, Soil and Water Sciences

43. Exercise Physiology

44. Fashion, Dress and Merchandising

45. Finance

46. Forensic and Investigative Science

47. Forest Resources Management

48. General Business

49. Geography

50. Geology

51. Global Supply Chain Management

52. Graphic Design

53. Health Informatics and Information Management

54. History

55. Horticulture

56. Hospitality and Tourism Management

57. Human Nutrition and Foods

58. Immunology and Medical Microbiology

59. Industrial Engineering

60. Integrative and Contemporary Performance

61. Interdisciplinary Studies

62. Interior Design

63. Intermedia and Photography

64. International Studies

65. Journalism

66. Landscape Architecture

67. Latin American Studies

68. Management

69. Management Information Systems

70. Marketing

71. Mathematics (B.A.)

72. Mathematics (B.S.)

73. Mechanical Engineering 
74. Medical Laboratory Science

75. Mining Engineering

76. Multidisciplinary Studies (Creative Arts)

77. Multidisciplinary Studies (Davis College)

78. Multidisciplinary Studies (Eberly)

79. Multidisciplinary Studies (Education and Human Services)

80. Multidisciplinary Studies (Physical Activity and Sport Sciences)

81. Multidisciplinary Studies (Reed College)

82. Music

83. Music Composition

84. Music Education

85. Music Industry

86. Music Performance: Instrumental

87. Music Performance: Jazz Studies

88. Music Performance: Piano

89. Music Performance: Voice

90. Music Performance: Woodwinds

91. Music Therapy

92. Musical Theatre

93. Nursing

94. Occupational Therapy

95. Painting

96. Petroleum and Natural Gas Engineering

97. Philosophy

98. Photography

99. Physical Education Teacher Education

100. Physics (B.A.)

101. Physics (B.S.)

102. Political Science

103. Pre-Pharmacy

104. Printmaking

105. Psychology (B.A.)

106. Psychology (B.S.)

107. Public Health

108. Puppetry

109. Recreation, Parks and Tourism Resources

110. Regents B.A.

111. Religious Studies

112. Sculpture

113. Slavic and Eastern European Studies

114. Social Work

115. Sociology

116. Speech Pathology and Audiology

117. Sport and Exercise Psychology

118. Sport Management

119. Strategic Communications 
120. Theatre

121. Theatre Design and Technology

122. Wildlife and Fisheries Resources

123. Women's and Gender Studies

124. Wood Science and Technology

125. World Languages, Literature, and Linguistics

126. Undecided/Undeclared

127. Other

Question 10: If you selected other, please identify your major in the field below.

(Open-Ended)

Question 11: In which of the following classes did you take while enrolled as an undergraduate student? Select all that apply.

1. COMM 112: Small Group Communication

2. LDR 201: Principles of Leadership

3. MDS 489: Capstone

4. POLS 491A: Prof Fld Expr: Model U.N.

Question 12: Have you ever taken a class that required you to do service-learning as part of your grade?

1. Yes

2. No

3. I don't remember

Question 13: If you answered yes to the previous questions, in what class or classes did this occur?

(Open-Ended)

Question 14: Have you ever taken a class that required you to do community service as part of your grade?

1. Yes

2. No

3. I don't remember

Question 15: If you answered yes to the previous questions, in what class or classes did this occur?

(Open-Ended)

Question 16: Have you ever taken a class that required you to do an internship as part of your grade?

1. Yes

2. No

3. I don't remember 
Question 17: If you answered yes to the previous questions, in what class or classes did this occur?

(Open-Ended)

Question 18: Have you ever taken a class that required you to do professional field experience as part of your grade?

1. Yes

2. No

3. I don't remember

Question 19: If you answered yes to the previous questions, in what class or classes did this occur?

(Open-Ended)

\section{Open-Ended Questions:}

Question 1: During your undergraduate study, did you complete community service, servicelearning, professional field experience, or an internship for a class as part of your grade?

1. Yes

2. No

3. I don't remember

Question 2: If you answered yes to the previous question, in what class or classes did this occur and did you do community service, service-learning, professional field experience, or an internship in that class(es)?

Question 3: If you completed community service while enrolled as an undergraduate student as part of one of your classes, what was the best part about that experience? If you did not do community service in one of your classes, you should skip this question.

Question 4: If you completed community service while enrolled as an undergraduate student as part of one of your classes, what was the worst part about that experience? If you did not do community service in one of your classes, you should skip this question.

Question 5: If you completed community service while enrolled as an undergraduate student as part of one of your classes, what did you learn as a result of that experience? If you did not do community service in one of your classes, you should skip this question.

Question 6: Why would you recommend a community service based course to another student?

Question 7: If you completed service-learning while enrolled as an undergraduate student as part of one of your classes, what was the best part about that experience? If you did not do servicelearning in one of your classes, you should skip this question.

Question 8: If you completed service-learning while enrolled as an undergraduate student as part of one of your classes, what was the worst part about that experience? If you did not do servicelearning in one of your classes, you should skip this question. 
Question 9: If you completed service-learning while enrolled as an undergraduate student as part of one of your classes, what did you learn as a result of that experience? If you did not do service-learning in one of your classes, you should skip this question.

Question 10: Why would you recommend a service-learning based course to another student?

Question 11: If you completed professional field experience while enrolled as an undergraduate student as part of one of your classes, what was the best part about that experience? If you did not do professional field experience in one of your classes, you should skip this question.

Question 12: If you completed professional field experience while enrolled as an undergraduate student as part of one of your classes, what was the worst part about that experience? If you did not do professional field experience in one of your classes, you should skip this question.

Question 13: If you completed professional field experience while enrolled as an undergraduate student as part of one of your classes, what did you learn as a result of that experience? If you did not do professional field experience in one of your classes, you should skip this question.

Question 14: Why would you recommend a profession field experience based course to another student?

Question 15: If you completed an internship while enrolled as an undergraduate student as part of one of your classes, what was the best part about that experience? If you did not do an internship in one of your classes, you should skip this question.

Question 16: If you completed an internship while enrolled as an undergraduate student as part of one of your classes, what was the worst part about that experience? If you did not do an internship in one of your classes, you should skip this question.

Question 17: If you completed an internship while enrolled as an undergraduate student as part of one of your classes, what did you learn as a result of that experience? If you did not do an internship in one of your classes, you should skip this question.

Question 18: Why would you recommend an internship based course to another student?

\section{Social Capital Questions:}

Question 1: During the past 4 years, have you joined in a protest march, rally, or demonstration, or have you not done this in the past 4 years?

1. Yes, I have done this in the past 4 years.

2. No, I have not done this in the past years.

3. I don't know

Question 2: During the past 4 years, have you attended a meeting of a town or city government or school board, or have you not done this in the past 4 years?

1. Yes, I have done this in the past 4 years. 
2. No, I have not done this in the past years.

3. I don't know

Question 3: During the past 4 years, have you signed a petition on the Internet about a political or social issue, or have you not done this in the past 4 years?

1. Yes, I have done this in the past 4 years.

2. No, I have not done this in the past years.

3. I don't know

Question 4: During the past 4 years, have you signed a petition on paper about a political or social issue, or have you not done this in the past 4 years?

1. Yes, I have done this in the past 4 years.

2. No, I have not done this in the past years.

3. I don't know

Question 5: Not counting a religious organization, during the past 4 years, have you given money to any other organization concerned with a political or social issue, or have you not done this in the past 4 years?

1. Yes, I have done this in the past 4 years.

2. No, I have not done this in the past years.

3. I don't know

Question 6: During the past 4 years, have you called a radio or TV show about a political issue, or have you not done this in the past 4 years?

1. Yes, I have done this in the past 4 years.

2. No, I have not done this in the past years.

3. I don't know

Question 7: During the past 4 years, have you ever sent a message on Facebook or Twitter about a political issue, or have you not done this in the past 4 years?

1. Yes, I have done this in the past 4 years.

2. No, I have not done this in the past years.

3. I don't know

Question 8: During the past 4 years, have you written a letter to a newspaper or magazine about a political issue, or have you not done this in the past 4 years?

1. Yes, I have done this in the past 4 years.

2. No, I have not done this in the past years.

3. I don't know

Question 9: During the past 4 years, have you contacted or tried to contact a member of the U.S. Senate or U.S. House of Representatives, or have you not done this in the past 4 years?

1. Yes, I have done this in the past 4 years.

2. No, I have not done this in the past years.

3. I don't know 
Question 10: During the PAST 12 MONTHS, have your worked with other people to deal with some issue facing your community?

1. Yes

2. No

3. I don't know

Question 11: During the PAST 12 MONTHS, have you telephoned, written a letter to, or visited a government official to express your views on a public issue?

1. Yes

2. No

3. I don't know

Question 12: During the PAST 12 MONTHS, did you attend a meeting about an issue facing your community or schools?

1. Yes

2. No

3. I don't know

Question 13: Many people say they have less time these days to do volunteer work. What about you, were you able to devote any time to volunteer work in the last 12 months or did you not do so?

1. Yes

2. No

3. I don't know

Question 14: Many people are finding it more difficult to make contributions to church or charity as much as they used to. How about you - were you able to contribute any money to church or charity in the past 12 months?

1. Yes

2. No

3. I don't know

Question 15: Did you vote for a candidate for President in the 2016 general election?

1. Yes

2. No

3. Was not eligible

4. Don't know

Question 16: Did you vote in the most recent election (primary election 2017) held in the area where you live?

1. Yes

2. No

3. Was not eligible

4. Don't know 
Question 17: Do you serve as an officer or committee member in any local organization? This includes on-campus organizations.

1. Yes

2. No

3. I don't know

Question 18: Are you a member of an organization such as hobby clubs, sports teams, community groups, groups working on political issues? This includes both on and off campus organizations.

1. Yes

2. No

3. I don't know

Question 19: During the past 12 months, have you worked with other people to deal with some issue facing your community?

1. Yes, I have done this in the past 12 months

2. No, I have not done this

3. I don't know

Question 20: Are you a member of a local church, synagogue, or other religious or spiritual community?

1. Yes

2. No

3. I don't know

Question 21: How often do you attend religious services?

1. Every week (or more often)

2. Almost every week

3. Once or twice a month

4. A few times per year

5. Less often than that

Question 22: Do you participate in church activities other than attending services?

1. Yes

2. No

3. I don't know

Question 23: During the past 12 months, have you ever given money to a religious organization, or have you not done this in the past 12 months?

1. Yes, I have done this in past 12 months

2. No, I have not done this in the past 12 months

3. I don't know

Question 24: How often have you had friends over to your home, apartment or dorm room in the past 12 months?

1. Never did this 
2. Once

3. A few times

4. 2-4 times

5. 5-9 times

6. About once a month on average

7. Twice a month

8. About once a week on average

9. More than once a week

Question 25: How often have you visited a friend's home, apartment or dorm room in the past 12 months?

1. Never did this

2. Once

3. A few times

4. 2-4 times

5. 5-9 times

6. About once a month on average

7. Twice a month

8. About once a week on average

9. More than once a week

Question 26: How often did you go out with friends in the last 12 months?

1. Never did this

2. Once

3. A few times

4. 2-4 times

5. 5-9 times

6. About once a month on average

7. Twice a month

8. About once a week on average

9. More than once a week

Question 27: How often can you trust the federal government in Washington to do what is right?

1. Always

2. Most of the time

3. About half the time

4. Some of the time

5. Never

Question 28: How much of the time do you think you can trust the local government to do what is right?

1. Always

2. Most of the time

3. About half the time

4. Some of the time

5. Never 
Question 29: How much of the time do you think you can trust the police in your local community?

1. Always

2. Most of the time

3. About half the time

4. Some of the time

5. Never

Question 30: How often can people be trusted?

1. Always

2. Most of the time

3. About half the time

4. Some of the time

5. Never

Question 31: How often can you trust someone of a different race than you?

1. Always

2. Most of the time

3. About half the time

4. Some of the time

5. Never

Question 32: How often can you trust someone in your neighborhood or on campus residential community?

1. Always

2. Most of the time

3. About half the time

4. Some of the time

5. Never

\section{Bridging and Bonding Social Capital Questions:}

Respondents could select the following responses to these questions:

1. Strongly agree

2. Somewhat agree

3. Neither agree nor disagree

4. Somewhat disagree

5. Strongly disagree

Question 1: Interacting with people makes me interested in things that happen outside of my town.

Question 2: Interacting with people makes me want to try new things.

Question 3: Interacting with people makes me interested in what people unlike me are thinking. Question 4: Talking with people make me curious about other places in the world. Question 5: Interacting with people makes me feel like part of a larger community. Question 6: Interacting with people makes me feel connected to the bigger picture. 
Question 7: Interacting with people reminds me that everyone in the world is connected.

Question 8: I am willing to spend time to support general community activities.

Question 9: Interacting with people give me new people to talk to.

Question 10: I come in contact with new people all of the time.

Question 11: There are several people I trust to help solve my problems.

Question 12: There is someone I can turn to for advice about making very important decisions.

Question 13: There is no one that I feel comfortable talking to about intimate personal problems.

Question 14: When I feel lonely, there are several people I can talk to.

Question 15: If I needed an emergency loan of \$500, I know someone I can turn to.

Question 16: The people I interact with would put their reputation on the line for me.

Question 17: The people I interact with would be good job references for me.

Question 18: The people I interact with would share their last dollar with me.

Question 19: I do not know people well enough to get them to do anything important.

Question 20: The people I interact with would help me fight an injustice. 


\section{APPENDIX C -}

Developing Social Capital and Empathy Using Virtual Reality Questionnaire

\section{Demographic Questions:}

Question 1: What is your gender?

1. Male

2. Female

3. Decline to state

Question 2: What is your age?

1. 18

2. 19

3. 20

4. 21

5. 22

6. 23

7. 24

8. 25

9. 26 or greater

Question 3: Please choose one or more races that you consider yourself to be:

- white;

- black or African-American;

- American Indian or Alaska Native;

- Asian; or

- Native Hawaiian or other Pacific Islander?

1. White

2. Black or African-American

3. American Indian or Alaska Native

4. Asian

5. Native Hawaiian or other Pacific Islander

Question 4: Are you Spanish, Hispanic, or Latino?

1. Yes

2. No

Question 5: What state do you reside in, when not attending college?

1. Alabama

2. Alaska

3. Arizona

4. Arkansas

5. California

6. Colorado

7. Connecticut

8. Delaware

9. District of Columbia 
10. Florida

11. Georgia

12. Hawaii

13. Idaho

14. Illinois

15. Indiana

16. Iowa

17. Kansas

18. Kentucky

19. Louisiana

20. Maine

21. Maryland

22. Massachusetts

23. Michigan

24. Minnesota

25. Mississippi

26. Missouri

27. Montana

28. Nebraska

29. Nevada

30. New Hampshire

31. New Jersey

32. New Mexico

33. New York

34. North Carolina

35. North Dakota

36. Ohio

37. Oklahoma

38. Oregon

39. Pennsylvania

40. Rhode Island

41. South Carolina

42. South Dakota

43. Tennessee

44. Texas

45. Utah

46. Vermont

47. Virginia

48. Washington

49. West Virginia

50. Wisconsin

51. Wyoming

52. I do not reside in the United States

Question 6: How would you describe your social class? Are you in the lower class, the working class, lower middle class, upper middle class, or the upper class? 
1. Lower class or poor

2. Working class

3. Lower middle class

4. Upper middle class

5. Upper class

Question 7: How many credit hours have you earned towards your bachelor's degree?

1. $0-28$ hours

2. $29-58$ hours

3. $59-88$ hours

4. $89+$ hours

Question 8: What is your overall GPA?

1. $4.0-3.5$

2. $3.49-3.0$

3. $2.99-2.5$

4. $2.49-2.0$

5. 1.9 and below

Question 9: What is your current major?

1. Political Science

2. International Studies

3. Other

Question 10: If you selected other, please identify your major in the field below.

(Open-Ended)

Question 11a: Will you use virtual reality goggles as part of your POLS 260 class? (PRE-TEST)

1. Yes

2. No

Question 11b: Did you use virtual reality goggles as part of your POLS 260 class? (POST-TEST)

1. Yes

2. No

Question 12: Approximately how many of the videos did you watch using virtual reality goggles? (POST-TEST)

1. All or most of the assigned videos

2. Over half of the assigned videos

3. Less than half of the assigned videos

4. Only several of the assigned videos

5. I did not watch any of the videos

\section{Post-Test Open-Ended Questions:}

These questions were only displayed to respondents who indicated a "YES" to question 11B about using virtual reality in class. 
Question 1. What was the best part of the virtual reality experience?

Question 2. What was the worst part of the virtual reality experience?

Question 3. What did you learn by watching the virtual reality videos?

\section{Pre and Post Test Bridging and Bonding Social Capital Questions:}

Respondents could select the following responses to these questions:

1. Strongly agree

2. Somewhat agree

3. Neither agree nor disagree

4. Somewhat disagree

5. Strongly disagree

Question 1: Interacting with people makes me interested in things that happen outside of my town.

Question 2: Interacting with people makes me want to try new things.

Question 3: Interacting with people makes me interested in what people unlike me are thinking. Question 4: Talking with people make me curious about other places in the world.

Question 5: Interacting with people makes me feel like part of a larger community. Question 6: Interacting with people makes me feel connected to the bigger picture. Question 7: Interacting with people reminds me that everyone in the world is connected. Question 8: I am willing to spend time to support general community activities. Question 9: Interacting with people give me new people to talk to. Question 10: I come in contact with new people all of the time. Question 11: There are several people I trust to help solve my problems. Question 12: There is someone I can turn to for advice about making very important decisions. Question 13: There is no one that I feel comfortable talking to about intimate personal problems. Question 14: When I feel lonely, there are several people I can talk to.

Question 15: If I needed an emergency loan of $\$ 500$, I know someone I can turn to. Question 16: The people I interact with would put their reputation on the line for me. Question 17: The people I interact with would be good job references for me. Question 18: The people I interact with would share their last dollar with me. Question 19: I do not know people well enough to get them to do anything important. Question 20: The people I interact with would help me fight an injustice.

\section{Pre ant Post Test Empathy Questions:}

Respondents could select the following responses to these questions:

1. Strongly agree

2. Slightly agree

3. Slightly disagree

4. Strongly disagree

Question1: I sometimes find it difficult to see things from the "other guy's" point of view. 
Question 2: I am usually objective when I watch a film or play, and I don't often get completely caught up in it.

Question 3: I try to look at everybody's side of a disagreement before I make a decision.

Question 4: I sometimes try to understand my friends better by imagining how things look from their perspective.

Question 5: When I am upset at someone, I usually try to "put myself in his shoes" for a while. Question 6: Before criticizing somebody, I try to imagine how I would feel if I was in their place. Question 7: I often get emotionally involved with my friends' problems.

Question 8: I am inclined to get nervous when others around me seem to be nervous.

Question 9: People I am with have a strong influence on my mood.

Question 10: It affects me very much when one of my friends seems upset.

Question 11: I often get deeply involved with the feelings of a character in a film, play, or novel. Question 12: I get very upset when I see someone cry.

Question 13: I am happy when I am with a cheerful group and sad when the others are glum.

Question 14: It worries me when others are worrying and panicky.

Question 15: I can easily tell if someone else wants to enter a conversation.

Question 16: I can pick up quickly if someone says one thing but means another.

Question 17: It is hard for me to see why some things upset people so much.

Question 18: I find it easy to put myself in somebody else's shoes.

Question 19: I am good at predicting how someone will feel.

Question 20: I am quick to spot when someone in a group is feeling awkward or uncomfortable. Question 21: Other people tell me I am good at understanding how they are feeling and what they are thinking.

Question 22: I can easily tell if someone else is interested or bored with what I am saying.

Question 23: Friends talk to me about their problems as they say that I am very understanding.

Question 24: I can sense if I am intruding, even if the other person does not tell me.

Question 25: I can easily work out what another person might want to talk about.

Question 26: I can tell if someone is masking their true emotion.

Question 27: I am good at predicting what someone will do.

Question 28: I can usually appreciate the other person's viewpoint, even if I do not agree with it.

Question 29: I usually stay emotionally detached when watching a film.

Question 30: I always try to consider the other fellow's feelings before I do something.

Question 31: Before I do something I try to consider how my friends will react to it. 


\section{APPENDIX D -}

Synopsis of Virtual Reality Videos Assigned (running time and VR application platform noted in parenthesis)

Clouds Over Sidra (8:34 running time) - Clouds Over Sidra is a 2015 virtual reality film about the Syrian refugee crisis. The film features a twelve year old in the Za'atari camp in Jordan, home to 84,000 Syrian refugees. It follows her throughout the day from her family's tent, to school, to a bakery, to a computer lab and the camp football pitch. It is the first film shot in virtual reality for the United Nations.

Sylvia's Story (2:54, UNICEF 360) - Sylvia's dream for her future is shadowed by daily concerns for her safety. This is a story of a 14-year old's strength and hope, representing the millions of girls whose situation is just as dire, or worse.

Giant (5:00, Within) - Set within the basement of a home within an unnamed war zone, Giant gives viewers a glimpse into a world that is a harsh reality for some and a virtual awakening for others. In it, you witness a couple consoling their daughter while bombs blast nearby buildings and threaten their existence.

Pilgrimage (4:38, NYT) - A 21st century journey to Mecca and Medina.

The Fight for Falluja (11:08, NYT) - embed with Iraqi forces as they retake a city from ISIS and experience the battle's aftermath.

My Mother's Wing - (8:00, Within) - In Gaza, foundations are built, destroyed, and built again. This VR experience follows a mother attempting to cope with the loss of her two children, victims of a shelling attack on her children's school.

Indefinite (14:48, NYT) - immigrants facing a future of indefinite detention. Step into their world.

10 Shots Across the Border (7:45, NYT) - see why the killing of a Mexican 16-year-odl raises troubling questions about the U.S. Border Patrol.

The Land of Salt and Fire (6:09, NYT) - visit the hottest place on Earth, where active geothermal zones turn into a landscape of psychedelic colors.

I Dream of an Empty Ward (6:05, Rotary) -Archie Panjabi tells the story of Alokita, a young girl living in India and one of the last generation of children to be affected by polio.

Waves of Grace (10:00, Within) - This is the story of Decontee Davis, an Ebola survivor who uses her immunity to care for orphaned children in her Liberian village. Liberia has endured the largest Ebola outbreak in history. As communities rebuild, Decontee and others seek healing through faith. 
We Who Remain (15:00, NYT) - a relentless war persists in the Nuba Mountains of Sudan. Thousands of people have been forced to flee. This is the story of those who remain.

See the Difference Water Can Make (3:02, VRScout) - Getting a glass of water is a simple task for many of us, but for millions around the world, access to water is a much more complicated and time-consuming problem. And for some women and children, carrying water is their life's purpose, sometimes making as many as 8 trips a day to the nearest water source.

The Food Drop (1:44, NYT) -War has driven 30 million children from their homes. These are the stories of three of them.

The Source (9:00, Within) - 13-year-old Selam used to walk miles each day to bring water to her family, struggling to make time for her schoolwork too. Experience the transformation of her Ethiopian community as a well bearing fresh water is dug for the first time.

Lochap's Story (2:00, UNICEF 360) - Lochap's village has just received a new water pump but they have nothing to eat. Join UNICEF on a virtual expedition to a very remote area of Uganda to follow a 12-year-old boy in his daily struggles.

Ground Beneath Her (6:26, UNDP) - Ground Beneath Her is a virtual reality film that showcases the struggle of 14-year-old Sabita. More than a year after the earthquake, Sabita must balance the pain of picking up the pieces after the devastating quake and fulfilling the everyday duties of a fractured home, all while trying to keep her dreams for her future alive. 